\title{
Targeted degradation of the oncogenic phosphatase SHP2
}

\author{
Vidyasiri Vemulapalli ${ }^{1,2}$, Katherine A. Donovan², Tom C.M. Seegar ${ }^{3}$, Julia M. Rogers ${ }^{1}$, \\ Munhyung Bae ${ }^{1}$, Ryan J. Lumpkin², Ruili Cao ${ }^{1}$, Matthew T. Henke ${ }^{1}$, Eric S. Fischer ${ }^{1,2}$, Gregory \\ D. Cuny ${ }^{4}$, Stephen C. Blacklow ${ }^{1,2 *}$
}

${ }^{1}$ Department of Biological Chemistry and Molecular Pharmacology, Harvard Medical School, Boston MA, 02115

${ }^{2}$ Department of Cancer Biology, Dana Farber Cancer Institute, Boston MA 02215

${ }^{3}$ Department of Molecular Genetics, Biochemistry and Microbiology, University of Cincinnati College of Medicine, Cincinnati $\mathrm{OH}, 45267$

${ }^{4}$ Department of Pharmacological and Pharmaceutical Sciences, University of Houston, Houston, TX 77204

*To whom correspondence should be addressed: Stephen blacklow@hms.harvard.edu 


\section{Abstract}

SHP2 is a protein tyrosine phosphatase that plays a critical role in the full activation of the Ras/MAPK pathway upon stimulation of receptor tyrosine kinases (RTKs), which are frequently amplified or mutationally activated in human cancer. In addition, activating mutations in SHP2 result in developmental disorders and hematologic malignancies. Several allosteric inhibitors have been developed for SHP2 and are currently in clinical trials. Here, we report the development and evaluation of a SHP2 PROTAC created by conjugating RMC-4550 with pomalidomide using a PEG linker. This molecule is highly selective for SHP2, induces degradation of SHP2 in leukemic cells at sub-micromolar concentration, inhibits MAPK signaling, and suppresses cancer cell growth. SHP2 PROTACs serve as an alternative strategy for targeting ERK-dependent cancers and are useful tools alongside allosteric inhibitors for dissecting the mechanisms by which SHP2 exerts its oncogenic activity. 
The proto-oncogene PTPN11 encodes a cytoplasmic protein tyrosine phosphatase, SHP2, which is required for normal development. SHP2 acts downstream of multiple receptor tyrosine kinases (RTKs) to exert sustained activation of the RAS-MAPK signaling cascade. The first oncogenic phosphatase to be identified, SHP2 is dysregulated in multiple human diseases, where germline mutations cause the developmental disorders of Noonan and LEOPARD syndromes. Somatic mutations of SHP2 are found in about $35 \%$ of cases of juvenile myelomonocytic leukemia (JMML), and are seen recurrently in myelodysplastic syndrome, ALL, AML, and even in solid tumors ${ }^{1,2}$. Oncogenic mutations in SHP2 destabilize the "off" or "autoinhibited" state of the enzyme and boost basal activity through shifting the conformational equilibrium towards a more open state ${ }^{3}$, which leads to uncontrolled MAPK activation. Reduction of SHP2 activity through genetic knockdown or allosteric inhibition suppresses RAS-ERK signalling and inhibits tumor growth, validating SHP2 as a target for cancer therapy ${ }^{4}$. Moreover, because SHP2 lies downstream of the T cell immunoinhibitory receptor PD-1, SHP2 inhibition may also be a viable strategy for cancer immunotherapy in combination with PD-1 blockade or with other immunomodulatory agents ${ }^{5-7}$.

Structurally, SHP2 is composed of two tandem Src homology 2 (SH2) domains, N-SH2 and $\mathrm{C}-\mathrm{SH} 2$, followed by a catalytic protein tyrosine phosphatase (PTP) domain and an unstructured C-terminal tail. In the basal state, the $\mathrm{N}-\mathrm{SH} 2$ domain packs against and sterically occludes the active site of the PTP domain by inserting a loop into the cleft that inhibits substrate access. Upon engagement of the $\mathrm{N}-\mathrm{SH} 2$ and $\mathrm{C}-\mathrm{SH} 2$ domains of SHP2 with tyrosinephosphorylated signaling proteins, SHP2 activity is induced, presumably due to an induced conformational opening that alleviates $\mathrm{N}-\mathrm{SH} 2$ autoinhibition of the PTP domain active site ${ }^{8}$. Cancer mutations typically occur at the interface between the N-SH2 and PTP domains and, in most cases, activate the phosphatase ${ }^{8}$. 
Given the importance of SHP2 in cancer therapy, there have been a number of efforts to develop SHP2-selective inhibitors. Early reports described active site-directed competitive inhibitors that had poor selectivity ${ }^{9,10}$. More recently, research groups at Novartis and Revolution Medicines developed allosteric inhibitors that are highly selective for SHP2, called SHP099 ${ }^{4,11}$ and RMC4550 ${ }^{12}$, which were both shown to be effective tool compounds with nanomolar potency and pre-clinical activity in RTK- and RAS-driven cancers ${ }^{4,12}$. Currently, several SHP2 allosteric inhibitors (TNO155, JAB-3312, RMC-4630, RLY-1971, ERAS-601) are in phase I/II clinical trials for the treatment of advanced or metastatic solid tumors.

Although allosteric SHP2 inhibitors show clinical promise, recent preclinical studies highlight the potential for the emergence of non-mutational mechanisms of resistance ${ }^{13}$. By acutely depleting the target protein, proteolysis targeting chimeras (PROTACs) have the potential to overcome such resistance mechanisms. By degrading the target protein, they have the additional benefit of eliminating any residual activity of the target protein associated with the inhibitor-bound state.

Here, we report the development and characterization of a proteolysis targeting chimera (PROTAC) highly selective for degradation of SHP2. Our lead compound consists of a SHP2binding warhead (RMC-4550) tethered to an IMiD (immunomodulatory drug) derivative using a PEG linker. By increasing the linker length of our first generation PROTAC, we identified a lead compound that carries out highly selective SHP2 degradation with a low nanomolar $\mathrm{DC}_{50}$, suppresses MAPK signaling, and inhibits cancer cell growth. This SHP2-targeting PROTAC will be a valuable tool for acute depletion of SHP2 in functional studies and will be a starting point for further development of a SHP2-targeting PROTAC therapeutic.

\section{Materials and Methods}


Chemical Synthesis. The compounds reported in this manuscript were synthesized as described below.

\section{Scheme 1}<smiles>NC1CCC(=O)NC1=O</smiles><smiles>O=C1CCC(N2C(=O)c3cccc(O)c3C2=O)C(=O)N1</smiles>
1. $\mathrm{BrCH}_{2} \mathrm{CO}_{2} \mathrm{tBu}$ $\mathrm{K}_{2} \mathrm{CO}_{3}$, DMF $20{ }^{\circ} \mathrm{C}, 18 \mathrm{~h}$
2. $\mathrm{HCl}, \mathrm{EtOAc}$ $10^{\circ} \mathrm{C}, 18 \mathrm{~h}$<smiles>O=C(O)COc1cccc2c1C(=O)N(C1CCC(=O)NC1=O)C2=O</smiles>

Intermediate 2

\section{2-(2,6-Dioxopiperidin-3-yl)-4-hydroxyisoindoline-1,3-dione (S1-1): A mixture of 3-}

aminopiperidine-2,6-dione (19.2 g, 116 mmol, 1.00 eq), 4-hydroxyisobenzofuran-1,3-dione (21.0 g, $128 \mathrm{mmol}, 1.10 \mathrm{eq})$ and KOAc (34.3 g, $349 \mathrm{mmol}, 3.00 \mathrm{eq})$ in AcOH (200 mL). The mixture was stirred at $120^{\circ} \mathrm{C}$ for $3 \mathrm{~h}$. The reaction mixture was concentrated under reduced pressure to remove solvent. The residue was diluted with water $(250 \mathrm{~mL})$, filtered, washed with water, and concentrated under reduced pressure to give 2-(2,6-dioxopiperidin-3-yl)-4-hydroxyisoindoline1,3-dione (28.0 g, $101 \mathrm{mmol}, 86.7 \%$ yield, 98.8\% purity) was obtained as a gray solid.

\section{2-((2-(2,6-Dioxopiperidin-3-yl)-1,3-dioxoisoindolin-4-yl)oxy)acetic acid (Intermediate 2): To}

a solution of 2-(2,6-dioxopiperidin-3-yl)-4-hydroxyisoindoline-1,3-dione (28.0 g, $102 \mathrm{mmol}$, $1.00 \mathrm{eq})$ in DMF (200 mL) was added tert-butyl 2-bromoacetate $(19.9 \mathrm{~g}, 102 \mathrm{mmol}, 15.1 \mathrm{~mL}$, $1.00 \mathrm{eq})$, KI (1.69 g, $10.2 \mathrm{mmol}, 0.100 \mathrm{eq})$ and $\mathrm{K}_{2} \mathrm{CO}_{3}(21.2 \mathrm{~g}, 153 \mathrm{mmol}, 1.50 \mathrm{eq})$. The mixture was stirred at $20^{\circ} \mathrm{C}$ for $18 \mathrm{~h}$. The reaction mixture was diluted with water $(250 \mathrm{~mL})$ and 
extracted with EtOAc $(150 \mathrm{~mL} \times 3)$. The combined organic layers were washed with saturated $\mathrm{NaCl}(200 \mathrm{~mL})$, dried over anhydrous $\mathrm{Na}_{2} \mathrm{SO}_{4}$, filtered and concentrated under reduced pressure to give a residue. The crude product was triturated with MTBE $(200 \mathrm{~mL})$ at $10{ }^{\circ} \mathrm{C}$ for $3 \mathrm{~h}$, and then the product was triturated with n-heptane $(100 \mathrm{~mL})$ at $105^{\circ} \mathrm{C}$ for $3 \mathrm{~h}$ to give the product tert-butyl 2-((2-(2,6-dioxopiperidin-3-yl)-1,3-dioxoisoindolin-4-yl)oxy)acetate (36.0 g, 90.1 mmol, $88.7 \%$ yield, $97.7 \%$ purity) as a white solid.

To a solution of tert-butyl 2-((2-(2,6-dioxopiperidin-3-yl)-1,3-dioxoisoindolin-4yl)oxy)acetate $(5.00 \mathrm{~g}, 12.9 \mathrm{mmol}, 1.00 \mathrm{eq})$ in EtOAc $(2.00 \mathrm{~mL})$ was added $\mathrm{HCl} / \mathrm{EtOAc}(4 \mathrm{M}$, $45.0 \mathrm{~mL}, 14.0 \mathrm{eq})$. The mixture was stirred at $10^{\circ} \mathrm{C}$ for $18 \mathrm{~h}$. The reaction mixture was concentrated under reduced pressure to remove the EtOAc. The crude product was triturated with MTBE $(200 \mathrm{~mL})$ at $10{ }^{\circ} \mathrm{C}$ for $1 \mathrm{~h}$, filtered and concentrated under reduced pressure. To the solid was added deionized water $(100 \mathrm{~mL})$. The residual aqueous solution was lyophilized to give Intermediate 2 (4.00 g, $11.6 \mathrm{mmol}, 90.3 \%$ yield, 96.6\% purity) as a white solid. 


\section{Scheme 2}

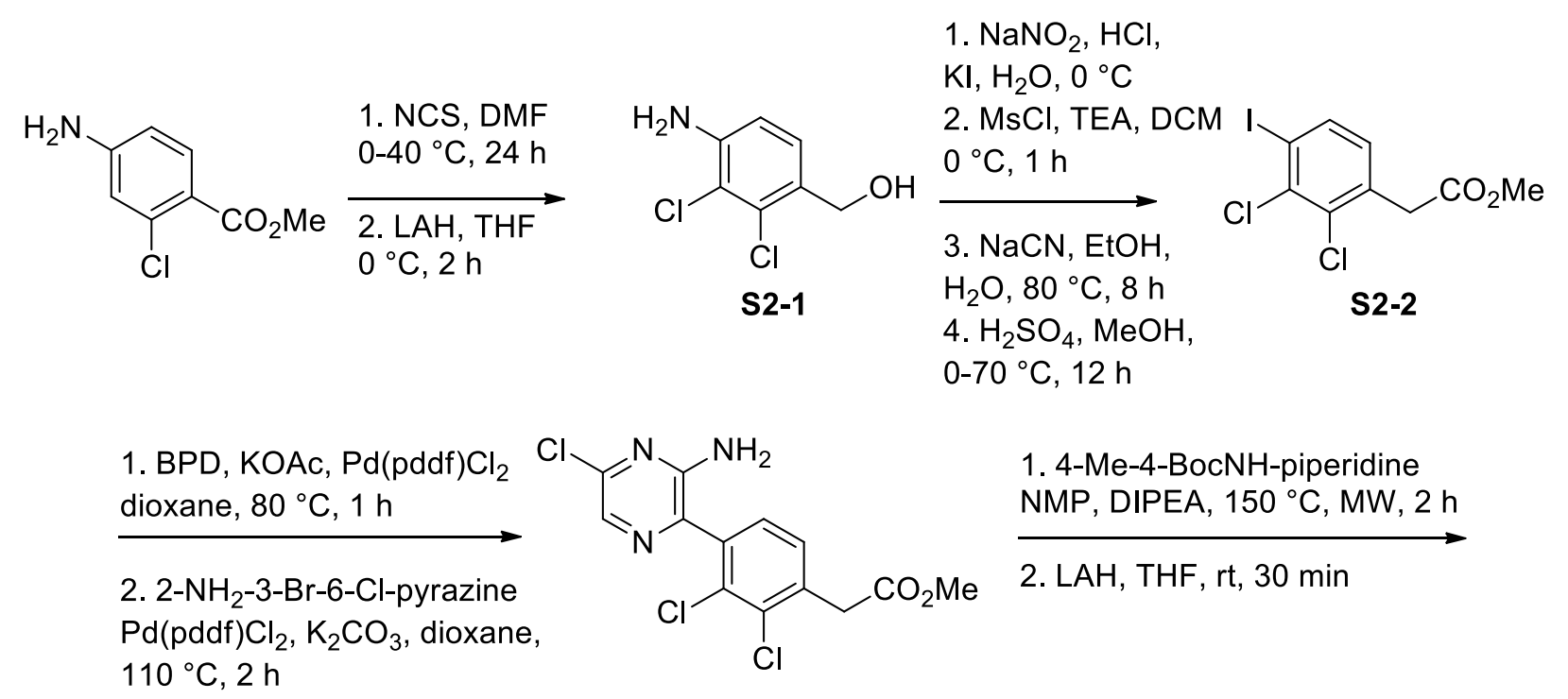

S2-3<smiles>CCOC(=O)NC(C)(C)C</smiles>

Intermediate 1

(4-Amino-2,3-dichlorophenyl)methanol (S2-1): To a solution of methyl 4-amino-2-

chlorobenzoate $(72.0 \mathrm{~g}, 387 \mathrm{mmol}, 1.00 \mathrm{eq})$ in DMF (360 mL) was added NCS (55.0 g, 411

mmol, 1.06 eq) at $0{ }^{\circ} \mathrm{C}$ and the mixture was stirred at $40{ }^{\circ} \mathrm{C}$ for $24 \mathrm{~h}$. The reaction mixture was poured into water $(500 \mathrm{~mL})$ and a precipitate was formed, filtered and collected. The crude product was purified by re-crystallization from $\mathrm{EtOH}(250 \mathrm{~mL})$ at $80{ }^{\circ} \mathrm{C}$ to give methyl 4-amino2,3-dichlorobenzoate (48.0 $\mathrm{g}, 56.2 \%$ yield) as a yellow solid.

To a solution of 4-amino-2,3-dichlorobenzoate (50.0 g, $227 \mathrm{mmol}, 1.00 \mathrm{eq})$ in THF (500 mL) was added $\mathrm{LiAlH}_{4}(18.0 \mathrm{~g}, 474 \mathrm{mmol}, 2.09 \mathrm{eq})$ at $0{ }^{\circ} \mathrm{C}$ and the mixture was stirred at $0{ }^{\circ} \mathrm{C}$ for $2 \mathrm{~h}$. To the mixture was slowly added water $(23 \mathrm{~mL}), 15 \% \mathrm{NaOH}(23 \mathrm{~mL})$, and $\mathrm{MgSO}_{4}$ 
$(150 \mathrm{~g})$ at $0^{\circ} \mathrm{C}$, the mixture was stirred at $10^{\circ} \mathrm{C}$ for $15 \mathrm{~min}$, filtered and concentrated under reduced pressure to give a residue. The mixture was triturated with petroleum ether/EtOAc (6/1, $70 \mathrm{~mL})$ at $15{ }^{\circ} \mathrm{C}$ for $12 \mathrm{~h}$ to give $\mathbf{S 2 - 1}(36.0 \mathrm{~g}, 75.9 \%$ yield, $92.1 \%$ purity) as a light yellow solid.

Methyl 2-(2,3-dichloro-4-iodophenyl)acetate (S2-2): To a solution of S2-1 (34.0 g, 177 mmol, $1.00 \mathrm{eq})$ in $\mathrm{H}_{2} \mathrm{O}(340 \mathrm{~mL})$ and $\mathrm{HCl}(12 \mathrm{M}, 340 \mathrm{~mL}, 23.0 \mathrm{eq})$ was added a solution of $\mathrm{NaNO}_{2}(18.3 \mathrm{~g}, 265 \mathrm{mmol}, 1.50 \mathrm{eq})$ in water $(34 \mathrm{~mL})$ drop-wise at $0^{\circ} \mathrm{C}$. The mixture was stirred at $0{ }^{\circ} \mathrm{C}$ for $30 \mathrm{~min}$. Then a solution of $\mathrm{KI}(146 \mathrm{~g}, 885 \mathrm{mmol}, 5.00 \mathrm{eq})$ in water $(340 \mathrm{~mL})$ was added drop-wise at $0^{\circ} \mathrm{C}$ and the resulting mixture was stirred at $0{ }^{\circ} \mathrm{C}$ for $30 \mathrm{~min}$. The mixture was extracted with EtOAc $(600 \mathrm{~mL} \times 3)$. The combined organic phase was washed with brine and dried over anhydrous $\mathrm{Na}_{2} \mathrm{SO}_{4}$, filtered and concentrated under vacuum to give a residue. The residue was purified by column chromatography $\left(\mathrm{SiO}_{2}\right.$, petroleum ether/EtOAc $=$ $\left.100 / 1 \sim 20 / 1, \mathrm{R}_{\mathrm{f}}=0.56\right)$ to give (2,3-dichloro-4-iodophenyl)methanol (25.0 g, 46.6\% yield) as a yellow solid.

To a solution of (2,3-dichloro-4-iodophenyl)methanol (26.0 g, $85.8 \mathrm{mmol}, 1.00 \mathrm{eq})$ in DCM (500 mL) and TEA (26.0 g, $257 \mathrm{mmol}, 35.8 \mathrm{~mL}, 3.00 \mathrm{eq})$ was added MsCl (13.2 g, 115 mmol, $8.95 \mathrm{~mL}, 1.35 \mathrm{eq}$ ) at $0{ }^{\circ} \mathrm{C}$. The mixture was stirred at $0{ }^{\circ} \mathrm{C}$ for $1 \mathrm{~h}$. The mixture was washed with brine $(300 \mathrm{~mL} \times 3)$ and dried over anhydrous $\mathrm{Na}_{2} \mathrm{SO}_{4}$, filtered and concentrated under vacuum to give the corresponding mesylate $(31.0 \mathrm{~g}, 94.7 \%$ yield $)$ as a brown solid. To this material (31.0 g, $81.3 \mathrm{mmol}, 1.00 \mathrm{eq})$ in $\mathrm{EtOH}(620 \mathrm{~mL})$ was added a solution of $\mathrm{NaCN}$ $(6.04 \mathrm{~g}, 123 \mathrm{mmol}, 1.51 \mathrm{eq})$ in water $(155 \mathrm{~mL})$. The mixture was stirred at $80{ }^{\circ} \mathrm{C}$ for $8 \mathrm{~h}$. The mixture was concentrated under vacuum to remove EtOH and diluted with water $(150 \mathrm{~mL})$, extracted with EtOAc $(100 \mathrm{~mL} \times 3)$. The combined organic phase was washed with brine $(200$ 
$\mathrm{mL})$ and dried over anhydrous $\mathrm{Na}_{2} \mathrm{SO}_{4}$, filtered and concentrated under vacuum to give 2-(2,3dichloro-4-iodophenyl)acetonitrile (18.0 g, 70.9\% yield) as a light yellow solid.

To a solution of 2-(2,3-dichloro-4-iodophenyl)acetonitrile (17.0 g, $54.5 \mathrm{mmol}, 1.00 \mathrm{eq})$ in $\mathrm{MeOH}(150 \mathrm{~mL})$ was added $\mathrm{H}_{2} \mathrm{SO}_{4}(88.3 \mathrm{~g}, 900 \mathrm{mmol}, 48.0 \mathrm{~mL}, 16.5 \mathrm{eq})$ at $0{ }^{\circ} \mathrm{C}$. The mixture was stirred at $70{ }^{\circ} \mathrm{C}$ for $12 \mathrm{~h}$. The reaction mixture was concentrated under reduced pressure to remove $\mathrm{MeOH}$. The residue was diluted with water $(150 \mathrm{~mL})$ and extracted with EtOAc (100 $\mathrm{mL} \times 2)$. The combined organic layers were washed with brine $(200 \mathrm{~mL})$, dried over anhydrous $\mathrm{Na}_{2} \mathrm{SO}_{4}$, filtered and concentrated under reduced pressure to give $\mathbf{S 2 - 2}$ (15.0 g, 79.7\% yield) as a light yellow solid.

Methyl 2-(4-(3-amino-5-chloropyrazin-2-yl)-2,3-dichlorophenyl)acetate (S2-3): A mixture of S2-2 (6.00 g, $17.3 \mathrm{mmol}, 1.00 \mathrm{eq})$, BPD (4.64 g, $18.2 \mathrm{mmol}, 1.05 \mathrm{eq})$, AcOK (8.54 g, $86.9 \mathrm{mmol}$, $5.00 \mathrm{eq})$ and $\mathrm{Pd}(\mathrm{dppf}) \mathrm{Cl}_{2}\left(600 \mathrm{mg}, 920 \mathrm{umol}, 5.29 \times 10^{-2} \mathrm{eq}\right)$ in 1,4-dioxane $(60 \mathrm{~mL})$ was stirred at $80{ }^{\circ} \mathrm{C}$ for $1 \mathrm{~h}$ under $\mathrm{N}_{2}$. The mixture was filtered and the filtrate was concentrated under vacuum to give a residue. The residue was purified by column chromatography $\left(\mathrm{SiO}_{2}\right.$, petroleum ether/EtOAc $\left.=30 / 1 \sim 10 / 1, \mathrm{R}_{\mathrm{f}}=0.54, \mathrm{I}_{2}\right)$ to give methyl 2-(2,3-dichloro-4-(4,4,5,5-tetramethyl1,3,2-dioxaborolan-2-yl)phenyl)acetate (5.50 g, crude) as light yellow oil.

A mixture of 3-bromo-6-chloropyrazin-2-amine (1.00 g, $4.80 \mathrm{mmol}, 1.00 \mathrm{eq})$, methyl 2(2,3-dichloro-4-(4,4,5,5-tetramethyl-1,3,2-dioxaborolan-2-yl)phenyl)acetate (4.97 g, $14.3 \mathrm{mmol}$, $3.00 \mathrm{eq}), \mathrm{Pd}(\mathrm{dppf}) \mathrm{Cl}_{2}(175 \mathrm{mg}, 239 \mathrm{umol}, 0.05 \mathrm{eq})$ and $\mathrm{K}_{2} \mathrm{CO}_{3}(663 \mathrm{mg}, 4.80 \mathrm{mmol}, 1.00 \mathrm{eq})$ in 1,4-dioxane $(40 \mathrm{~mL})$ was stirred at $110^{\circ} \mathrm{C}$ for $2 \mathrm{~h}$. The mixture was filtered through a pad of celite and the filtrate was concentrated under vacuum to give a residue. The residue was purified by column chromatography $\left(\mathrm{SiO}_{2}\right.$, petroleum ether/EtOAc $\left.=30 / 1 \sim 1 / 1, \mathrm{R}_{\mathrm{f}}=0.23\right)$ to give $\mathbf{S} 2-\mathbf{3}$ (900 mg, 51.3\% yield, 94.8\% purity) as a yellow solid. 


\section{Tert-butyl (1-(6-amino-5-(2,3-dichloro-4-(2-hydroxyethyl)phenyl)pyrazin-2-yl)-4-}

methylpiperidin-4-yl)carbamate (Intermediate 1): S2-3 (900 mg, $2.46 \mathrm{mmol}, 1.00 \mathrm{eq})$, tert-

butyl (4-methylpiperidin-4-yl)carbamate (800 mg, $3.73 \mathrm{mmol}, 1.52 \mathrm{eq})$ and DIPEA (1.59 g, 12.3 mmol, $2.14 \mathrm{~mL}, 5.00 \mathrm{eq})$ were taken up into a microwave tube in NMP $(10 \mathrm{~mL})$. The sealed tube was heated at $150{ }^{\circ} \mathrm{C}$ for $2 \mathrm{~h}$ under microwave. The mixture was diluted with water (30 $\mathrm{mL})$ and extracted with EtOAc $(30 \mathrm{~mL} \times 3)$. The combined organic phase was washed with brine $(50 \mathrm{~mL})$ and dried over anhydrous $\mathrm{Na}_{2} \mathrm{SO}_{4}$, filtered and concentrated under vacuum to give a residue. The residue was purified by column chromatography $\left(\mathrm{SiO}_{2}\right.$, petroleum ether/EtOAc $=$ $\left.10 / 1 \sim 1 / 1, \mathrm{R}_{\mathrm{f}}=0.33\right)$ to give methyl 2-(4-(3-amino-5-(4-((tert-butoxycarbonyl)amino)-4methylpiperidin-1-yl)pyrazin-2-yl)-2,3-dichlorophenyl)acetate (600 mg, 40.5\% yield, 87.3\% purity) as yellow oil.

To a solution of methyl 2-(4-(3-amino-5-(4-((tert-butoxycarbonyl)amino)-4methylpiperidin-1-yl)pyrazin-2-yl)-2,3-dichlorophenyl)acetate (600 mg, 998 umol, 1.00 eq) in THF (1.5 mL) was added $\mathrm{LiAlH}_{4}(78.5 \mathrm{mg}, 2.07 \mathrm{mmol}, 2.07 \mathrm{eq})$. The mixture was stirred at 20 ${ }^{\circ} \mathrm{C}$ for $0.5 \mathrm{~h}$. Next, $0.08 \mathrm{~mL}$ water and $0.08 \mathrm{~mL} 10 \%$ aqueous $\mathrm{NaOH}$ was added to the mixture at $0{ }^{\circ} \mathrm{C}$, followed by addition $0.24 \mathrm{~mL}$ water and $3.00 \mathrm{~g} \mathrm{MgSO}_{4}$. The mixture was stirred at $15{ }^{\circ} \mathrm{C}$ for $15 \mathrm{~min}$, filtered and the filtrate was concentrated under vacuum to give a residue. The residue was purified by column chromatography $\left(\mathrm{SiO}_{2}\right.$, petroleum ether/EtOAc $=10 / 1 \sim 1 / 1, \mathrm{R}_{\mathrm{f}}=$ 0.23 ) to give Intermediate 1 (400 $\mathrm{mg}, 74.0 \%$ yield, $91.8 \%$ purity) as yellow oil. 


\section{Scheme 3}

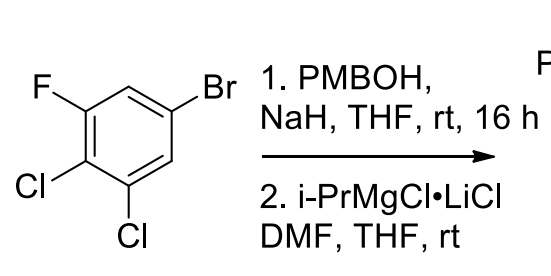

1. $\mathrm{H}_{2} \mathrm{SO}_{4}, \mathrm{MeOH}$
$80^{\circ} \mathrm{C}, 36 \mathrm{~h}$

2. $\mathrm{Tf}_{2} \mathrm{O}, \mathrm{py}, \mathrm{rt}, 1 \mathrm{~h}$

3. BPD, KOAc, $\mathrm{Pd}(\mathrm{dppf}) \mathrm{Cl}_{2}$ $100{ }^{\circ} \mathrm{C}, 2 \mathrm{~h}$<smiles>[R2]c1cc(B2OC(C)(C)C(C)(C)O2)c(Cl)c(Cl)c1[R]</smiles>

S3-3a $\mathrm{R}_{1}=\mathrm{CH}_{2} \mathrm{CO}_{2} \mathrm{Me}, \mathrm{R}_{2}=\mathrm{H}$

S3-3b $R_{1}=H, R_{2}=O H$
1. $\mathrm{NaBH}_{4}, \mathrm{THF}$

$15^{\circ} \mathrm{C}, 1 \mathrm{~h}$

2. $\mathrm{MsCl}, \mathrm{TEA}$,

$\mathrm{DCM}, 0^{\circ} \mathrm{C}, 1 \mathrm{~h}$

3. $\mathrm{NaCN}, \mathrm{EtOH}$

$80^{\circ} \mathrm{C}, 8 \mathrm{~h}$<smiles>CCCCOc1cc(CC#N)cc(Cl)c1Cl</smiles>

S3-2

1. 4-Me-4-BocNH $\mathrm{H}_{2}$-piperidine NMP, DIPEA, $150^{\circ} \mathrm{C}, \mathrm{MW}, 2 \mathrm{~h}$

2-NH $\mathrm{N}_{2}-3-\mathrm{Br}-6-\mathrm{Cl}$-pyrazine $\mathrm{Pd}(\mathrm{dppf}) \mathrm{Cl}_{2}, \mathrm{~K}_{3} \mathrm{PO}_{4}$,

dioxane, $\mathrm{H}_{2} \mathrm{O}, 110^{\circ} \mathrm{C}, 2 \mathrm{~h}$<smiles>[R]c1cc(-c2ncc(Cl)nc2N)c(Cl)c(Cl)c1[R2]</smiles>

S3-4a R $1=\mathrm{CH}_{2} \mathrm{CO}_{2} \mathrm{Me}, \mathrm{R}_{2}=\mathrm{H}$ S3-4b R $=\mathrm{H}, \mathrm{R}_{2}=\mathrm{OH}$<smiles>[R2]c1cc(-c2ncc(N3CCC(C)(NC(C)(C)C)CC3)nc2N)c(Cl)c(Cl)c1[R2]</smiles>

Intermediate $3 \mathrm{R}_{1}=\mathrm{CH}_{2} \mathrm{CH}_{2} \mathrm{OH}, \mathrm{R}_{2}=\mathrm{H}$

Intermediate $4 \mathrm{R}_{1}=\mathrm{H}, \mathrm{R}_{2}=\mathrm{OH}$

\section{3,4-Dichloro-5-((4-methoxybenzyl)oxy)benzaldehyde (S3-1): To a solution of 4-}

methoxybenzyl alcohol (PMBOH, $30.5 \mathrm{~g}, 221 \mathrm{mmol}, 27.5 \mathrm{~mL}, 1.20 \mathrm{eq})$ in THF (450 mL) was added $\mathrm{NaH}(10.3 \mathrm{~g}, 258 \mathrm{mmol}, 60 \%$ purity, $1.40 \mathrm{eq})$ at $25^{\circ} \mathrm{C}$. The mixture was stirred at $25^{\circ} \mathrm{C}$ for $0.5 \mathrm{~h}$. Then 5-bromo-1,2-dichloro-3-fluorobenzene ( $45.0 \mathrm{~g}, 184 \mathrm{mmol}, 1.00 \mathrm{eq})$ was added and the resulting mixture was stirred at $25^{\circ} \mathrm{C}$ for $16 \mathrm{~h}$. The mixture was quenched with $600 \mathrm{~mL}$ saturated aqueous $\mathrm{NH}_{4} \mathrm{Cl}$ and extracted with EtOAc $(500 \mathrm{~mL} \times 3)$. The combined organic phase was washed with $800 \mathrm{~mL}$ brine and dried over anhydrous $\mathrm{Na}_{2} \mathrm{SO}_{4}$, filtered and concentrated under vacuum to give a residue. The residue was purified by flash silica gel chromatography (ISCO ${ }^{\circledR} ; 80.0 \mathrm{~g}$ SepaFlash ${ }^{\circledR}$ Silica Flash Column, Eluent of 0 4\% EtOAc/petroleum ether 
gradient) to give 5-bromo-1,2-dichloro-3-((4-methoxybenzyl)oxy)benzene (60.0 g, 89.8\% yield) as a white solid.

To a solution of 5-bromo-1,2-dichloro-3-((4-methoxybenzyl)oxy)benzene (59.0 g, 162 $\mathrm{mmol}, 1.00 \mathrm{eq})$ in THF $(600 \mathrm{~mL})$ was added i-PrMgCl$\cdot \mathrm{LiCl}(1.3 \mathrm{M}, 250 \mathrm{~mL}, 2.00 \mathrm{eq})$ at $0{ }^{\circ} \mathrm{C}$. The mixture was stirred at $25^{\circ} \mathrm{C}$ for $2 \mathrm{~h}$. Then DMF $(35.7 \mathrm{~g}, 488 \mathrm{mmol}, 37.6 \mathrm{~mL}, 3.00 \mathrm{eq})$ was added drop-wise and the resulting mixture was stirred at $25^{\circ} \mathrm{C}$ for $1 \mathrm{~h}$. The reaction mixture was quenched with $500 \mathrm{~mL}$ saturated aqueous $\mathrm{NH}_{4} \mathrm{Cl}$ and extracted with EtOAc $(400 \mathrm{~mL} \times 3)$. The combined organic phase was washed with $500 \mathrm{~mL}$ brine and dried over anhydrous $\mathrm{Na}_{2} \mathrm{SO}_{4}$, filtered and concentrated under vacuum to give a residue. The residue was triturated with 150 $\mathrm{mL}$ petroleum ether at $25{ }^{\circ} \mathrm{C}$ for $8 \mathrm{~h}$, and then filtered to collect S3-1 (48.0 g, 94.6\% yield) as a white solid.

\section{2-(3,4-Dichloro-5-((4-methoxybenzyl)oxy)phenyl)acetonitrile (S3-2): To a solution of S3-1}

(48.0 g, $154 \mathrm{mmol}, 1.00 \mathrm{eq})$ in THF $(500 \mathrm{~mL})$ was added $\mathrm{NaBH}_{4}(11.6 \mathrm{~g}, 307 \mathrm{mmol}, 2.00 \mathrm{eq})$ at $0{ }^{\circ} \mathrm{C}$ and the mixture was stirred at $15^{\circ} \mathrm{C}$ for $1 \mathrm{~h}$. The mixture was quenched with $400 \mathrm{~mL}$ water and extracted with EtOAc $(300 \mathrm{~mL} \times 3)$. The combined organic phase was washed with $500 \mathrm{~mL}$ brine and dried over anhydrous $\mathrm{Na}_{2} \mathrm{SO}_{4}$, filtered and concentrated under vacuum to give $(3,4-$ dichloro-5-((4-methoxybenzyl)oxy)phenyl)methanol (46.0 g, 95.2\% yield) as a light yellow solid.

To a solution of (3,4-dichloro-5-((4-methoxybenzyl)oxy)phenyl)methanol (46.0 g, 146 mmol, 1.00 eq) in $\mathrm{Et}_{3} \mathrm{~N}$ (44.5 g, $\left.440 \mathrm{mmol}, 61.3 \mathrm{~mL}, 3.00 \mathrm{eq}\right)$ and DCM (500 mL) was added $\mathrm{MsCl}(23.7 \mathrm{~g}, 207 \mathrm{mmol}, 16.0 \mathrm{~mL}, 1.41 \mathrm{eq})$ at $0{ }^{\circ} \mathrm{C}$. Then the mixture was stirred at $0{ }^{\circ} \mathrm{C}$ for 1 h. The reaction mixture was washed with brine $(400 \mathrm{~mL} \times 3)$ and dried over anhydrous $\mathrm{Na}_{2} \mathrm{SO}_{4}$, filtered and concentrated under vacuum to give the corresponding mesylate (37.0 g, 64.3\% yield) 
as yellow oil. To a solution of the mesylate $(37.0 \mathrm{~g}, 94.5 \mathrm{mmol}, 1.00 \mathrm{eq})$ in EtOH $(740 \mathrm{~mL})$ was added a solution of $\mathrm{NaCN}(8.59 \mathrm{~g}, 175 \mathrm{mmol}, 1.85 \mathrm{eq})$ in water $(185 \mathrm{~mL})$ at $25^{\circ} \mathrm{C}$. The mixture was stirred at $80^{\circ} \mathrm{C}$ for $8 \mathrm{~h}$. The reaction mixture was concentrated under vacuum to remove EtOH and extracted with EtOAc $(200 \mathrm{~mL} \times 3)$. The combined organic phase was washed with $300 \mathrm{~mL}$ brine and dried over anhydrous $\mathrm{Na}_{2} \mathrm{SO}_{4}$, filtered and concentrated under vacuum to give a residue. The residue was purified by column chromatography $\left(\mathrm{SiO}_{2}\right.$, petroleum ether/EtOAc $=$ 20/1 3/1, $\left.\mathrm{R}_{\mathrm{f}}=0.38\right)$ to give S3-2 (16.5 $\mathrm{g}, 54.1 \%$ yield) as a white solid.

\section{Methyl 2-(3,4-dichloro-5-(4,4,5,5-tetramethyl-1,3,2-dioxaborolan-2-yl)phenyl)acetate (S3-}

3a): To a solution of 2-(3,4-dichloro-5-((4-methoxybenzyl)oxy)phenyl)acetonitrile $16.0 \mathrm{~g}, 49.6$ mmol, $1.00 \mathrm{eq})$ in $\mathrm{MeOH}(192 \mathrm{~mL})$ was added $\mathrm{H}_{2} \mathrm{SO}_{4}(117 \mathrm{~g}, 1.20 \mathrm{~mol}, 64.0 \mathrm{~mL}, 24.1 \mathrm{eq})$ at 0 ${ }^{\circ} \mathrm{C}$. The mixture was stirred at $80{ }^{\circ} \mathrm{C}$ for $36 \mathrm{~h}$. The mixture was poured into $600 \mathrm{~mL}$ saturate $\mathrm{NaHCO}_{3}$ and extracted with EtOAc $(300 \mathrm{~mL} \times 3)$. The combined organic phase was washed with $500 \mathrm{~mL}$ brine and dried over anhydrous $\mathrm{Na}_{2} \mathrm{SO}_{4}$, filtered and concentrated under vacuum to give a residue. The residue was purified by flash silica gel chromatography (ISCOR; $18.0 \mathrm{~g}$ SepaFlash ${ }^{\circledR}$ Silica Flash Column, Eluent of $0 \sim 30 \%$ EtOAc/petroleum ether gradient, $\mathrm{R}_{\mathrm{f}}=0.23$ ) to give methyl 2-(3,4-dichloro-5-hydroxyphenyl)acetate $(9.30 \mathrm{~g}, 79.6 \%$ yield $)$ as a white solid.

To a solution of methyl 2-(3,4-dichloro-5-hydroxyphenyl)acetate (8.20 g, $34.8 \mathrm{mmol}$, $1.00 \mathrm{eq})$ in pyridine $(50 \mathrm{~mL})$ was added $\mathrm{Tf}_{2} \mathrm{O}(10.8 \mathrm{~g}, 38.3 \mathrm{mmol}, 6.33 \mathrm{~mL}, 1.10 \mathrm{eq})$ at $0{ }^{\circ} \mathrm{C}$. The mixture was stirred at $20^{\circ} \mathrm{C}$ for $1 \mathrm{~h}$. The reaction mixture was diluted with $150 \mathrm{~mL}$ EtOAc and washed with $1 \mathrm{~N} \mathrm{HCl}(100 \mathrm{~mL} \times 2)$. The organic phase was washed with brine $(100 \mathrm{~mL} \times 2)$ and dried over anhydrous $\mathrm{Na}_{2} \mathrm{SO}_{4}$, filtered and concentrated under vacuum to give the triflate (12.5 g, crude) as yellow oil. To a solution of the triflate $(12.5 \mathrm{~g}, 34.0 \mathrm{mmol}, 1.00 \mathrm{eq})$ in $1,4-$ dioxane $(130 \mathrm{~mL})$ were added bis(pinacolato)diboron (BPD, $8.65 \mathrm{~g}, 34.0 \mathrm{mmol}, 1.00 \mathrm{eq})$, 
$\mathrm{Pd}(\mathrm{dppf}) \mathrm{Cl}_{2}(2.50 \mathrm{~g}, 3.42 \mathrm{mmol}, 0.10 \mathrm{eq})$ and KOAc (10.0 g, $\left.102 \mathrm{mmol}, 3.00 \mathrm{eq}\right)$ under $\mathrm{N}_{2}$. The mixture was stirred at $100{ }^{\circ} \mathrm{C}$ for $2 \mathrm{~h}$. The mixture was filtered through a pad of celite and the filtrate was concentrated under vacuum to give a residue. The residue was purified by column $\left(\mathrm{SiO}_{2}\right.$, petroleum ether/EtOAc $\left.=20 / 1 \sim 4 / 1, \mathrm{R}_{\mathrm{f}}=0.54\right)$ to give $\mathbf{S 3 - 3 a}(15.0 \mathrm{~g}$, crude $)$ as yellow oil.

\section{Methyl 2-(3-(3-amino-5-chloropyrazin-2-yl)-4,5-dichlorophenyl)acetate (S3-4a): To a} solution of S3-3a (14.9 g, $43.1 \mathrm{mmol}, 1.50 \mathrm{eq})$ in 1,4-dioxane (160 mL) were added 3-bromo-6chloropyrazin-2-amine (6.00 g, $28.7 \mathrm{mmol}, 1.00 \mathrm{eq}), \mathrm{Pd}(\mathrm{dppf}) \mathrm{Cl}_{2}(2.11 \mathrm{~g}, 2.88 \mathrm{mmol}, 0.10 \mathrm{eq})$ and $\mathrm{K}_{3} \mathrm{PO}_{4}(13.0 \mathrm{~g}, 61.2 \mathrm{mmol}, 2.13 \mathrm{eq})$ under $\mathrm{N}_{2}$. The mixture was stirred at $110{ }^{\circ} \mathrm{C}$ for $2 \mathrm{~h}$. The reaction mixture was filtered through a pad of celite and the filtrate was concentrated under vacuum to give a residue. The residue was purified by column chromatography $\left(\mathrm{SiO}_{2}\right.$, petroleum ether/EtOAc $=15 / 1 \sim 1 / 1$, TLC: petroleum ether $/$ EtOAc $\left.=2 / 1, R_{f}=0.45\right)$ to give S3-4a $(9.00 \mathrm{~g}$, $90.2 \%$ yield) as a yellow solid.

\section{Tert-butyl (1-(6-amino-5-(2,3-dichloro-5-(2-hydroxyethyl)phenyl)pyrazin-2-yl)-4-}

methylpiperidin-4-yl)carbamate (Intermediate 3): To a solution of S3-4 (1.20 g, $3.46 \mathrm{mmol}$, $1.00 \mathrm{eq})$ in NMP (10 mL) were added tert-butyl (4-methylpiperidin-4-yl)carbamate (840 mg, $3.92 \mathrm{mmol}, 1.13 \mathrm{eq})$ and DIPEA (2.24 g, $17.3 \mathrm{mmol}, 3.02 \mathrm{~mL}, 5.00 \mathrm{eq})$. The suspension was degassed and purged with $\mathrm{N}_{2} 3$ times and stirred at $150{ }^{\circ} \mathrm{C}$ for $2 \mathrm{~h}$ under microwave. The reaction mixture was diluted with $100 \mathrm{~mL}$ water and extracted with EtOAc $(60 \mathrm{~mL} \times 3)$. The combined organic phase was washed with brine $(100 \mathrm{~mL} \times 3)$ and dried over anhydrous $\mathrm{Na}_{2} \mathrm{SO}_{4}$, filtered and concentrated under vacuum to give a residue. The residue was purified by flash silica gel chromatography (ISCO®); 12.0 g SepaFlash ${ }^{\circledR}$ Silica Flash Column, Eluent of 0 50\% EtOAc/petroleum ether gradient, $\left.\mathrm{R}_{\mathrm{f}}=0.38\right)$ to give methyl 2-(3-(3-amino-5-(4-((tert- 
butoxycarbonyl)amino)-4-methylpiperidin-1-yl)pyrazin-2-yl)-4,5-dichlorophenyl)acetate (2.60 g, crude) as a yellow solid.

To a solution of methyl 2-(3-(3-amino-5-(4-((tert-butoxycarbonyl)amino)-4methylpiperidin-1-yl)pyrazin-2-yl)-4,5-dichlorophenyl)acetate (2.50 g, $4.77 \mathrm{mmol}, 1.00 \mathrm{eq})$ in THF $(30 \mathrm{~mL})$ was added $\mathrm{LiAlH}_{4}(181 \mathrm{mg}, 4.77 \mathrm{mmol}, 1.00 \mathrm{eq})$ at $0{ }^{\circ} \mathrm{C}$ and the mixture was stirred at $0{ }^{\circ} \mathrm{C}$ for $0.5 \mathrm{~h}$. The mixture was quenched with $0.15 \mathrm{~mL}$ water, $0.15 \mathrm{~mL} 15 \% \mathrm{NaOH}$ and $0.3 \mathrm{~mL}$ water at $0{ }^{\circ} \mathrm{C}$. Next, $2.00 \mathrm{~g} \mathrm{MgSO}_{4}$ was added. The mixture was stirred at $25^{\circ} \mathrm{C}$ for $30 \mathrm{~min}$. Then filtered through a pad of celite and the filtrate was concentrated under vacuum to give a residue. The residue was purified by reversed-phase HPLC ( $0.1 \%$ formic acid condition) to give Intermediate 3 (650 mg, 27.4\% yield) as a yellow foam.

2,3-Dichloro-4-(4,4,5,5-tetramethyl-1,3,2-dioxaborolan-2-yl)phenol (S3-3b): To a solution of 2,3-dichlorophenol (40.0 g, $245 \mathrm{mmol}, 1.00 \mathrm{eq})$ in DCM (200 mL) was added $\mathrm{Br}_{2}(43.1 \mathrm{~g}, 270$ mmol, $13.9 \mathrm{~mL}, 1.10 \mathrm{eq}$ ) over $30 \mathrm{mins}$ at $0{ }^{\circ} \mathrm{C}$. The mixture was warmed to $15^{\circ} \mathrm{C}$ for $16 \mathrm{~h}$. The mixture was washed with $10 \%$ aqueous $\mathrm{Na}_{2} \mathrm{SO}_{3}(240 \mathrm{~mL})$ and then washed with brine $(120 \mathrm{~mL})$. The combined water phase was washed with DCM $(150 \mathrm{~mL})$. The combined organic phase was dried over anhydrous $\mathrm{Na}_{2} \mathrm{SO}_{4}$, filtered and concentrated under reduced pressure to give a residue. The residue was purified by column chromatography $\left(\mathrm{SiO}_{2}\right.$, petroleum ether: EtOAc $=100: 1$ to 0:1) to five 4-bromo-2,3-dichlorophenol (25.7 g, $106 \mathrm{mmol}, 43.3 \%$ yield, 100\% purity) as an offwhite solid.

To a solution of 4-bromo-2,3-dichlorophenol (4.00 g, $16.5 \mathrm{mmol}, 1.00 \mathrm{eq})$, BPD (5.46 g, $21.5 \mathrm{mmol}, 2.53 \mathrm{~mL}, 1.30 \mathrm{eq})$ and $\mathrm{AcOK}(4.87 \mathrm{~g}, 49.6 \mathrm{mmol}, 3.00 \mathrm{eq})$ in 1,4-dioxane (40.0 mL), was added $\mathrm{Pd}(\mathrm{dppf}) \mathrm{Cl}_{2} \bullet \mathrm{DCM}(1.08 \mathrm{~g}, 1.32 \mathrm{mmol}, 0.08 \mathrm{eq})$ under $\mathrm{N}_{2}$. The mixture was stirred at 
$90{ }^{\circ} \mathrm{C}$ for $15 \mathrm{~h}$. The reaction mixture was filtered, and the residue was washed with EtOAc (100 $\mathrm{mL} \times 4)$ and the filtrate was concentrated. The residue was purified by column chromatography $\left(\mathrm{SiO}_{2}\right.$, petroleum ether : EtOAc $=100: 1$ to 10: 1 , TLC: petroleum ether $:$ EtOAc $=5: 1, \mathrm{R}_{\mathrm{f}}=$ 0.49). to give S3-3b (2.50 g, $8.10 \mathrm{mmol}, 49.0 \%$ yield, $93.6 \%$ purity) as a white solid.

4-(3-Amino-5-chloropyrazin-2-yl)-2,3-dichlorophenol (S3-4b): The following reactions were done two times. To a solution of 3-bromo-6-chloropyrazin-2-amine (731 mg, $3.51 \mathrm{mmol}, 1.00$ eq) and S3-3b (1.30 g, $4.21 \mathrm{mmol}, 1.20 \mathrm{eq})$ in water $(2.00 \mathrm{~mL})$ and 1,4-dioxane $(8.00 \mathrm{~mL})$ was added $\mathrm{K}_{3} \mathrm{PO}_{4}(2.61 \mathrm{~g}, 12.3 \mathrm{mmol}, 3.50 \mathrm{eq})$ and $\mathrm{Pd}(\mathrm{dppf}) \mathrm{Cl}_{2}(128 \mathrm{mg}, 175 \mathrm{umol}, 0.05 \mathrm{eq})$. The reaction mixture was stirred at $110^{\circ} \mathrm{C}$ for $1.5 \mathrm{~h}$. The reaction mixture was filtered and concentrated under reduced pressure to give a residue. The residue was diluted with water (10.0 $\mathrm{mL})$ and extracted with EtAcO $(10.0 \mathrm{~mL} \times 2)$. The combined organic layers were washed with brine $(20.0 \mathrm{~mL})$, dried over anhydrous $\mathrm{Na}_{2} \mathrm{SO}_{4}$, filtered and concentrated under reduced pressure to give a residue. The two batches were combined to purify by prep-HPLC (neutral condition) to give S3-4b (1.03 g, $3.51 \mathrm{mmol}, 78.5 \%$ yield, 99.0\% purity) as a yellow solid.

Tert-butyl (1-(6-amino-5-(2,3-dichloro-4-hydroxyphenyl)pyrazin-2-yl)-4-methylpiperidin-4yl)carbamate (Intermediate 4): S3-4b (1.03 g, $3.51 \mathrm{mmol}, 1.00 \mathrm{eq})$, tert-butyl (4methylpiperidin-4-yl)carbamate (1.13 g, $5.26 \mathrm{mmol}, 1.50 \mathrm{eq})$ and DIPEA (2.27 g, $17.6 \mathrm{mmol}$, $3.06 \mathrm{~mL}, 5.00 \mathrm{eq})$ were taken up into a microwave tube in NMP $(10.0 \mathrm{~mL})$. The sealed tube was heated at $150{ }^{\circ} \mathrm{C}$ for $2 \mathrm{~h}$ under microwave. The mixture was partitioned between water $(20.0$ $\mathrm{mL})$ and EtOAc $(20.0 \mathrm{~mL})$. The water phase was separated, washed with EtOAc $(20.0 \mathrm{~mL} \times 4)$. The combined organic phase was washed with brine $(10.0 \mathrm{~mL})$, dried over anhydrous $\mathrm{Na}_{2} \mathrm{SO}_{4}$, filtered and concentrated under reduced pressure to give a residue. The residue was purified by 
prep-HPLC (neutral condition) to give Intermediate 4 (700 mg, 1.39 mmol, 39.7\% yield, 93.3\% purity as a brown solid.

\section{Scheme 4}<smiles>COc1cc(Cl)c(Cl)c(Br)c1</smiles>

S4-1<smiles>CC(C)(C)NC1(C)CCN(c2cnc(-c3cc(O)cc(Cl)c3Cl)c(N)n2)CC1</smiles>

S4-2

Intermediate $\mathbf{5}$

(2,3-Dichloro-5-methoxyphenyl)boronic acid (S4-1): To a solution of 1-bromo-2,3-dichloro-5methoxybenzene $(5.00 \mathrm{~g}, 19.2 \mathrm{mmol}, 1.00 \mathrm{eq})$ in THF $(100 \mathrm{~mL})$ was added dropwise i$\operatorname{PrMgCl} \cdot \mathrm{LiCl}(1.30 \mathrm{M}, 23.9 \mathrm{~mL}, 1.62 \mathrm{eq})$ at $0{ }^{\circ} \mathrm{C}$ under $\mathrm{N}_{2}$. The mixture was stirred at $0{ }^{\circ} \mathrm{C}$ for 1 h. Then trimethyl borate $(9.95 \mathrm{~g}, 95.8 \mathrm{mmol}, 10.8 \mathrm{~mL}, 5.00 \mathrm{eq})$ was added at $0{ }^{\circ} \mathrm{C}$ and the mixture stirred for $1 \mathrm{~h}$. Next, $\mathrm{HCl}(1.00 \mathrm{M}, 51.5 \mathrm{~mL}, 2.69 \mathrm{eq})$ was added and stirred at $0{ }^{\circ} \mathrm{C}$ for 1 h. The organic phase was separated, filtered and concentrated under reduced pressure to give a residue S4-1 (4.90 g, $17.9 \mathrm{mmol}, 93.6 \%$ yield, $80.8 \%$ purity) as a white solid.

3-(3-Amino-5-chloropyrazin-2-yl)-4,5-dichlorophenol (S4-2): A mixture of S4-1 (2.00 g, 7.32 mmol, 1.20 eq), 3-bromo-6-chloropyrazin-2-amine (1.27 g, $6.10 \mathrm{mmol}, 1.00 \mathrm{eq}), \mathrm{Pd}\left(\mathrm{PPh}_{3}\right)_{4}(564$ mg, 488 umol, 0.080 eq) and $\mathrm{Na}_{2} \mathrm{CO}_{3}(1.29 \mathrm{~g}, 12.20 \mathrm{mmol}, 2.00 \mathrm{eq})$ in toluene (10.0 mL) was added water $(2.00 \mathrm{~mL})$ and $\mathrm{EtOH}(4.00 \mathrm{~mL})$. Then the mixture was degassed and purged with 
$\mathrm{N}_{2}$ three times. The mixture was stirred at $100{ }^{\circ} \mathrm{C}$ for $16 \mathrm{~h}$ under a $\mathrm{N}_{2}$ atmosphere. The reaction mixture was partitioned between ethyl aceate $(100 \mathrm{~mL})$ and water $(80.0 \mathrm{~mL})$. The water phase was separated, washed with ethyl aceate $(100 \mathrm{~mL} \times 3)$. The combined organic phase was washed with brine $(60.0 \mathrm{~mL} \times 2)$, dried over anhydrous $\mathrm{Na}_{2} \mathrm{SO}_{4}$, filtered and concentrated under reduced pressure to give a residue. The residue was purified by column chromatography $\left(\mathrm{SiO}_{2}\right.$, petroleum ether : EtOAc $=20: 1$ to 3: 1, TLC: petroleum ether $:$ EtOAc $=3: 1, \mathrm{R}_{\mathrm{f}}=0.62$ ) to give 6-chloro-3-(2,3-dichloro-5-methoxyphenyl)pyrazin-2-amine (1.70 g, $5.24 \mathrm{mmol}, 86.0 \%$ yield, 93.9\% purity) was obtained as a yellow solid.

To a solution of 6-chloro-3-(2,3-dichloro-5-methoxyphenyl)pyrazin-2-amine (1.70 g, $5.24 \mathrm{mmol}, 1.00 \mathrm{eq})$ in DCM $(85.0 \mathrm{~mL})$ was added dropwise $\mathrm{BBr}_{3}(1 \mathrm{M}, 10.5 \mathrm{~mL}, 2.00 \mathrm{eq})$ at $78{ }^{\circ} \mathrm{C}$ over $1 \mathrm{~h}$. After the addition, the resulting mixture was stirred at $40{ }^{\circ} \mathrm{C}$ for $21 \mathrm{~h}$. The mixture was poured into ice water $(150 \mathrm{~mL})$ and washed with DCM $(100 \mathrm{~mL} \times 3)$. The combined organic phase was washed with brine $(100 \mathrm{~mL})$, dried over anhydrous $\mathrm{Na}_{2} \mathrm{SO}_{4}$, filtered and concentrated under reduced pressure to give a residue. The residue was purified by prepHPLC (TFA condition) to give $\mathbf{S 4 - 2}$ (370 $\mathrm{mg}, 1.19 \mathrm{mmol}, 22.7 \%$ yield, $93.5 \%$ purity) as a yellow solid.

\section{Tert-butyl (1-(6-amino-5-(2,3-dichloro-5-hydroxyphenyl)pyrazin-2-yl)-4-methylpiperidin-4-}

yl)carbamate (Intermediate 5): S4-2 (520 mg, 1.79 mmol, 1.00 eq), tert-butyl (4methylpiperidin-4-yl)carbamate (575 mg, $2.68 \mathrm{mmol}, 1.50 \mathrm{eq})$ and DIPEA (1.16 g, $8.95 \mathrm{mmol}$, $1.56 \mathrm{~mL}, 5.00 \mathrm{eq})$ were taken up into a microwave tube in NMP (5.00 mL). The sealed tube was heated at $150^{\circ} \mathrm{C}$ for $2 \mathrm{~h}$ under microwave. The combined mixture was partitioned between water $(20.0 \mathrm{~mL})$ and EtOAc $(20.0 \mathrm{~mL})$. The water phase was separated, washed with EtOAc $(20.0 \mathrm{~mL}$ $\times 4)$. The combined organic phase was washed with brine $(10.0 \mathrm{~mL} \times 3)$, dried over anhydrous 
$\mathrm{Na}_{2} \mathrm{SO}_{4}$, filtered and concentrated under reduced pressure to give a residue. The residue was purified by column chromatography $\left(\mathrm{SiO}_{2}\right.$, petroleum ether : EtOAc $=10: 1$ to 1: 1, TLC: petroleum ether : $\left.\mathrm{EtOAc}=1: 1, \mathrm{R}_{\mathrm{f}}=0.40\right)$ to give Intermediate $5(450 \mathrm{mg}, 888$ umol, 49.6\% yield, $92.4 \%$ purity) as a yellow oil.

\section{Scheme 5}

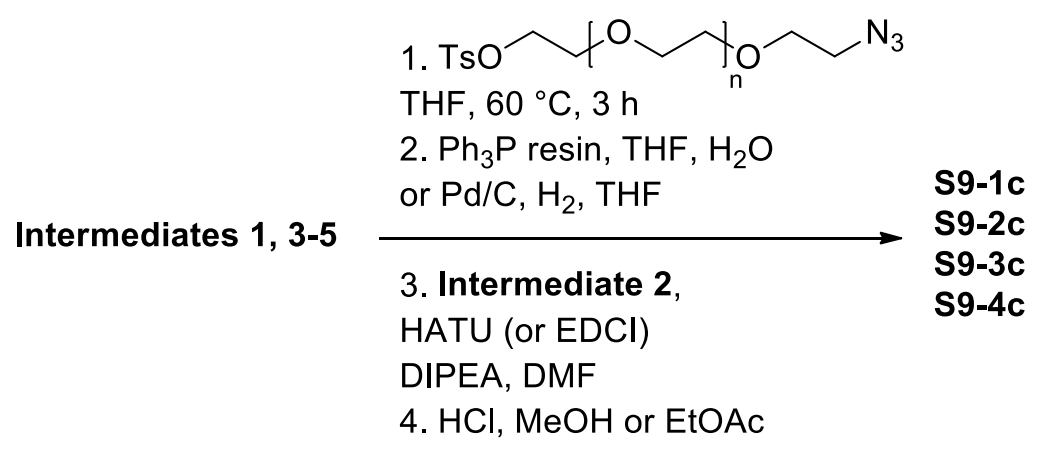

Synthesis of S9-1c: To a solution of Intermediate 1 (100 mg, $184 \mathrm{umol}, 1.00 \mathrm{eq})$ in THF (1.5 $\mathrm{mL}$ ) was added $\mathrm{NaH}(15.0 \mathrm{mg}, 375 \mathrm{umol}, 60 \%$ purity, $2.03 \mathrm{eq})$ at $0{ }^{\circ} \mathrm{C}$, followed by addition $14-$ azido-3,6,9,12-tetraoxatetradecyl 4-methylbenzenesulfonate (100 mg, 239 umol, 1.30 eq). The mixture was stirred at $60{ }^{\circ} \mathrm{C}$ for $3 \mathrm{~h}$. The mixture was quenched with $(2 \mathrm{~mL})$ water and extracted with EtOAc $(2 \mathrm{~mL} \times 3)$. The combined organic phase was concentrated under vacuum to give a residue. The residue was purified by prep. TLC (dichloromethane/methanol = 10/1, TLC: dichloromethane/methanol $\left.=10 / 1, \mathrm{R}_{\mathrm{f}}=0.55\right)$ to give tert-butyl (1-(6-amino-5-(4-(17-azido3,6,9,12,15-pentaoxaheptadecyl)-2,3-dichlorophenyl)pyrazin-2-yl)-4-methylpiperidin-4yl)carbamate (50.0 mg, 34.0\% yield, 93.4\% purity) as yellow oil.

To a solution of tert-butyl (1-(6-amino-5-(4-(17-azido-3,6,9,12,15-pentaoxaheptadecyl)2,3-dichlorophenyl)pyrazin-2-yl)-4-methylpiperidin-4-yl)carbamate (40.0 mg, 50.3 umol, 1.00 eq) in THF (1 mL) and water $(0.3 \mathrm{~mL})$ was added $\mathrm{PPh}_{3}(13.2 \mathrm{mg}, 50.3$ umol, $1.00 \mathrm{eq})$. The 
mixture was stirred at $60{ }^{\circ} \mathrm{C}$ for $3 \mathrm{~h}$. The mixture was diluted with $5 \mathrm{~mL}$ EtOAc and washed with $5 \mathrm{~mL}$ brine. The organic phase was concentrated under vacuum to give a residue. The residue was purified by prep. TLC (dichloromethane/methanol $=10 / 1$, TLC: dichloromethane/methanol $\left.=10 / 1, \mathrm{R}_{\mathrm{f}}=0.11\right)$ to give tert-butyl (1-(6-amino-5-(4-(17-amino3,6,9,12,15-pentaoxaheptadecyl)-2,3-dichlorophenyl)pyrazin-2-yl)-4-methylpiperidin-4yl)carbamate $(25.0 \mathrm{mg}, 69.3 \%$ yield) as yellow oil.

A mixture of tert-butyl (1-(6-amino-5-(4-(17-amino-3,6,9,12,15-pentaoxaheptadecyl)2,3-dichlorophenyl)pyrazin-2-yl)-4-methylpiperidin-4-yl)carbamate (25.0 mg, 34.9 umol, 1.00 eq), Intermediate 2 (19.3 mg, 52.4 umol, 1.50 eq), HATU (19.9 mg, 52.4 umol, 1.50 eq) and DIPEA (13.5 mg, 104 umol, $18.2 \mathrm{uL}, 3.00 \mathrm{eq})$ in DMF $(1 \mathrm{~mL})$ was stirred at $25{ }^{\circ} \mathrm{C}$ for $0.5 \mathrm{~h}$. The mixture was acidified to $\mathrm{pH} \sim 6$ with $1 \mathrm{M} \mathrm{HCl}$ and purified by prep. HPLC (column: Phenomenex Synergi C18 150*25*10um;mobile phase: [water $(0.05 \% \mathrm{HCl})$-acetonitrile];B\%: 48\%-68\%, $10 \mathrm{~min})$ and lyophilized to give tert-butyl (1-(6-amino-5-(2,3-dichloro-4-(1-((2-(2,6dioxopiperidin-3-yl)-1,3-dioxoisoindolin-4-yl)oxy)-2-oxo-6,9,12,15,18-pentaoxa-3-azaicosan20-yl)phenyl)pyrazin-2-yl)-4-methylpiperidin-4-yl)carbamate (15.0 mg, 41.6\% yield) as a yellow solid.

A mixture of tert-butyl (1-(6-amino-5-(2,3-dichloro-4-(1-((2-(2,6-dioxopiperidin-3-yl)1,3-dioxoisoindolin-4-yl)oxy)-2-oxo-6,9,12,15,18-pentaoxa-3-azaicosan-20-yl)phenyl)pyrazin-2yl)-4-methylpiperidin-4-yl)carbamate (15.0 mg, 14.5 umol, 1.00 eq) in HCl-1,4-dioxane (4 M, $0.2 \mathrm{~mL}, 54.9 \mathrm{eq})$ and EtOAc $(0.2 \mathrm{~mL})$ was stirred at $20^{\circ} \mathrm{C}$ for $0.5 \mathrm{~h}$. The mixture was concentrated under vacuum to give a residue. The residue was purified by prep. HPLC (column: Phenomenex Synergi C18 150*25*10um; mobile phase: [water $(0.05 \% \mathrm{HCl})$ - acetonitrile]; B\%: 
$22 \%-42 \%, 9.5 \mathrm{~min})$ and lyophilized to give S9-1c $(2.89 \mathrm{mg}, 20.3 \%$ yield, $95.3 \%$ purity) as a yellow solid.

Synthesis of S9-2c: The following reactions were done three times. To a solution of Intermediate 3 (50.0 mg, 100 umol, 1.00 eq) in THF (1 mL) was added NaH (8.06 mg, 201 umol, $60 \%$ purity, $2.00 \mathrm{eq}$ ) at $0{ }^{\circ} \mathrm{C}$ and the mixture was stirred at $40{ }^{\circ} \mathrm{C}$ for $1 \mathrm{~h} .14$-Azido3,6,9,12-tetraoxatetradecyl 4-methylbenzenesulfonate (45.1 mg, $120 \mathrm{umol}, 1.20 \mathrm{eq}$ ) was added to the reaction mixture at $0{ }^{\circ} \mathrm{C}$. The resulting mixture was stirred at $55^{\circ} \mathrm{C}$ for $1 \mathrm{~h}$. The mixture was quenched with $10 \mathrm{~mL}$ sat. $\mathrm{NH}_{4} \mathrm{Cl}$. The three reaction batches were combined and the resulting mixture was extracted with EtOAc $(10 \mathrm{~mL} \times 3)$. The combined organic phase was washed with $30 \mathrm{~mL}$ brine and dried over $\mathrm{Na}_{2} \mathrm{SO}_{4}$, filtered and concentrated under vacuum to give a residue. The residue was purified by reversed-phase HPLC (0.1\% FA condition) to give tert-butyl (1-(6amino-5-(5-(17-azido-3,6,9,12,15-pentaoxaheptadecyl)-2,3-dichlorophenyl)pyrazin-2-yl)-4methylpiperidin-4-yl)carbamate (60.0 mg, 75.0\% purity) as a yellow oil.

A mixture of tert-butyl (1-(6-amino-5-(5-(17-azido-3,6,9,12,15-pentaoxaheptadecyl)-2,3dichlorophenyl)pyrazin-2-yl)-4-methylpiperidin-4-yl)carbamate (58.0 mg, 78.2 umol, $1.00 \mathrm{eq})$ and $\mathrm{PPh}_{3}$ resin $(61.2 \mathrm{mg}, 234 \mathrm{umol}, 3.00 \mathrm{eq})$ in THF $(1 \mathrm{~mL})$ and water $(0.3 \mathrm{~mL})$ was stirred at 50 ${ }^{\circ} \mathrm{C}$ for $4 \mathrm{~h}$. The reaction mixture was filtered and the filtrate was concentrated under vacuum to give tert-butyl (1-(6-amino-5-(5-(17-amino-3,6,9,12,15-pentaoxaheptadecyl)-2,3dichlorophenyl)pyrazin-2-yl)-4-methylpiperidin-4-yl)carbamate (60.0 mg, crude) as a yellow oil.

A mixture of tert-butyl (1-(6-amino-5-(5-(17-amino-3,6,9,12,15-pentaoxaheptadecyl)2,3-dichlorophenyl)pyrazin-2-yl)-4-methylpiperidin-4-yl)carbamate (60.0 mg, 83.8 umol, 1.00 eq), Intermediate 2 (42.0 mg, 126 umol, 1.51 eq), EDCI (28.0 mg, 146 umol, 1.74 eq), HOBt 
(21.0 mg, 155umol, $1.85 \mathrm{eq})$ and DIPEA (43.0 mg, $332 \mathrm{umol}, 3.97 \mathrm{eq})$ in DMF (1 mL) was stirred at $25^{\circ} \mathrm{C}$ for $1 \mathrm{~h}$. The reaction mixture was neutralized with $1 \mathrm{M} \mathrm{HCl}$ (in DMF) and purified by prep. HPLC (column: Phenomenex Synergi C18 150*25*10um; mobile phase: [water $(0.05 \% \mathrm{HCl})$ - acetonitrile]; $\mathrm{B} \%: 43 \%-63 \%, 8 \mathrm{~min})$ to give tert-butyl (1-(6-amino-5-(2,3dichloro-5-(1-((2-(2,6-dioxopiperidin-3-yl)-1,3-dioxoisoindolin-4-yl)oxy)-2-oxo-6,9,12,15,18pentaoxa-3-azaicosan-20-yl)phenyl)pyrazin-2-yl)-4-methylpiperidin-4-yl)carbamate (45.0 mg, $52.1 \%$ yield) as a yellow solid.

A mixture of tert-butyl (1-(6-amino-5-(2,3-dichloro-5-(1-((2-(2,6-dioxopiperidin-3-yl)1,3-dioxoisoindolin-4-yl)oxy)-2-oxo-6,9,12,15,18-pentaoxa-3-azaicosan-20-yl)phenyl)pyrazin-2yl)-4-methylpiperidin-4-yl)carbamate (45.0 mg, $43.6 \mathrm{umol}, 1.00 \mathrm{eq})$ in $\mathrm{MeOH}(0.5 \mathrm{~mL})$ and HCl-1,4-dioxane (4 M, $0.5 \mathrm{~mL}, 45.7 \mathrm{eq})$ was stirred at $25^{\circ} \mathrm{C}$ for $0.5 \mathrm{~h}$. The mixture was concentrated under vacuum to give a residue. The residue was purified by prep. HPLC (column: Phenomenex Synergi C18 150*25*10um; mobile phase: [water $(0.05 \% \mathrm{HCl})$ - acetonitrile]; B\%: 19\%-39\%, $6.5 \mathrm{~min})$ to give S9-2c (32.08 $\mathrm{mg}, 77.2 \%$ yield, $97.8 \%$ purity) as a yellow solid.

Synthesis of S9-3c: To a solution of compound Intermediate 4 (100 mg, 199 umol, 1.00 eq) and 17-azido-3,6,9,12,15-pentaoxaheptadecyl 4-methylbenzenesulfonate (123 mg, 239 umol, 1.20 eq) in DMF (0.500 mL) was added $\mathrm{K}_{2} \mathrm{CO}_{3}(55.1 \mathrm{mg}, 398 \mathrm{umol}, 2.00 \mathrm{eq})$. The mixture was stirred at $60{ }^{\circ} \mathrm{C}$ for $3 \mathrm{~h}$. The reaction mixture was partitioned between water $(2.00 \mathrm{~mL})$ and EtOAc $(2.00 \mathrm{~mL})$. The water phase was separated, washed with EtOAc $(2.00 \mathrm{~mL} \times 2)$. The combined organic phase was washed with brine $(2.00 \mathrm{~mL} \times 2)$, dried over anhydrous $\mathrm{Na}_{2} \mathrm{SO}_{4}$, filtered and concentrated under reduced pressure to give a residue. The residue was purified by prep-HPLC (neutral condition: column: Waters Xbridge $150 * 25 \mathrm{~mm} * 5 \mathrm{um}$; mobile phase: [water (10 mM $\left.\mathrm{NH}_{4} \mathrm{HCO}_{3}\right)$ - acetonitrile]; $\left.\mathrm{B} \%: 40 \%-70 \%, 10 \mathrm{~min}\right)$ to give tert-butyl (1-(6-amino-5-(4-((17- 
azido-3,6,9,12,15-pentaoxaheptadecyl)oxy)-2,3-dichlorophenyl)pyrazin-2-yl)-4-methylpiperidin4-yl)carbamate (66.0 mg, $87.1 \mathrm{umol}, 43.7 \%$ yield) as a yellow oil.

To a solution of tert-butyl (1-(6-amino-5-(4-((17-azido-3,6,9,12,15pentaoxaheptadecyl)oxy)-2,3-dichlorophenyl)pyrazin-2-yl)-4-methylpiperidin-4-yl)carbamate (66.0 mg, $87.1 \mathrm{umol}, 1.00 \mathrm{eq})$ in THF $(1.00 \mathrm{~mL})$ was added $10 \% \mathrm{Pd} / \mathrm{C}(7.00 \mathrm{mg}, 87.1 \mathrm{umol}, 1.00$ eq) under $\mathrm{N}_{2}$. The suspension was degassed under vacuum and purged with $\mathrm{H}_{2}$ several times. The mixture was stirred under $\mathrm{H}_{2}(15 \mathrm{psi})$ at $15^{\circ} \mathrm{C}$ for $2 \mathrm{~h}$. The mixture was filtered and the filtrate was concentrated under reduced pressure to afford tert-butyl (1-(6-amino-5-(4-((17amino-3,6,9,12,15-pentaoxaheptadecyl)oxy)-2,3-dichlorophenyl)pyrazin-2-yl)-4methylpiperidin-4-yl)carbamate (63.0 mg, 86.1 umol, $98.9 \%$ yield) as a brown oil, which was used without further purification.

To a solution of tert-butyl (1-(6-amino-5-(4-((17-amino-3,6,9,12,15pentaoxaheptadecyl)oxy)-2,3-dichlorophenyl)pyrazin-2-yl)-4-methylpiperidin-4-yl)carbamate (63.0 mg, $86.1 \mathrm{umol}, 1.00 \mathrm{eq})$ and Intermediate 2 (49.3 mg, $129 \mathrm{umol}, 1.50 \mathrm{eq}, \mathrm{HCl})$ in DMF (1.00 mL) was added HATU (39.3 mg, 103 umol, 1.20 eq), and DIPEA (50.1 mg, 387 umol, $67.5 \mathrm{uL}, 4.50 \mathrm{eq})$. Then the mixture was stirred at $15^{\circ} \mathrm{C}$ for $13 \mathrm{~h}$. The residue was purified by prep-HPLC (neutral condition: column: Waters Xbridge $150 * 25 \mathrm{~mm} * 5 \mathrm{um}$; mobile phase: [water (10 $\left.\mathrm{mM} \mathrm{NH}_{4} \mathrm{HCO}_{3}\right)$ - acetonitrile]; $\mathrm{B} \%$ : 32\%-62\%, $\left.10 \mathrm{~min}\right)$ to give tert-butyl (1-(6-amino-5-(2,3dichloro-4-((1-((2-(2,6-dioxopiperidin-3-yl)-1,3-dioxoisoindolin-4-yl)oxy)-2-oxo-6,9,12,15,18pentaoxa-3-azaicosan-20-yl)oxy)phenyl)pyrazin-2-yl)-4-methylpiperidin-4-yl)carbamate (77.0 mg, 73.6 umol, $85.5 \%$ yield) as a yellow solid. 
To a solution of compound tert-butyl (1-(6-amino-5-(2,3-dichloro-4-((1-((2--(2,6dioxopiperidin-3-yl)-1,3-dioxoisoindolin-4-yl)oxy)-2-oxo-6,9,12,15,18-pentaoxa-3-azaicosan20-yl)oxy)phenyl)pyrazin-2-yl)-4-methylpiperidin-4-yl)carbamate (77.0 mg, $73.6 \mathrm{umol}, 1.00 \mathrm{eq})$ in EtOAc $(0.700 \mathrm{~mL})$ was added $\mathrm{HCl} / \mathrm{EtOAc}(4 \mathrm{M}, 184 \mathrm{uL}, 10.0 \mathrm{eq})$, then the mixture was stirred at $15^{\circ} \mathrm{C}$ for $2 \mathrm{~h}$. The mixture was concentrated under reduced pressure to give a residue. The residue was purified by prep-HPLC ( $\mathrm{HCl}$ condition: column: Phenomenex Synergi C18 150*30mm*4um; mobile phase: [water $(0.05 \% \mathrm{HCl})$ - acetonitrile]; $\mathrm{B} \%$ : 6\%-36\%, $10 \mathrm{~min})$ to give S9-3c (29.5 mg, 29.5 umol, 40.1\% yield, 98.2\% purity, $\mathrm{HCl}$ ) as a yellow solid.

Synthesis of S9-4c: To a solution of Intermediate 5 (100 mg, 197 umol, 1.00 eq) and 17-azido3,6,9,12,15-pentaoxaheptadecyl 4-methylbenzenesulfonate (122 mg, 237 umol, 1.20 eq) in DMF (1.00 mL) was added $\mathrm{K}_{2} \mathrm{CO}_{3}(54.5 \mathrm{mg}, 395 \mathrm{umol}, 2.00 \mathrm{eq})$. The mixture was stirred at $60{ }^{\circ} \mathrm{C}$ for $3 \mathrm{~h}$. The reaction mixture was partitioned between water $(2.00 \mathrm{~mL})$ and EtOAc $(2.00 \mathrm{~mL})$. The water phase was separated, washed with ethyl aceate $(2.00 \mathrm{~mL} \times 2)$. The combined organic phase was washed with brine $(2.00 \mathrm{~mL} \times 2)$, dried over anhydrous $\mathrm{Na}_{2} \mathrm{SO}_{4}$, filtered and concentrated under reduced pressure to give a residue. The residue was purified by prep-HPLC (neutral condition: column: Waters Xbridge $150 * 25 \mathrm{~mm} *$ um; mobile phase: [water $\left(10 \mathrm{mM} \mathrm{NH}_{4} \mathrm{HCO}_{3}\right)$ acetonitrile]; B\%: 44\%-74\%, $10 \mathrm{~min})$. The product tert-butyl (1-(6-amino-5-(5-((17-azido3,6,9,12,15-pentaoxaheptadecyl)oxy)-2,3-dichlorophenyl)pyrazin-2-yl)-4-methylpiperidin-4yl)carbamate (79.0 mg, 104 umol, 52.9\% yield) was obtained as a yellow oil.

To a solution of tert-butyl (1-(6-amino-5-(5-((17-azido-3,6,9,12,15pentaoxaheptadecyl)oxy)-2,3-dichlorophenyl)pyrazin-2-yl)-4-methylpiperidin-4-yl)carbamate (79.0 mg, 104 umol, $1.00 \mathrm{eq})$ in THF (1.00 mL) was added 10\% Pd/C (8.00 mg, $10.4 \mathrm{umol}$, 0.100 eq) under $\mathrm{N}_{2}$. The suspension was degassed under vacuum and purged with $\mathrm{H}_{2}$ several 
times. The mixture was stirred under $\mathrm{H}_{2}(15 \mathrm{psi})$ at $15^{\circ} \mathrm{C}$ for $3 \mathrm{~h}$. The reaction mixture was filtered and concentrated under reduced pressure to give the product tert-butyl (1-(6-amino-5-(5((17-amino-3,6,9,12,15-pentaoxaheptadecyl)oxy)-2,3-dichlorophenyl)pyrazin-2-yl)-4methylpiperidin-4-yl)carbamate (80.0 mg, 93.9 umol, 90.1\% yield, 85.9\% purity) as a yellow oil.

To a solution of tert-butyl (1-(6-amino-5-(5-((17-amino-3,6,9,12,15pentaoxaheptadecyl)oxy)-2,3-dichlorophenyl)pyrazin-2-yl)-4-methylpiperidin-4-yl)carbamate (80.0 mg, 93.9 umol, $1.00 \mathrm{eq})$ and Intermediate 2 (53.8 mg, $141 \mathrm{umol}, 1.50 \mathrm{eq}, \mathrm{HCl})$ in DMF (1.00 mL) was added HATU (42.9 mg, 113 umol, 1.20 eq) and DIPEA (54.6 mg, 423 umol, 73.6 $\mathrm{uL}, 4.50 \mathrm{eq})$. The mixture was stirred at $15^{\circ} \mathrm{C}$ for $16 \mathrm{~h}$. The residue was purified by prep-HPLC (neutral condition: column: Phenomenex luna C18 150*25mm*10um; mobile phase: [water (10 $\mathrm{mM} \mathrm{NH}_{4} \mathrm{HCO}_{3}$ )- acetonitrile]; $\left.\mathrm{B} \%: 32 \%-62 \%, 10 \mathrm{~min}\right)$. The product tert-butyl (1-(6-amino-5(2,3-dichloro-5-((1-((2-(2,6-dioxopiperidin-3-yl)-1,3-dioxoisoindolin-4-yl)oxy)-2-oxo6,9,12,15,18-pentaoxa-3-azaicosan-20-yl)oxy)phenyl)pyrazin-2-yl)-4-methylpiperidin-4yl)carbamate (77.0 mg, $73.6 \mathrm{umol}, 78.4 \%$ yield) was obtained as a yellow solid.

To a solution of tert-butyl (1-(6-amino-5-(2,3-dichloro-5-((1-((2-(2,6-dioxopiperidin-3yl)-1,3-dioxoisoindolin-4-yl)oxy)-2-oxo-6,9,12,15,18-pentaoxa-3-azaicosan-20yl)oxy)phenyl)pyrazin-2-yl)-4-methylpiperidin-4-yl)carbamate (77.0 mg, 73.6 umol, $1.00 \mathrm{eq})$ in EtOAc $(1.00 \mathrm{~mL})$ was added $\mathrm{HCl} / \mathrm{EtOAc}(4 \mathrm{M}, 184 \mathrm{uL}, 10.0 \mathrm{eq})$. The mixture was stirred at 15 ${ }^{\circ} \mathrm{C}$ for $2 \mathrm{~h}$. The reaction mixture was filtered and concentrated under reduced pressure to give a residue. The residue was purified by prep-HPLC ( $\mathrm{HCl}$ condition: column: Phenomenex Synergi C18 150*25*10um; mobile phase: [water $(0.05 \% \mathrm{HCl})$ - acetonitrile]; $\mathrm{B} \%$ : 23\%-43\%, $11 \mathrm{~min})$. The product compound S9-4c (33.6 mg, 33.9 umol, 46.1\% yield, 99.1\% purity, $\mathrm{HCl}$ ) was obtained as a yellow solid. 


\section{Scheme 6}<smiles>Cc1nc(N2CCC3(CC2)CO[C@@H](C)[C@H]3NCC(=O)OCc2ccccc2)c(CO)nc1Br</smiles>

S6-1<smiles>Cc1nc(N2CCC3(CC2)CO[C@@H](C)[C@H]3NC(=O)O)c(CO)nc1-c1ccc(O)c(Cl)c1Cl</smiles>

Intermediate $\mathbf{X}$

1.

Intermediate 2 TSTU, DIPEA, DMF

2. $\mathrm{MsCl}, \mathrm{TEA}, \mathrm{DMF}, 0^{\circ} \mathrm{C}, 12 \mathrm{~h}$<smiles>COCCOCCOCCOCCNC(=O)COc1cccc2c1C(=O)N(C1CCC(=O)NC1=O)C2=O</smiles>

1. Intermediate $\mathrm{X}, \mathrm{K}_{2} \mathrm{CO}_{3}$, acetone, $\mathrm{rt}, \mathrm{o} / \mathrm{n}$

or

or $\mathrm{K}_{3} \mathrm{CO}_{3}, \mathrm{KI}$, TBAI,

R1-5c

$\mathrm{ACN}, 50^{\circ} \mathrm{C}, 3 \mathrm{~h}$

2. TFA, DCM, rt

\section{Tert-butyl ((3S,4S)-8-(5-(2,3-dichloro-4-hydroxyphenyl)-3-(hydroxymethyl)-6-}

\section{methylpyrazin-2-yl)-3-methyl-2-oxa-8-azaspiro[4.5]decan-4-yl)carbamate (Intermediate}

X): The mixture of previously reported ${ }^{14}$ tert-butyl N-[(3S,4S)-8-[5-bromo-3-(hydroxymethyl)-

6-methylpyrazin-2-yl]-3-methyl-2-oxa-8-azaspiro[4.5]decan-4-yl]carbamate (480 mg, 1.02

mmol, 1.00 equiv), 2,3-dichloro-4-(4,4,5,5-tetramethyl-1,3,2-dioxaborolan-2-yl)phenol (359 mg,

$1.24 \mathrm{mmol}, 1.22$ equiv), $\mathrm{K}_{2} \mathrm{CO}_{3}$ (432 mg, $3.13 \mathrm{mmol}, 3.07$ equiv) and $\mathrm{Pd}(\mathrm{dppf}) \mathrm{Cl}_{2}$ (97 mg, 0.132

mmol, 0.13 equiv) in $\mathrm{EtOH}(12 \mathrm{~mL})$ and water $(2.4 \mathrm{~mL})$ was stirred for $3 \mathrm{~h}$ at $80^{\circ} \mathrm{C}$ under a

nitrogen atmosphere. The mixture was allowed to cool to room temperature. The reaction was

quenched by the addition of water $(30 \mathrm{~mL})$. The resulting mixture was extracted with DCM $(3 \mathrm{x}$ 
$30 \mathrm{~mL})$. The combined organic layers were washed with brine $(30 \mathrm{~mL})$, dried over anhydrous

$\mathrm{Na}_{2} \mathrm{SO}_{4}$. After filtration, the filtrate was concentrated under reduced pressure. The residue was purified by silica gel column chromatography, eluted with DCM / MeOH (9:1) to afford tertbutyl N-[(3S,4S)-8-[5-(2,3-dichloro-4-hydroxyphenyl)-3-(hydroxymethyl)-6-methylpyrazin-2yl]-3-methyl-2-oxa-8-azaspiro[4.5]decan-4-yl]carbamate (Intermediate X, $400 \mathrm{mg}, 60 \%$ ) as a brown solid.

General synthesis of S6-2. Exemplified for $\mathbf{n}=\mathbf{1}$. To a stirred mixture of Intermediate 2 (6.50 g, $19.56 \mathrm{mmol}, 1.00$ equiv) and TSTU (8.8 g, $29.34 \mathrm{mmol}, 1.50$ equiv) in DMF (65 mL) was added DIPEA (5.0 g, $39.12 \mathrm{mmol}, 2.00$ equiv) dropwise at $0{ }^{\circ} \mathrm{C}$ under a nitrogen atmosphere. The resulting mixture was stirred for overnight at room temperature. The reaction was quenched with water/ice at room temperature. The resulting mixture was extracted with EtOAc $(3 \times 100 \mathrm{~mL})$. The combined organic layers were washed with brine $(100 \mathrm{~mL})$, dried over anhydrous $\mathrm{Na}_{2} \mathrm{SO}_{4}$. After filtration, the filtrate was concentrated under reduced pressure. This resulted in 2,5-dioxopyrrolidin-1-yl 2-[[2-(2,6-dioxopiperidin-3-yl)-1,3dioxoisoindol-4-yl]oxy]acetate $(4.0 \mathrm{~g}, 38 \%)$ as a white solid.

To a stirred mixture of 2,5-dioxopyrrolidin-1-yl 2-[[2-(2,6-dioxopiperidin-3-yl)-1,3dioxoisoindol-4-yl]oxy]acetate (2.00 g, $4.65 \mathrm{mmol}, 1.00$ equiv) and 2-[2-[2-(2aminoethoxy)ethoxy]ethoxy]ethanol ( $0.90 \mathrm{~g}, 4.65 \mathrm{mmol}, 1.00$ equiv) in DMF (20 mL) was added DIEA $\left(1.20 \mathrm{~g}, 9.27 \mathrm{mmol}, 1.99\right.$ equiv) dropwise at $0{ }^{\circ} \mathrm{C}$ under a nitrogen atmosphere. The resulting mixture was stirred overnight at room temperature. The reaction mixture was purified by reverse flash chromatography [column, C18 silica gel; mobile phase, acetonitrile in water $(0.1 \%$ formic acid), $0 \%$ to $70 \%$ gradient in 10 min; detector, UV $254 \mathrm{~nm}$ ] to give 2-[[2-(2,6-dioxopiperidin-3-yl)-1,3-dioxoisoindol-4-yl]oxy]-N-(2-[2[2-(2-hydroxyethoxy)ethoxy]ethoxy]ethyl)acetamide (1.1 g, 46\%) as a light yellow oil.

To a stirred mixture of 2-[[2-(2,6-dioxopiperidin-3-yl)-1,3-dioxoisoindol-4-yl]oxy]-N-(2-[2-[2(2-hydroxyethoxy)ethoxy]ethoxy]ethyl)acetamide ( $1.60 \mathrm{~g}, 0.31 \mathrm{mmol}, 1.00 \mathrm{equiv})$ and TEA (0.96 g, 0.95 
mmol, 3.0 equiv) in DMF $(16 \mathrm{~mL})$ was added $\mathrm{MsCl}\left(0.55 \mathrm{~g}, 0.46 \mathrm{mmol}, 1.51\right.$ equiv) dropwise at $0{ }^{\circ} \mathrm{C}$.

The resulting mixture was stirred for $12 \mathrm{~h}$ at room temperature. The residue was purified by reverse flash chromatography [column, $\mathrm{C} 18$ silica gel; mobile phase, acetonitrile in water $(0.1 \%$ formic acid), $0 \%$ to $70 \%$ gradient in $40 \mathrm{~min}$; detector, UV $254 \mathrm{~nm}]$ to give 2-(2-[2-[2-(2-[[2-(2,6-dioxopiperidin-3-yl)-1,3dioxoisoindol-4-yl]oxy]acetamido)ethoxy]ethoxy] ethoxy)ethyl methanesulfonate (S6-2 n = 1, $840 \mathrm{mg}$, $45 \%)$ as a light yellow oil.

General synthesis of R1-1c, R1-3c and R1-5c. Exemplified for R1-1c. To a stirred mixture of Intermediate $\mathbf{X}$ (100 mg, $0.18 \mathrm{mmol}, 1.00$ equiv) and $\mathbf{S 6 - 2} \mathbf{n}=\mathbf{1}(106 \mathrm{mg}, 0.18 \mathrm{mmol}, 1.00$ equiv) in acetone $(10 \mathrm{~mL})$ were added $\mathrm{K}_{2} \mathrm{CO}_{3}(75 \mathrm{mg}, 0.54 \mathrm{mmol}, 3.0$ equiv) in portions at room temperature under a nitrogen atmosphere. The resulting mixture was stirred overnight at room temperature under a nitrogen atmosphere. The resulting mixture was purified by reverse flash chromatography [column, C18 silica gel; mobile phase, acetonitrile in water ( $0.1 \%$ formic acid), $10 \%$ to $80 \%$ gradient in $30 \mathrm{~min}$; detector, UV 254 $\mathrm{nm}]$. The collected fraction was lyophilized to afford tert-butyl N-[(3S,4S)-8-(5-[2,3-dichloro-4-[2-(2-[2[2-(2-[[2-(2,6-dioxopiperidin-3-yl)-1,3-dioxoisoindol-4-

yl]oxy]acetamido)ethoxy]ethoxy]ethoxy)ethoxy]phenyl]-3-(hydroxymethyl)-6-methylpyrazin-2-yl)-3methyl-2-oxa-8-azaspiro[4.5]decan-4-yl]carbamate (84 $\mathrm{mg}, 22 \%)$ as a white solid.

To a stirred mixture of tert-butyl N-[(3S,4S)-8-(5-[2,3-dichloro-4-[2-(2-[2-[2-(2-[[2-(2,6dioxopiperidin-3-yl)-1,3-dioxoisoindol-4-yl]oxy]acetamido)ethoxy]ethoxy]ethoxy)ethoxy]phenyl]-3(hydroxymethyl)-6-methylpyrazin-2-yl)-3-methyl-2-oxa-8-azaspiro[4.5]decan-4-yl]carbamate (40 mg, $0.04 \mathrm{mmol}, 1.00$ equiv) in DCM $(4 \mathrm{~mL})$ were added TFA $(0.80 \mathrm{~mL})$ in portions at room temperature under a nitrogen atmosphere. The resulting mixture was stirred for $3 \mathrm{~h}$ at room temperature under a nitrogen atmosphere. The resulting mixture was concentrated and the residue was purified by reverse flash chromatography [column, C18 silica gel; mobile phase, acetonitrile in water $(0.1 \%$ formic acid), $10 \%$ to $50 \%$ gradient in $30 \mathrm{~min}$; detector, UV $254 \mathrm{~nm}$ ]. The crude product (40 mg) was purified by PrepHPLC [column: Xselect CSH OBD Column 30x150mm 5um, n; Mobile Phase A: water ( $0.1 \%$ formic 
acid), Mobile Phase B: acetonitrile; flow rate: $60 \mathrm{~mL} / \mathrm{min}$; Gradient: 20 B to 34 B in $7 \mathrm{~min} ; 220 \mathrm{~nm}$ ]. The collected fraction was lyophilized to afford R1-1c (21 mg, 56\%) as a white solid.

\section{NMR spectroscopy}

All ${ }^{1} \mathrm{H}$ NMR spectra were acquired at $600 \mathrm{MHz}$ at $25^{\circ} \mathrm{C}$ and chemical shifts are represented in $\delta$ scale. Residual protium in the NMR solvent $\left(\mathrm{MeOH}-d_{4}, \delta 3.31\right)$ was used to reference chemical shifts. Data are represented as follows: assignment, chemical shift, integration, multiplicity (s, singlet; $d$, doublet; $t$, triplet; $m$, multiplet), and coupling constant in Hertz. All ${ }^{13} \mathrm{C}$ NMR spectra were obtained at $150 \mathrm{MHz}$ at $25^{\circ} \mathrm{C}$ and chemical shifts are represented in $\delta$ scale. The carbon resonances of the NMR solvent $\left(\mathrm{MeOH}-d_{4}, \delta 49.15\right)$ are used to reference chemical shifts. Full assignment of protons and carbons were completed on the basis of the following two-dimensional NMR spectroscopy experiments: ${ }^{1} \mathrm{H}-{ }^{1} \mathrm{H}$ correlation spectroscopy (COSY), ${ }^{1} \mathrm{H}-{ }^{13} \mathrm{C}$ heteronuclear single quantum coherence non-uniform sampling (HSQC-NUS), ${ }^{1} \mathrm{H}-{ }^{13} \mathrm{C}$ heteronuclear multiple bond connectivity non-uniform sampling (HMBC-NUS) (Tables S2-S9 and Figures S11-S50).

\section{LC-MS}

Samples were separated over a Kinetex C18 column with water $+0.1 \%$ formic acid $(A)$ and acetonitrile $+0.1 \%$ formic acid $(B)$ as mobile phases. After an initial equilibration period 3 minutes at $5 \% \mathrm{~B}$, a linear gradient to $100 \%$ was run over 13 minutes. The LC stream was inline with an Agilent 6530 qTOF with standard parameters (Table S10 and Figures S51-S57).

\section{Antibodies and compounds}

Antibodies used in this study were obtained commercially from the following sources: SHP2 (Bethyl, \#A301-544A), Phospho-Thr202/Tyr204-Erk1/2 (CST, \#9101), Cereblon (CST, \#71810), $\beta$-actin (Millipore-Sigma, \#A1978), $\beta$-tubulin (CST, \#2146), GAPDH (CST, \#5174).

SHP099 and RMC-4550 were purchased from DC chemicals (Catalog No. DC9737) and ProbeChem Biochemicals (Catalog No. PC-35116), respectively. 6,8-Difluoro-4- 
Methylumbelliferyl Phosphate (DiFMUP, \#D22065) and 6,8-difluoro-7-hydroxy-4-methylcoumarin (DiFMU, \#D6566) were purchased from Life Technologies.

\section{Cell culture}

The MV-4-11 cell line were purchased from the American Type Culture Collection (ATCC). The KYSE-520 and MOLM-13 cell lines were purchased from DSMZ (Braunschweig, Germany). Parental and CRBN knockout MOLT4 cells were a gift from Dr. Nathanael Gray (Dana-Farber Cancer Institute). All cell lines were cultured in RPMI-1640 media containing 10\% FBS and 1\% penicillin-streptomycin at $37^{\circ} \mathrm{C}$ with $5 \% \mathrm{CO} 2$.

\section{Immunoblotting analysis}

Cells were treated with PROTAC compounds as indicated and lysed in RIPA lysis buffer (25 mM Tris- $\mathrm{HCl}(\mathrm{pH} 7.6), 150 \mathrm{mM} \mathrm{NaCl}, 1 \%$ Nonidet P-40, 1\% Sodium deoxycholate, $0.1 \%$ Sodium dodecyl sulfate, 2 mM EDTA) with protease inhibitors (cOmplete Mini, Roche). Lysates were resolved on SDS-PAGE gels (Novex Tris-Glycine, ThermoFisher Scientific) and transferred to PVDF membranes using the XCell II wet blotting system (ThermoFisher Scientific). Membranes were blocked with 5\% BSA diluted in TBST (Tris-buffered saline, 0.1\% Tween 20) buffer and incubated with primary antibodies overnight. The blots were rinsed three times for 10 minutes each in $15 \mathrm{ml}$ of TBST buffer and incubated with secondary antibodies diluted with $5 \%$ BSA for 1 $\mathrm{h}$ followed by three final washes. Specific protein bands were detected using SuperSignal ${ }^{\mathrm{TM}}$ West Pico PLUS Chemiluminescent Substrate (ThermoFisher Scientific).

\section{Measurement of inhibitory activity of compounds using DiFMUP}

The phosphatase activities of SHP2-F285S and the isolated PTP domain were measured using the fluorogenic small molecule substrate, DiFMUP. Compounds were dissolved in DMSO at $10 \mathrm{mM}$ concentration, diluted 1:10 in assay buffer $(60 \mathrm{mM}$ Hepes $\mathrm{pH}$ 7.2, $75 \mathrm{mM} \mathrm{KCl,} 75 \mathrm{mM}$ $\mathrm{NaCl}, 1 \mathrm{mM}$ EDTA, 0.05\% Tween-20, and $2 \mathrm{mM} \mathrm{DTT)} \mathrm{and} \mathrm{added} \mathrm{to} \mathrm{96-well} \mathrm{plates} \mathrm{in} \mathrm{a} \mathrm{3-fold}$ 
dilution (concentration range $200 \mu \mathrm{M}-3.3 \mathrm{nM}$ ) in triplicate. Serially diluted compound was mixed with $0.5 \mathrm{nM}$ SHP2-F285S mutant or isolated PTP domain proteins and incubated at room temperature for $1 \mathrm{~h}$, after which $400 \mu \mathrm{M}$ DiFMUP was added to each well. $1 \mathrm{~h}$ after DiFMUP addition, fluorescence was measured on a SpectraMax M5 plate reader (Molecular Devices) using excitation and emission wavelengths of 340nm and $450 \mathrm{~nm}$ and the inhibitor dose-response curves were analyzed using non-linear regression curve fitting with control based normalization.

\section{Cell viability analysis}

MV-4-11 cells were seeded at 1000 cells per $\mathrm{ml}$ of media in $10 \mathrm{~cm}$ plates in triplicate and treated with 100 nM R1-5C, 100 nM R1-1C, 100 nM RMC-4550 or DMSO carrier. The cells were replenished with compounds every $24 \mathrm{~h}$ and counted on days 1-9 using automated cell counter (Bio-Rad). KYSE-520 cells were plated onto 96-well plates (500 cells per well) in $100 \mu$ medium and treated with 100 nM R1-5C, 100 nM RMC-4550 or DMSO carrier. The cells were replenished with compounds every $24 \mathrm{~h}$ and cell viability was assessed on days $1,3,5,7,9$ by adding $20 \mu \mathrm{l}$ CellTiter-Blue reagent (Promega) to wells and measuring luminescent signal using GloMax discover microplate reader (Promega).

\section{TMT-based LC-MS3 proteomics}

MV-4-11 cells (10 M) were treated with DMSO carrier or 100 nM R1-5C, 100 nM R1-3C, 100 nM R1-1C, 100 nM RMC-4550, $1 \mu$ M pomalidomide in biological duplicate or singlicate for the indicated time periods. MOLT4 cells $(5 \mathrm{M})$ were treated with $1 \mu \mathrm{M}$ R1-5C for $5 \mathrm{~h}$ in biological singlicate. Cells were then harvested by centrifugation and cell pellets snap frozen in liquid Nitrogen. Sample preparation for TMT LC-MS3 mass spectrometry were performed as described previously ${ }^{15}$.

\section{Expression and purification of wildtype SHP2, F285S-SHP2 and isolated PTP domain}


Human wild-type SHP2 (1-525 aa, UniProtKB: Q06124) was inserted into a modified pGEX6P1 vector with an N-terminal GST tag, followed by a PreScission cleavage site. Recombinant GSTSHP2 protein was overexpressed in E.coli BL21 (DE3) cells induced by $0.2 \mathrm{mM}$ isopropyl-1-thioD-galactopyranoside (IPTG) at $16^{\circ} \mathrm{C}$ overnight. Cells were harvested by centrifugation, resuspended in lysis buffer $(25 \mathrm{mM}$ Tris 7.5, $150 \mathrm{mM} \mathrm{NaCl}, 2 \mathrm{mM} \mathrm{MgCl}$, $2 \mathrm{mM}$ TCEP and an EDTA-free protease inhibitor cocktail tablet (cOmplete, Roche)) and lysed by sonication. After centrifugation, the recombinant GST-SHP2 in supernatant was affinity-purified by Pierce glutathione agarose (Thermo Fisher Scientific) and eluted with lysis buffer containing $20 \mathrm{mM}$ GSH. After GST tag cleavage with the recombinant HRV 3C protease, the SHP2 protein was further purified by HiTrap Heparin HP column (GE Healthcare). SHP2 containing fractions were pooled and finally polished over a Superdex200 10/300 GL size exclusion column (GE Healthcare) in buffer containing $25 \mathrm{mM}$ Tris 7.5, $100 \mathrm{mM} \mathrm{NaCl}, 2$ mM MgCl2, 2 mM TCEP. Protein sample concentration was determined based on the UV absorbance at $280 \mathrm{~nm}$. Wildtype SHP2 protein was concentrated to $18 \mathrm{mg} / \mathrm{ml}$ for crystallization. SHP2-F285S and isolated PTP domain proteins were expressed and purified as described previously ${ }^{8}$.

\section{Crystallization and structure determination}

The hanging-drop vapor diffusion method was used for co-crystallization of wild-type SHP2 in complex with RMC-4550. Wild-type SHP2 was incubated with RMC-4550 at a molar ratio of $1: 2$ and crystals were grown at $18^{\circ} \mathrm{C}$ by mixing equal volumes of the protein sample and reservoir solution (0.1 M Sodium Chloride, 0.1 M BIS-TRIS propane pH 8.5, 11\% PEG 1500). Diffraction quality crystals were cryoprotected by supplementing reservoir solution with $20 \%$ glycerol and flash frozen in liquid nitrogen. X-Ray diffraction collection was performed at the Advanced Photon Source NE-CAT beamline 24 ID-E at $100 \mathrm{~K}$ using a wavelength of $0.979 \AA$. The diffraction images from single crystals were processed and scaled using $\mathrm{XDS}^{16}$. To obtain phases, molecular replacement for both copies of SHP2 in the unit cell was performed in Phenix 
with Phaser using chain B of a SHP2 crystal structure (PDB ID 5EHR) as the search model. Iterative model building was performed in $\mathrm{COOT}^{17}$. Reciprocal space refinement was performed in phenix.refine, using reciprocal space optimization of xyz coordinates, individual atomic Bfactors, NCS restraints, optimization for X-ray/stereochemistry weights, and optimization for Xray/ADP weights ${ }^{18}$. The RMC-4550 ligand coordinate and restraint file were generated using $\mathrm{eLBOW}^{19}$. In the final cycles of model building, NCS restraints were removed during refinement and overall model quality was assessed using MolProbity ${ }^{20}$. All crystallographic data processing, refinement, and analysis software was compiled and supported by the SBGrid Consortium ${ }^{21}$.

\section{Real-time quantitative PCR}

1 million cells were treated with R1-5C at [add concentration] or DMSO for 2 or 16 hours. Cells were harvested after treatment in TRIzol (Thermo Fisher), and RNA was purified by phenolchloroform extraction using MaXtract high density tubes (Qiagen). RNA was treated with Turbo DNase (Thermo Fisher) for 30 minutes at 37C, then re-extracted with chloroform isoamyl alcohol using MaXtract high density tubes. $1 \mu \mathrm{g}$ of RNA for each sample was used to make cDNA using the iScript cDNA synthesis kit (Bio-Rad). qPCR was performed using PowerUp SYBR Green Master Mix (Thermo Fisher) in a $10 \mu \mathrm{L}$ total reaction with $0.25 \mu \mathrm{M}$ forward and reverse primers, with two technical replicates per experiment. Primer sequences are shown in table XX Expression was normalized to the average of GAPDH and $\beta$-Actin expression. Significant differences were identified using Welch's t-test in PRISM 9.0.2.

Primer sequence table:

\begin{tabular}{|l|l|l|}
\hline Target & Forward primer sequence & Reverse primer sequence \\
\hline DUSP6 set $A$ & CAGCGACTGGAACGAGAATAC & GAACTCGGCTTGGAACTTACT \\
\hline DUSP6 set $\mathrm{B}^{22}$ & AGCAGCGACTGGAACGAGAA & TGTTGGACAGCGGACTACCAT \\
\hline GAPDH & CTTCACCACCATGGAGGAGGC & GGCATGGACTGTGGTCATGAG \\
\hline
\end{tabular}




\begin{tabular}{|l|l|l|}
\hline$\beta$-Actin & CAACCGCGAGAAGATGACC & AGCCTGGATAGCAACGTACA \\
\hline
\end{tabular}

\section{Results}

The CRBN E3 ligase ligands (pomalidomide, lenalidomide and thalidomide, collectively referred to as IMiDs) have been successfully employed in the design of a wide range of PROTACs to degrade various proteins ${ }^{23-26}$. In order to develop an effective SHP2 PROTAC, therefore, we first designed a series of compounds designed to tether SHP099 to the IMiD pomalidomide. We chose pomalidomide as our E3 ligase ligand because it has higher cellular stability compared to other IMiDs ${ }^{27}$.

To guide the sites for attachment of the linker to the SHP099 warhead, we relied on the X-ray structure of SHP2-SHP099 complex (PDB code 5EHR), which shows that there is an exit path for the linker when coupled at either of two positions on the dichloro-substituted aromatic ring (Figure S1A). Two different linker strategies were therefore employed, using either aliphatic or ether attachments to the SHP099 warhead (Figures S1B-E).

We tested whether any of these compounds catalyzed degradation of SHP2 in the MV411 acute myeloid leukemia cell line. When MV4-11 cells were treated with these compounds at doses ranging from $0.01 \mu \mathrm{M}$ to $50 \mu \mathrm{M}$, there was no evidence of SHP2 degradation for any of the compounds, as judged by western blot (Figure S2A).

Because none of these first-generation compounds resulted in SHP2 degradation, we determined whether the conjugation of pomalidomide to the SHP099 warhead affected the inhibitory potency of the parent SHP099 compound. We compared the inhibitory activity of SHP099 with the various SHP099-pomalidomide conjugates in enzymatic assays with purified protein, using the fluorogenic substrate DiFMUP and the weakly active SHP2 mutant F285S. 
Upon titration of SHP099, the F285S enzyme showed a dose-dependent inhibition of phosphatase activity with a half maximal inhibitory concentration $\left(\mathrm{IC}_{50}\right)$ of $62 \mathrm{nM}$, similar to our previous findings ${ }^{28}$ for its IC50, and similar to the $K_{D}$ values for wild-type SHP2 ${ }^{4}$. In contrast, the inhibitory profiles of the SHP099-IMiD conjugates are right-shifted, with $\mathrm{IC}_{50}$ values ranging from $0.5 \mu \mathrm{M}$ to $3.7 \mu \mathrm{M}$ (Figure S2B), indicating that the coupling of the linker to the warhead reduces inhibitory potency between roughly $10-100$ fold, depending on the site of attachment and the nature of the linkage. In fact, simply installing a PEG chain on SHP099 caused a 10-fold decrease in inhibitory activity in vitro and in cells (Figures S3A-S3C). Together, these findings revealed that coupling the linker to the warhead results in a minimum $\sim 10$-fold reduction in potency, and suggested that an active PROTAC would require a more potent warhead to offset this consequence of linker coupling.

RMC-4550 is an allosteric inhibitor of SHP2 (Figure 1A) with a 50-fold higher potency than SHP099 in vitro ${ }^{12}$. To determine whether a similar exit path for the linker exists for RMC4550 bound to SHP2, we determined the structure of RMC-4550 bound to wild-type SHP2 by xray crystallography to $1.8 \AA$ resolution (Figure $\mathbf{1 A}$, Table S1). The structure shows that the dichlorophenyl ring of RMC-4550 adopts virtually the identical pose as that of SHP099 when bound, exposing the same tethering sites to solvent for the design of PROTAC compounds (Figure S4A,B).

Since S9-3C is the most potent of all SHP099-IMiD conjugates, we substituted SHP099 with RMC-4550 in this design to create R1-3C (Figure 1B). Upon titration of R1-3C, the SHP2 mutant F285S showed a dose-dependent inhibition of phosphatase activity with an $\mathrm{IC}_{50}$ of $14 \mathrm{nM}$ (Figure 2A), a roughly 10-fold reduction compared to RMC-4550 $\left(\mathrm{IC}_{50}=1.5 \mathrm{nM}\right)$. As expected, this compound displayed no inhibitory activity towards the free catalytic domain (PTP).

We treated MV4;11 cells with increasing doses of R1-3C or with DMSO carrier as a control for $24 \mathrm{~h}$ and measured SHP2 protein levels by Western blotting. We observed a dose-dependent 
decrease in SHP2 levels with maximal degradation at $100 \mathrm{nM}$ (Figure 2B). The loss of activity observed at higher R1-3C concentrations $(1 \mu \mathrm{M}, 10 \mu \mathrm{M}$ and $50 \mu \mathrm{M})$, referred to as a hook effect, is a signature trait of PROTACs.

Because the length of the linker plays a key role in the potency of PROTACs ${ }^{29-32}$, we varied the linker lengths between RMC-4550 and pomalidomide to search for a PROTAC with higher potency. Extension of the linker with two additional PEG units (R1-5C in Figures 1B, 2C, S5A) resulted in a PROTAC with greater potency, whereas shortening the linker by two PEG units (R1-1C in Figures 1B, 2C) caused complete loss of PROTAC activity.

To determine the kinetics of R1-5C mediated degradation of SHP2 in MV4-11 cells, we assessed SHP2 protein abundance at a series of time points after compound addition. SHP2 levels are substantially reduced within $6 \mathrm{~h}$ after R1-5C treatment, reaching maximal depletion after $16 \mathrm{~h}$ (Figure 3A). SHP2 remains depleted at $24 \mathrm{~h}$; however, it reaccumulates to pretreatment levels by 48h (Figure S5B), consistent with cellular half-lives observed for other PROTACs ${ }^{23}$.

We confirmed the dependence of SHP2 depletion on the CRBN E3 ligase by comparing the degradation activity of our PROTAC compounds in parental MOLT4 and CRBN ${ }^{-/-}$knockout $^{-1}$ cells. Whereas PROTAC treatment reduced SHP2 protein abundance in MOLT4 parental cells, PROTAC-dependent degradation of SHP2 was not detectable in $\mathrm{CRBN}^{-/}$cells, confirming the CRBN requirement for PROTAC activity (Figures 3B, S5C).

We then performed time-resolved quantitative proteomics to further evaluate the selectivity of these compounds for SHP2 and to determine the kinetics of SHP2 degradation in MV4;11 cells. The cells were treated with R1-5C (100 nM for 2, 4, 8, or $16 \mathrm{~h}$ ) R1-3C (100 nM for 4 or $16 \mathrm{~h}$ ), R1-1C (100 nM for 4 or 16 h), RMC-4550 (R1-1C (100 nM for for $16 \mathrm{~h}$ ), pomalidomide $(1 \mu \mathrm{M}$ for $5 \mathrm{~h})$ or a vehicle control (DMSO) and protein abundance was measured quantiatively 
using 16-plex tandem mass tag (TMT) isobaric labels, as described previously ${ }^{15}$. R1-5C exhibits striking specificity for degradation of SHP2, which is evident within $4 \mathrm{~h}$ (Figure 4). At $16 \mathrm{~h}$ many of the secondary effects of SHP2 depletion recapitulate the consequence of allosteric inhibition (proteins labeled in blue in Figures 4C, 4D, highlighted with yellow dots in Figure S6), providing further evidence of the SHP2 specificity of the R1-5C PROTAC. By comparison, R13C, which has a shorter linker, resulted in more moderate SHP2 depletion at 16 h (Figure S7A), and R1-1C did not induce SHP2 degradation even at $16 \mathrm{~h}$, as anticipated (Figure S7B). Pomalidomide-induced degradation of classical IMiD targets (IKZF1 and ZFP91) serves as a positive control and validates the authenticity of the proteomics experiment (Figures 4E and S7C). Quantitative proteomics of MOLT4 cells treated with R1-5C compared to DMSO control after $5 \mathrm{~h}$ also showed that SHP2 is the only protein significantly reduced in abundance in MOLT4 cells (Figure S8).

To assess the time-dependent recovery of SHP2 protein abundance, we treated MV4-11 cells with $100 \mathrm{nM} \mathrm{R1-5C}$ for $24 \mathrm{~h}$, washed out the compound, and lysed cells at various time points after washout for immunoblotting. SHP2 protein abundance recovered to basal (DMSOtreated) levels $24 \mathrm{~h}$ after washout (Figure S9).

We also examined whether R1-5C affects MAPK signaling. We treated KYSE-520 cells with R1-5C or DMSO carrier and monitored the levels of DUSP6 transcript, a commonly used pharmacodynamic marker for MAPK pathway activity downstream of SHP2 ${ }^{4}$. Cells treated with R1-5C showed significant downregulation of DUSP6 mRNA amounts (Figures 5A and S10). Suppression of DUSP6 transcript abundance is observed both at $2 \mathrm{~h}$ and $16 \mathrm{~h}$ after treatment; the reduction at the late time point reports on the effect of SHP2 degradation on DUSP6 mRNA amounts, whereas the reduction at the $2 \mathrm{~h}$ time point indicates that allosteric inhibition of SHP2 by the RMC-4550 warhead is ongoing prior to SHP2 depletion. The inhibition of cancer cells by R1-5C was also assessed in a cell proliferation assay, which showed that R1-5C significantly 
inhibits KYSE-520 and MV4;11 cell growth, with an inhibitory effect comparable to that of RMC4550 (Figures 5B and 5C).

\section{Discussion}

We report here the design and evaluation of R1-5C, a potent and highly selective SHP2 PROTAC featuring an SHP2 allosteric site-binding warhead and the CRBN-targeting IMiD pomalidomide. R1-5C expands the range of PROTACs targeting SHP2, which currently include a VHL-targeting PROTAC ${ }^{33}$ and the Novartis clinical candidate TNO155 coupled to thalidomide 34.

Key features required for the degradative activity of our designed compound include the warhead coupling site, the linker chemistry, and the linker length. The high degree of selectivity of R1-5C for SHP2 has been documented in this study using stringent whole proteome analysis in two different cell lines, MV4;11 (Figure 4) and MOLT4 (Figure S8). In both of these lines, SHP2 (gene name PTPN11) is the only protein that shows a statistically significant reduction in abundance at time points from 4-8 hours, before secondary effects of SHP2 inhibition can be observed. By comparison, the selectivity of other reported SHP2-targeting PROTACS has not yet been assessed using whole proteomic studies ${ }^{33,34}$.

Whereas some IMiD-dependent PROTACs can induce detectable degradation of target proteins within $0.5 \mathrm{~h}$, several hours of treatment with $\mathrm{R} 1-5 \mathrm{C}$ are required before significant depletion of SHP2 is observed in either cell line. Although the origin of the slower onset of SHP2 degradation is not clear, the other recently reported, SHP2-targeting PROTACs also exhibit similar degradation kinetics based on Western blot analysis, independent of whether degradation is mediated by $\mathrm{VHL}^{33}$ or $\mathrm{CRBN}^{34}$. 
$\mathrm{R} 1-5 \mathrm{C}$ and related compounds are poised to serve as useful tools to investigate physiological roles of SHP2. An important question to be addressed in future work is whether R1$5 \mathrm{C}$ can be optimized to power degradation of oncogenic, mutant forms of SHP2. Such SHP2 PROTACs would then extend compound efficacy beyond RTK and ERK-dependent cancers that harbor wild-type SHP2 to cancers with mutant SHP2 and to patients with human genetic disorders like Noonan and LEOPARD syndromes.

Acknowledgments: We thank Jon Aster members of the Blacklow laboratory for helpful discussions.

Funding: This work was supported by Harvard Medical School's Q-FASTR program (S.C.B.) and NIH award R35 CA220340 (S.C.B.).

Competing interests: SCB is a member of the SAB of Erasca, Inc., is an advisor to MPM Capital, and is a consultant on unrelated projects for IFM, Scorpion Therapeutics, and Ayala Therapeutics.

Data availability: Diffraction data and refined coordinates have been deposited in the Protein Data Bank under accession code XXX. 


\section{Figure Legends}

Figure 1. Structure of SHP2 protein in complex with RMC-4550. (A) Chemical structure of RMC-4550 and X-ray crystal structure of SHP2 in complex with RMC-4550 (PDB code XXX). Surface representation of SHP2 in complex with RMC-4550 bound in the central tunnel formed at the interface of N-SH2 (green), $\mathrm{C}-\mathrm{SH} 2$ (blue) and PTP (wheat) domains. (B) Chemical structures of RMC-4550-based PROTAC candidates, R1-1C, R1-3C and R1-5C.

Figure 2. SHP2 degradation induced by RMC-4550-based PROTACs. (A) Inhibition of SHP2F285S- or PTP-mediated DIFMUP dephosphorylation by R1-1C, R1-3C, R1-5C and RMC-4550. MV4;11 cells were treated with increasing doses of R1-3C (B), R1-1C or R1-5C (C) for $24 \mathrm{~h}$ and subjected to Western blotting using SHP2, GAPDH and $\beta$-actin antibodies.

Figure 3. Cell-based evaluation of R1-5C. (A) Time course of SHP2 degradation by R1-5C (100 $\mathrm{nM}$ ) in MV4;11 cells. Immunoblotting with SHP2 and $\beta$-actin antibodies. (B) $\mathrm{CRBN}^{-/-}$and parental MOLT4 cells were treated with increasing doses of R1-5C for $24 \mathrm{~h}$ and subjected to Western blotting using SHP2, CRBN and $\beta$-actin antibodies

Figure 4. Proteomics analysis showing selective SHP2 degradation by R1-5C. (A-D) Scatterplots displaying relative fold-change in SHP2 abundance following treatment of MV4;11 cells with 100 nM R1-5C for 4 h (A), 8 h (B), 16 h (C) or 100 nM RMC-4550 (D). SHP2/PTPN11 is highlighted in red. Hits highlighted in blue in (C) and (D) indicate changes in abundance of proteins at $16 \mathrm{~h}$ time point due to secondary effects (such as transcriptional responses) of SHP2 degradation or inhibition. (E) Heatmap of the protein abundance changes in MV4;11 cells comparing treatment with $100 \mathrm{nM}$ R1-1C (4 h and $16 \mathrm{~h}$ ), $100 \mathrm{nM} \mathrm{R1-3C} \mathrm{(4} \mathrm{h} \mathrm{and} 16 \mathrm{~h}), 100 \mathrm{nM}$ R1-5C (2 h, 4 h, $8 \mathrm{~h}$ and $16 \mathrm{~h}), 100 \mathrm{nM}$ RMC-4550 (16 h) and $1 \mu \mathrm{M}$ pomalidomide $(5 \mathrm{~h})$. The heatmap colors are scaled with red indicating a decrease in protein abundance ( $\left.-2 \log _{2} \mathrm{FC}\right)$ and blue indicating an increase $\left(2 \log _{2} \mathrm{FC}\right)$ in protein abundance. 
Figure 5. R1-5C inhibits MAPK signaling and suppresses cancer cell growth (A) Downregulation of DUSP6 transcript levels in KYSE-520 cells after $2 \mathrm{~h}$ and $16 \mathrm{~h}$ treatment with 200 nM R1-5C or DMSO carrier. DUSP6 mRNA was quantified by RT-qPCR using primer set B. (B and C) Cells were treated with 100 nM R1-5C, 100 nM RMC-4550 or DMSO carrier in triplicate and cell numbers were assessed at the indicated time points by automated cell counting (for MV4;11 cells) or CellTiter-Blue assay (for KYSE-520 cells).

Figure S1. Structure of SHP2 protein in complex with SHP099. (A) Chemical structure of SHP099 and X-ray crystal structure of SHP2 in complex with SHP099 (PDB code 5EHR). Surface representation of SHP2 in complex with SHP099 bound in the central tunnel formed at the interface of N-SH2 (green), C-SH2 (blue) and PTP (wheat) domains. (B-E) Chemical structures of SHP099-IMiD conjugates, S9-1C, S9-2C, S9-3C and S9-4C.

Figure S2: Evaluation of SHP099-IMiD conjugates. (A) MV4;11 cells were treated with increasing doses of S9-1C, S9-2C, S9-3C and S9-4C for $24 \mathrm{~h}$ and subjected to Western blotting using SHP2 and $\beta$-actin antibodies. (B) Inhibition of SHP2(F285S)- or PTP-catalyzed DIFMUP dephosphorylation by SHP099 and SHP099-IMiD conjugates.

Figure S3. Evaluation of SHP099-PEG 6 intermediate compound. (A) Chemical structures of SHP099 and SHP099-PEG 6 intermediate compound (SHP099-I34). (B) Inhibition of SHP2F285S-mediated DIFMUP dephosphorylation by SHP099 and SHP099-I34. (C) MV4;11 cells were treated with increasing doses of SHP099 and SHP099-I34 for 24 h and subjected to Western blotting using phospho-ERK1/2 and ERK1/2 antibodies.

Figure S4. Allosteric compound SHP2 binding pocket. A cross-section view of the SHP2 binding pocket with (A) RMC-4550 and (B) SHP099 reveals the extent of solvent exposure to the dichlorophenyl ring for both compounds. Surface representation of SHP2 is colored as in figure 1 
and interior colored in grey. The bound RMC-4550 and SHP099 compounds are shown in yellow sticks.

Figure S5. Cellular evaluation of RMC-4550-based PROTAC candidates. (A) MV4;11 cells were treated with DMSO carrier or increasing doses of R1-3C and R1-5C for $24 \mathrm{~h}$ and subjected to Western blotting using SHP2 and $\beta$-actin antibodies. (B) MV4;11 cells were treated with 100 nM R1-5C and cells were harvested after 1, 2, 3, 4, 5 or 6 days and subjected to immunoblotting using SHP2 and $\beta$-actin antibodies. (C) $\mathrm{CRBN}^{-/-}$and parental MOLT4 cells were treated with increasing doses of R1-3C for $24 \mathrm{~h}$ and subjected to Western blotting using SHP2, CRBN and $\beta$ tubulin antibodies.

Figure S6. Proteome-wide changes caused by SHP2 PROTAC compounds. Heatmap of the protein abundance changes in MV4;11 cells comparing treatment with R1-1C, R1-3C, R1-5C, RMC-4550 and pomalidomide. The heatmap colors are scaled with red indicating a decrease in protein abundance $\left(-2 \log _{2} \mathrm{FC}\right)$ and blue indicating an increase $\left(2 \log _{2} \mathrm{FC}\right)$ in protein abundance. The green dot marks fold-changes in SHP2 protein. The yellow dots represent changes in other proteins due to secondary effects (such as transcriptional responses) of SHP2 degradation or SHP2 inhibition at $16 \mathrm{~h}$ time points.

Figure S7. Proteomic profiling of R1-3C, R1-1C and pomalidomide. Scatterplots depicting relative fold-changes in protein abundances following treatment of MV4;11 cells with 100 nM R1$3 \mathrm{C}$ for $16 \mathrm{~h}(\mathrm{~A}), 100 \mathrm{nM} \mathrm{R} 1-1 \mathrm{C}$ for $16 \mathrm{~h}(\mathrm{~B})$ or $1 \mu \mathrm{M}$ pomalidomide for $5 \mathrm{~h}(\mathrm{C})$. SHP2/PTPN11 is highlighted in red in (A). Hits highlighted in blue in (A) and (B) indicate changes in abundance of proteins at $16 \mathrm{~h}$ time point due to secondary effects (such as transcriptional responses) of SHP2 degradation or inhibition. 
Figure S8. Selective SHP2 degradation by R1-5C in MOLT4 cells. MOLT4 cells were treated with $1 \mu \mathrm{M}$ R1-5C for $5 \mathrm{~h}$ and subjected to TMT-based proteomics. Scatterplot depicting relative fold-change in SHP2 abundance upon R1-5C treatment. SHP2/PTPN11 is highlighted in red.

Figure S9. SHP2 recovery after R1-5C washout. MV4;11 cells were treated with 100 nM R1$5 \mathrm{C}$ or DMSO carrier for $24 \mathrm{~h}$, followed by compound washout and incubation in media. Cells were harvested after $0.5,1,2,4,8$ or 24 h post-washout and SHP2 protein levels were assessed by immunoblotting.

Figure S10. R1-5C inhibits MAPK signaling. Downregulation of DUSP6 transcript levels in KYSE-520 cells after $2 \mathrm{~h}$ and $16 \mathrm{~h}$ treatment with $200 \mathrm{nM}$ R1-5C or DMSO carrier. DUSP6 mRNA was quantified by RT-qPCR using primer set $A$. 


\section{References}

1. Bentires-Alj M, Paez JG, David FS, et al. Activating mutations of the noonan syndrome-associated SHP2/PTPN11 gene in human solid tumors and adult acute myelogenous leukemia. Cancer Res. 2004;64(24):8816-8820.

2. Tartaglia M, Niemeyer CM, Fragale A, et al. Somatic mutations in PTPN11 in juvenile myelomonocytic leukemia, myelodysplastic syndromes and acute myeloid leukemia. Nat Genet. 2003;34(2):148-150.

3. Darian E, Guvench O, Yu B, Qu CK, MacKerell AD, Jr. Structural mechanism associated with domain opening in gain-of-function mutations in SHP2 phosphatase. Proteins. 2011;79(5):1573-1588.

4. Chen YN, LaMarche MJ, Chan HM, et al. Allosteric inhibition of SHP2 phosphatase inhibits cancers driven by receptor tyrosine kinases. Nature. 2016;535(7610):148-152.

5. Okazaki T, Maeda A, Nishimura H, Kurosaki T, Honjo T. PD-1 immunoreceptor inhibits B cell receptor-mediated signaling by recruiting src homology 2-domain-containing tyrosine phosphatase 2 to phosphotyrosine. Proc Natl Acad Sci U S A. 2001;98(24):13866-13871.

6. Zhao M, Guo $\mathrm{W}, \mathrm{Wu} \mathrm{Y}$, et al. SHP2 inhibition triggers anti-tumor immunity and synergizes with PD-1 blockade. Acta Pharm Sin B. 2019;9(2):304-315.

7. Liu C, Lu H, Wang H, et al. Combinations with Allosteric SHP2 Inhibitor TNO155 to Block Receptor Tyrosine Kinase Signaling. Clin Cancer Res. 2021;27(1):342-354.

8. LaRochelle JR, Fodor M, Xu X, et al. Structural and Functional Consequences of Three CancerAssociated Mutations of the Oncogenic Phosphatase SHP2. Biochemistry. 2016;55(15):2269-2277.

9. Tsutsumi R, Ran H, Neel BG. Off-target inhibition by active site-targeting SHP2 inhibitors. FEBS Open Bio. 2018;8(9):1405-1411.

10. Yuan X, Bu H, Zhou J, Yang CY, Zhang H. Recent Advances of SHP2 Inhibitors in Cancer Therapy: Current Development and Clinical Application. J Med Chem. 2020;63(20):11368-11396.

11. Garcia Fortanet J, Chen $\mathrm{CH}$, Chen YN, et al. Allosteric Inhibition of SHP2: Identification of a Potent, Selective, and Orally Efficacious Phosphatase Inhibitor. J Med Chem. 2016;59(17):7773-7782.

12. Nichols RJ, Haderk F, Stahlhut C, et al. RAS nucleotide cycling underlies the SHP2 phosphatase dependence of mutant BRAF-, NF1- and RAS-driven cancers. Nat Cell Biol. 2018;20(9):1064-1073.

13. Lu H, Liu C, Huynh H, et al. Resistance to allosteric SHP2 inhibition in FGFR-driven cancers through rapid feedback activation of FGFR. Oncotarget. 2020;11(3):265-281.

14. Aay N, Buckl A, Gill A, et al. 2,5-Disubstituted 3-Methyl Pyrazines and 2,5,6-Trisubstituted 3Methyl Pyrazines as Allosteric Shp2 Inhibitors: Revolution Medicines Inc; 2019.

15. Donovan KA, An J, Nowak RP, et al. Thalidomide promotes degradation of SALL4, a transcription factor implicated in Duane Radial Ray syndrome. Elife. 2018;7.

16. Kabsch W. Xds. Acta Crystallogr D Biol Crystallogr. 2010;66(Pt 2):125-132.

17. Emsley P, Cowtan K. Coot: model-building tools for molecular graphics. Acta Crystallogr D Biol Crystallogr. 2004;60(Pt 12 Pt 1):2126-2132.

18. Afonine PV, Grosse-Kunstleve RW, Echols N, et al. Towards automated crystallographic structure refinement with phenix.refine. Acta Crystallogr D Biol Crystallogr. 2012;68(Pt 4):352-367.

19. Moriarty NW, Grosse-Kunstleve RW, Adams PD. electronic Ligand Builder and Optimization Workbench (eLBOW): a tool for ligand coordinate and restraint generation. Acta Crystallogr D Biol Crystallogr. 2009;65(Pt 10):1074-1080.

20. Chen VB, Arendall WB, 3rd, Headd JJ, et al. MolProbity: all-atom structure validation for macromolecular crystallography. Acta Crystallogr D Biol Crystallogr. 2010;66(Pt 1):12-21.

21. Morin A, Eisenbraun B, Key J, et al. Collaboration gets the most out of software. Elife. 2013;2:e01456. 
22. Lin KM, Lin SJ, Lin JH, et al. Dysregulation of Dual-Specificity Phosphatases by Epstein-Barr Virus LMP1 and Its Impact on Lymphoblastoid Cell Line Survival. J Virol. 2020;94(4).

23. Winter GE, Buckley DL, Paulk J, et al. DRUG DEVELOPMENT. Phthalimide conjugation as a strategy for in vivo target protein degradation. Science. 2015;348(6241):1376-1381.

24. Vannam R, Sayilgan J, Ojeda S, et al. Targeted degradation of the enhancer lysine acetyltransferases CBP and p300. Cell Chem Biol. 2021.

25. Wang $L$, Shao $X$, Zhong $T$, et al. Discovery of a first-in-class CDK2 selective degrader for AML differentiation therapy. Nat Chem Biol. 2021.

26. Zhang F, Wu Z, Chen P, et al. Discovery of a new class of PROTAC BRD4 degraders based on a dihydroquinazolinone derivative and lenalidomide/pomalidomide. Bioorg Med Chem.

2020;28(1):115228.

27. Shahbazi S, Peer CJ, Polizzotto MN, et al. A sensitive and robust HPLC assay with fluorescence detection for the quantification of pomalidomide in human plasma for pharmacokinetic analyses. $J$ Pharm Biomed Anal. 2014;92:63-68.

28. LaRochelle JR, Fodor M, Vemulapalli V, et al. Structural reorganization of SHP2 by oncogenic mutations and implications for oncoprotein resistance to allosteric inhibition. Nat Commun. 2018;9(1):4508.

29. Zhang D, Baek SH, Ho A, Kim K. Degradation of target protein in living cells by small-molecule proteolysis inducer. Bioorg Med Chem Lett. 2004;14(3):645-648.

30. Zorba A, Nguyen $\mathrm{C}, \mathrm{Xu} \mathrm{Y}$, et al. Delineating the role of cooperativity in the design of potent PROTACs for BTK. Proc Natl Acad Sci U S A. 2018;115(31):E7285-E7292.

31. Wang B, Wu S, Liu J, Yang K, Xie H, Tang W. Development of selective small molecule MDM2 degraders based on nutlin. Eur J Med Chem. 2019;176:476-491.

32. Li Y, Yang J, Aguilar A, et al. Discovery of MD-224 as a First-in-Class, Highly Potent, and Efficacious Proteolysis Targeting Chimera Murine Double Minute 2 Degrader Capable of Achieving Complete and Durable Tumor Regression. J Med Chem. 2019;62(2):448-466.

33. Wang M, Lu J, Wang M, Yang CY, Wang S. Discovery of SHP2-D26 as a First, Potent, and Effective PROTAC Degrader of SHP2 Protein. J Med Chem. 2020;63(14):7510-7528.

34. Yang $X$, Wang Z, Pei $Y$, et al. Discovery of thalidomide-based PROTAC small molecules as the highly efficient SHP2 degraders. Eur J Med Chem. 2021;218:113341. 
bioRxiv preprint doi: https://doi.org/10.1101/2021.06.02.446786; this version posted June 2, 2021. The copyright holder for this preprint (which

was not certified by peer review) is the author/funder, who has granted bioRxiv a license to display the preprint in perpetuity. It is made available under aCC-BY-NC 4.0 International license.

A

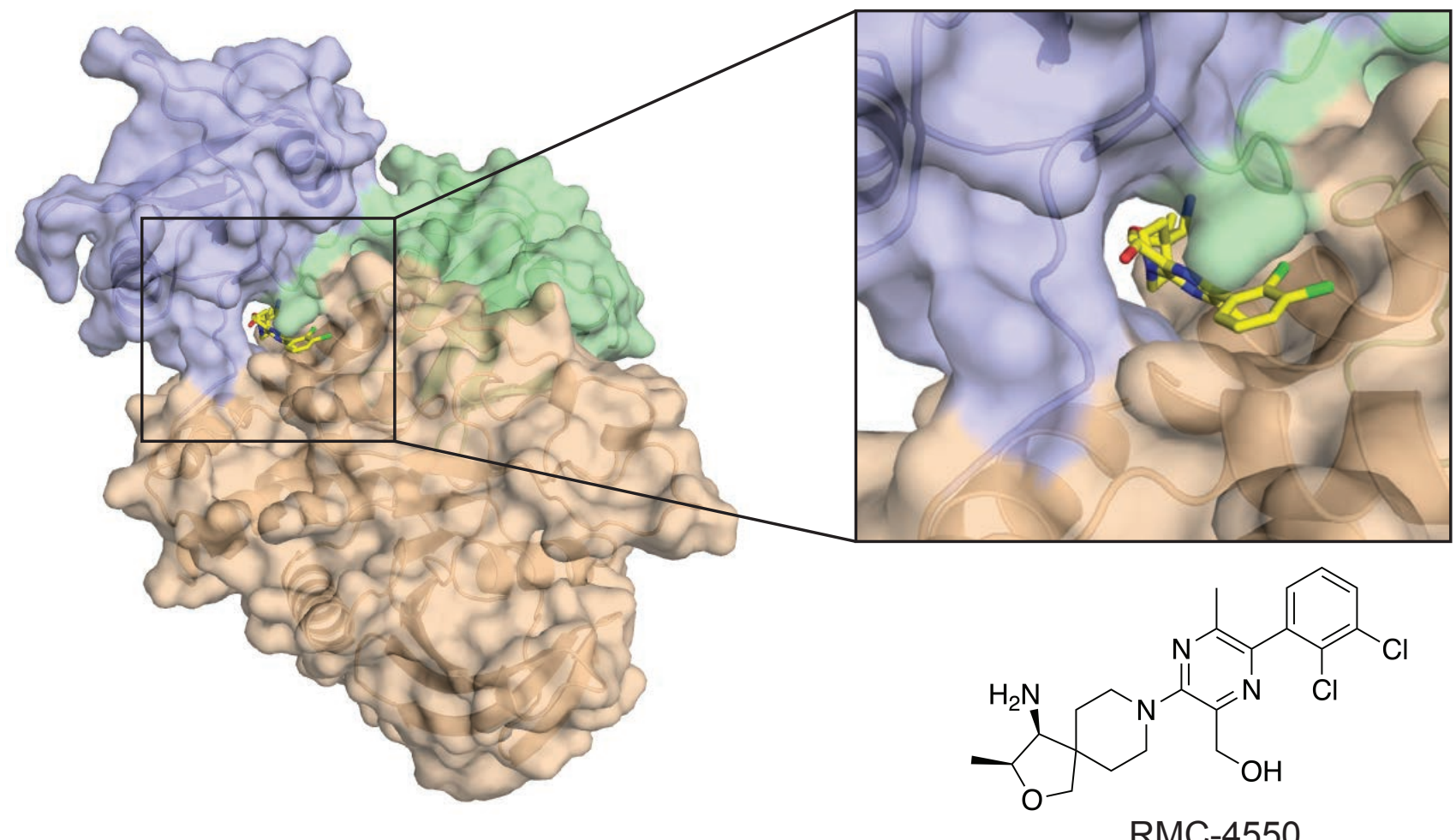

B

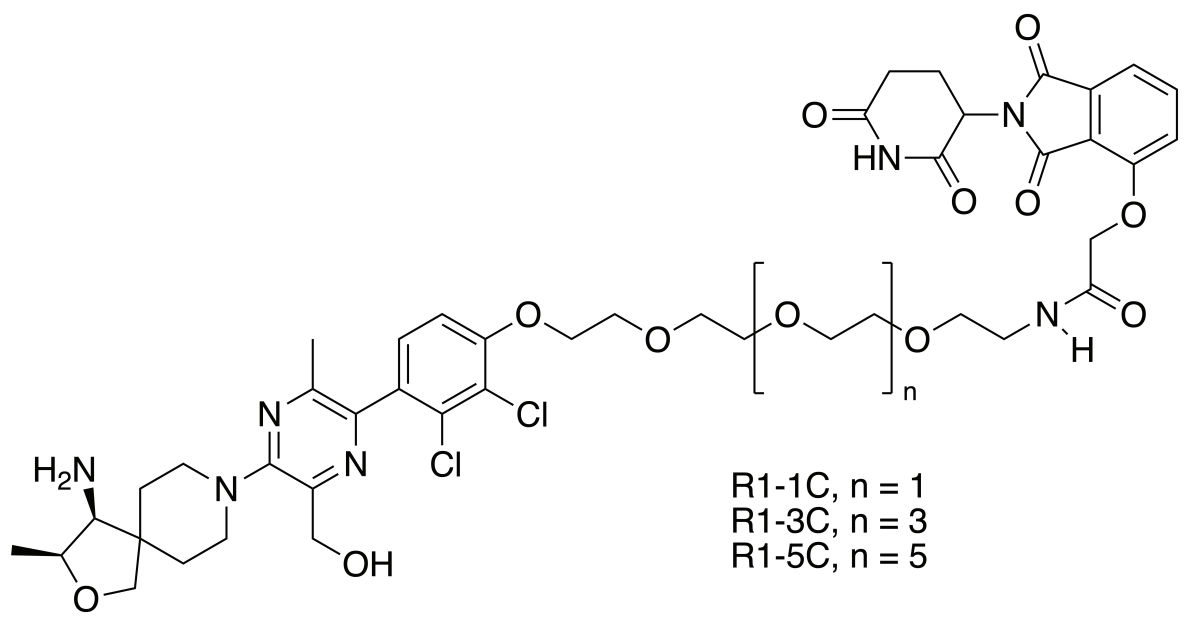


bioRxiv preprint doi: https://doi.org/10.1101/2021.06.02.446786; this version posted June 2, 2021. The copyright holder for this preprint (which was not certified by peer review) is the author/funder, who has granted bioRxiv a license to display the preprint in perpetuity. It is made available under aCC-BY-NC 4.0 International license.

A

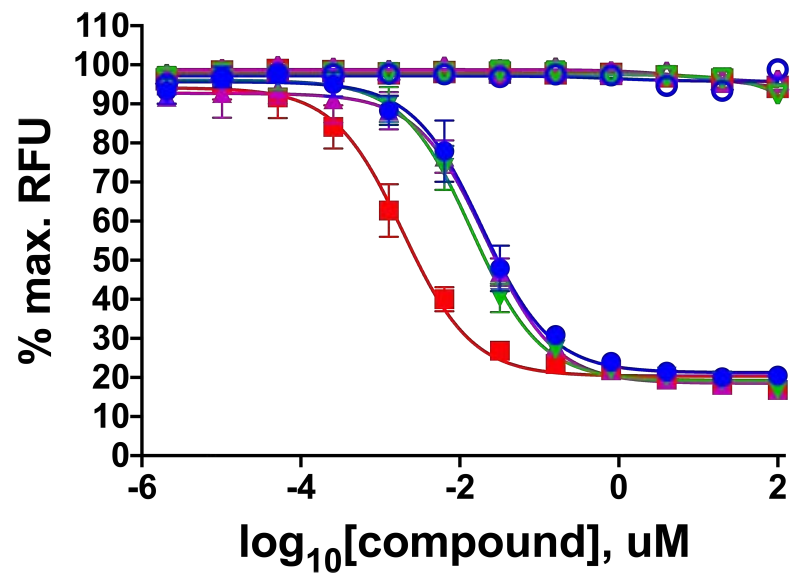

- R1-1C + SHP2-F285S $\left(\mathrm{IC}_{50}=18.9 \mathrm{nM}\right)$

$\theta \mathrm{R} 1-1 \mathrm{C}+\mathrm{PTP}$

F $1-3 \mathrm{C}+\mathrm{SHP} 2-\mathrm{F} 285 \mathrm{~S}\left(\mathrm{IC}_{50}=14.1 \mathrm{nM}\right)$

$\forall \mathrm{R} 1-3 \mathrm{C}+\mathrm{PTP}$

$\star \mathrm{R} 1-5 \mathrm{C}+\mathrm{SHP} 2-\mathrm{F} 285 \mathrm{~S}\left(\mathrm{IC}_{50}=22.5 \mathrm{nM}\right)$

$\triangle \mathrm{R} 1-5 \mathrm{C}+\mathrm{PTP}$

RMC-4550 + SHP2-F285S $\left(\mathrm{IC}_{50}=1.5 \mathrm{nM}\right)$

ㅂ RMC-4550 + PTP

B

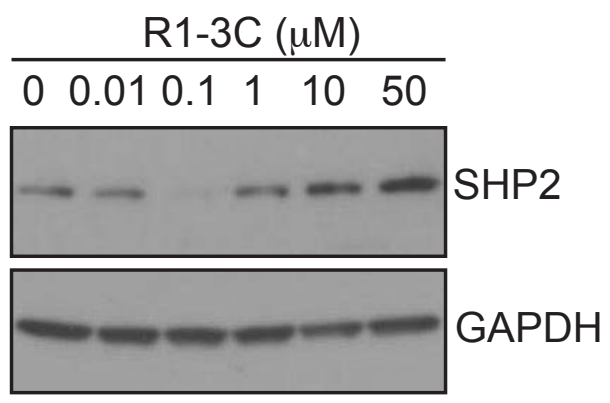

C
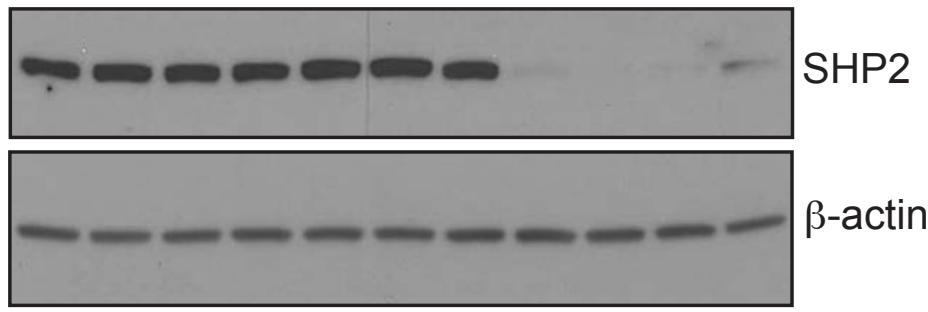

Figure 2 
bioRxiv preprint doi: https://doi.org/10.1101/2021.06.02.446786; this version posted June 2, 2021. The copyright holder for this preprint (which was not certified by peer review) is the author/funder, who has granted bioRxiv a license to display the preprint in perpetuity. It is made available under aCC-BY-NC 4.0 International license.

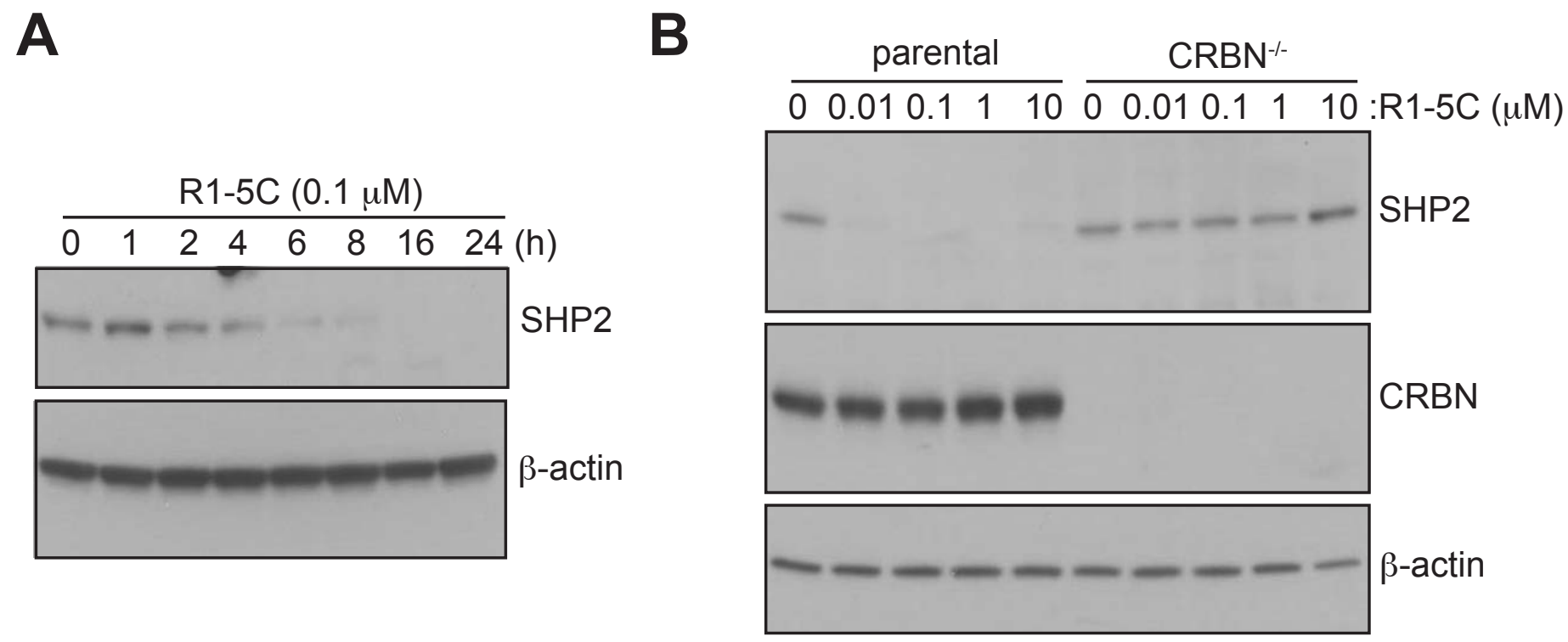

Figure 3 
bioRxiv preprint doi: https://doi.org/10.1101/2021.06.02.446786; this version posted June 2, 2021. The copyright holder for this preprint (which was not certified by peer review) is the author/funder, who has granted bioRxiv a license to display the preprint in perpetuity. It is made

A

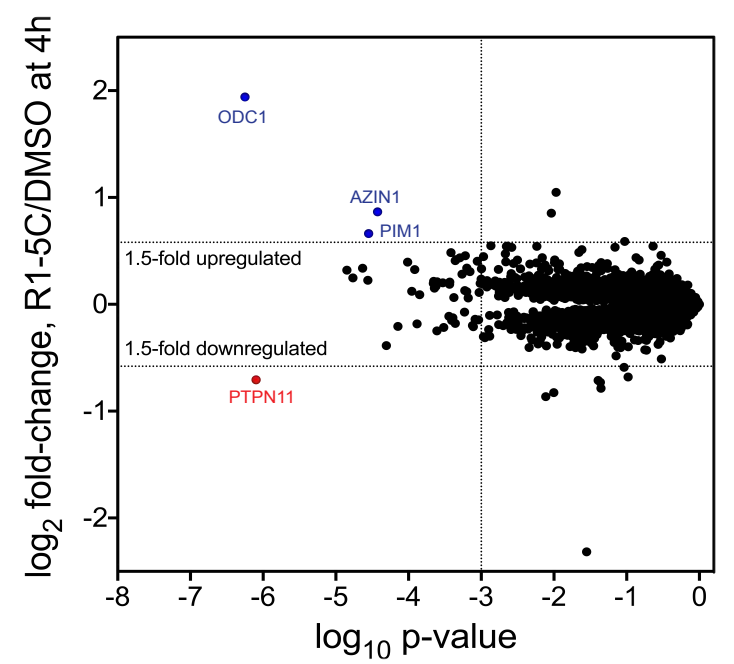

C

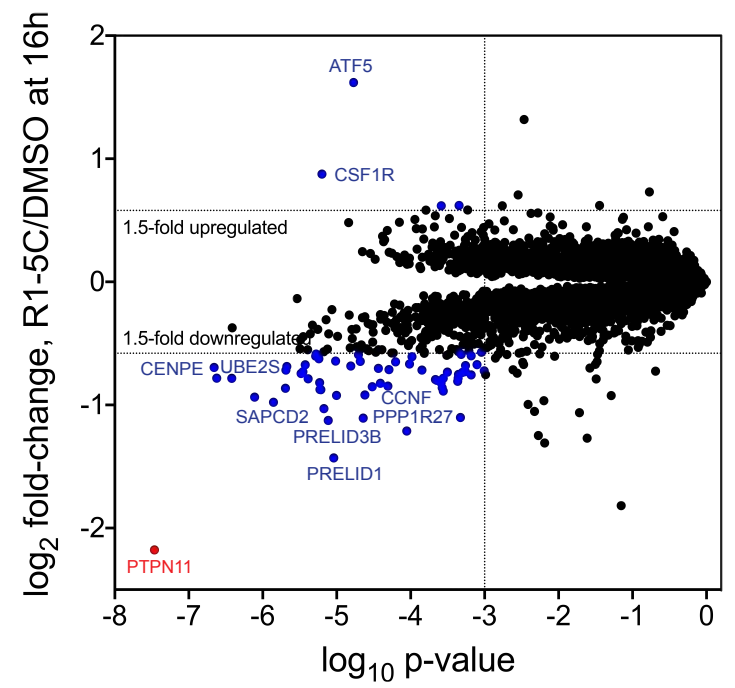

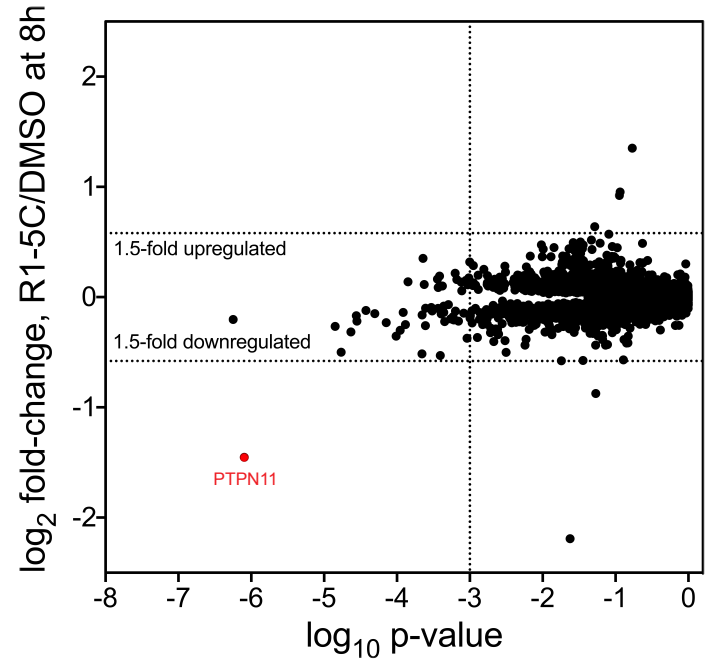

D

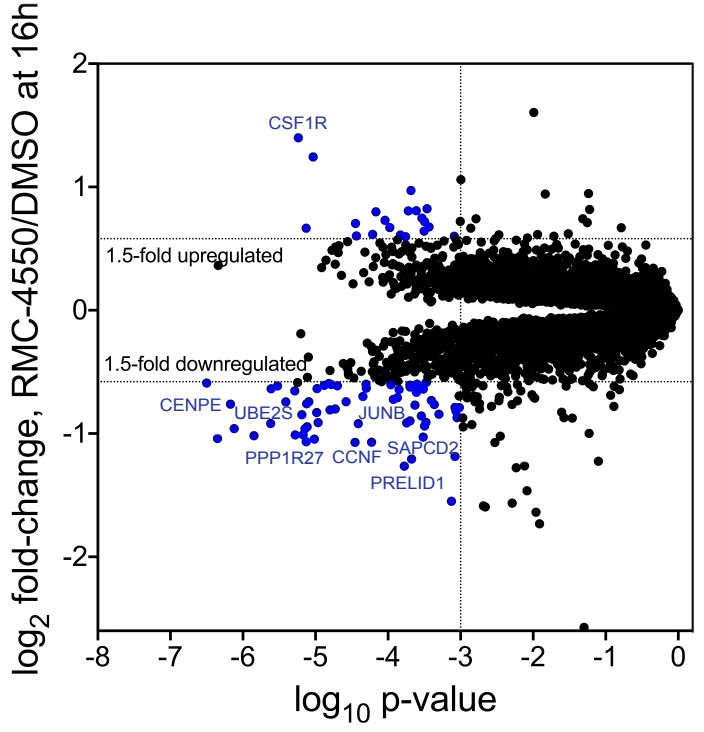

E

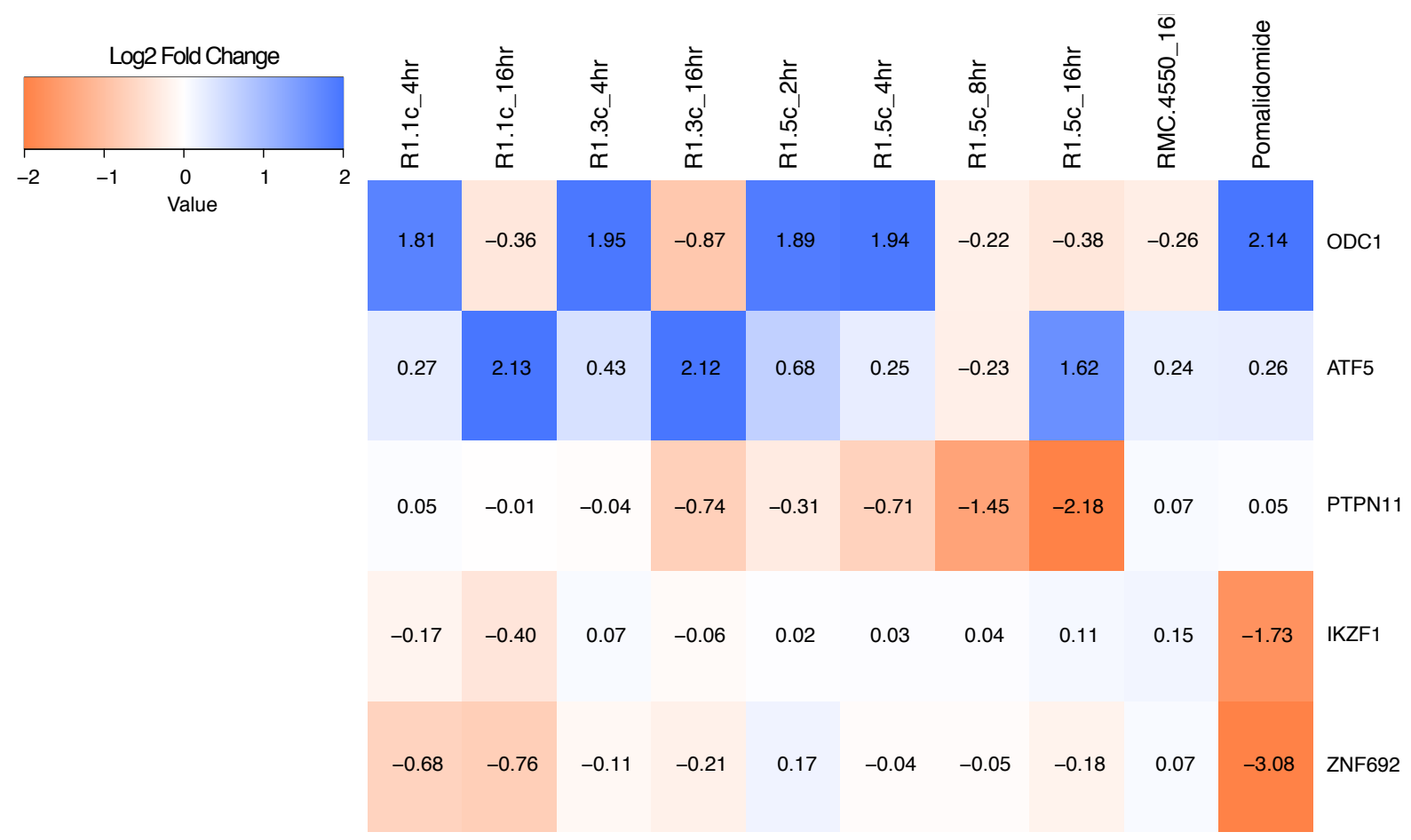

Figure 4 
bioRxiv preprint doi: https://doi.org/10.1101/2021.06.02.446786; this version posted June 2, 2021. The copyright holder for this preprint (which was not certified by peer review) is the author/funder, who has granted bioRxiv a license to display the preprint in perpetuity. It is made

A available under aCC-BY-NC 4.0 International license.

\section{DUSP6}

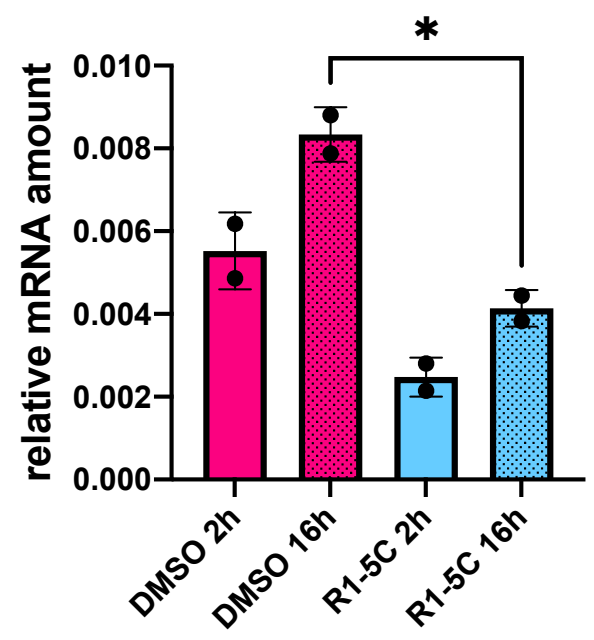

B

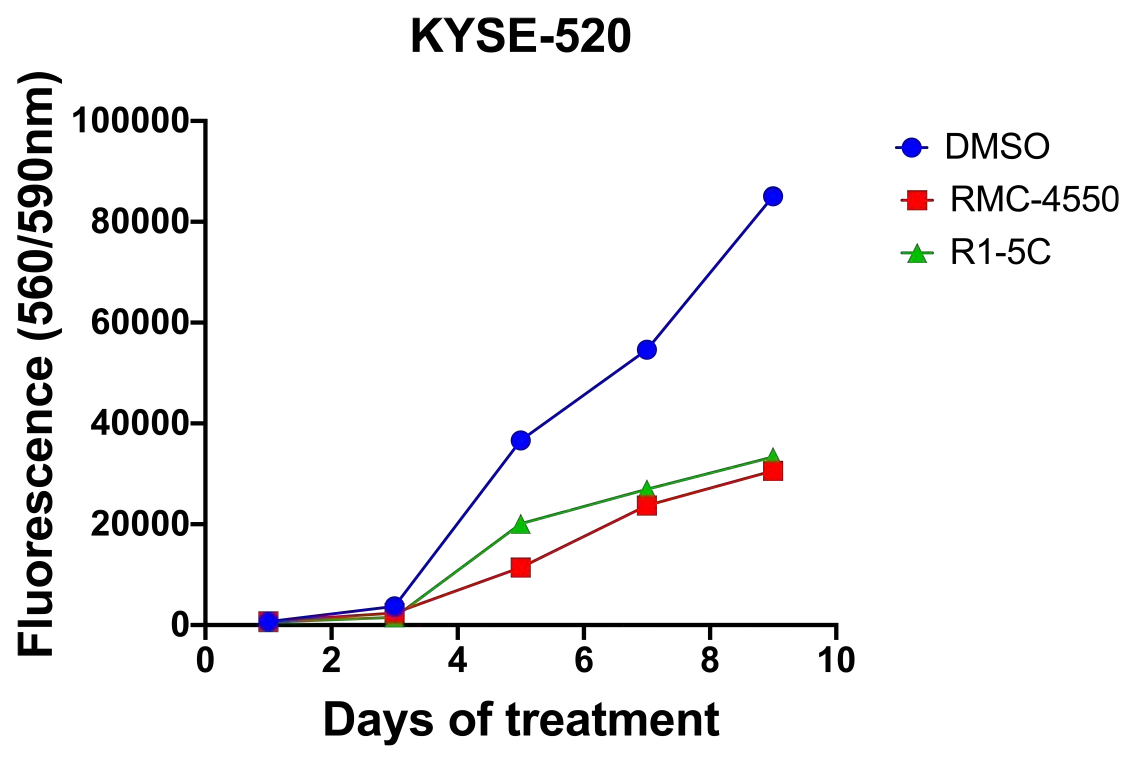

MV4;11

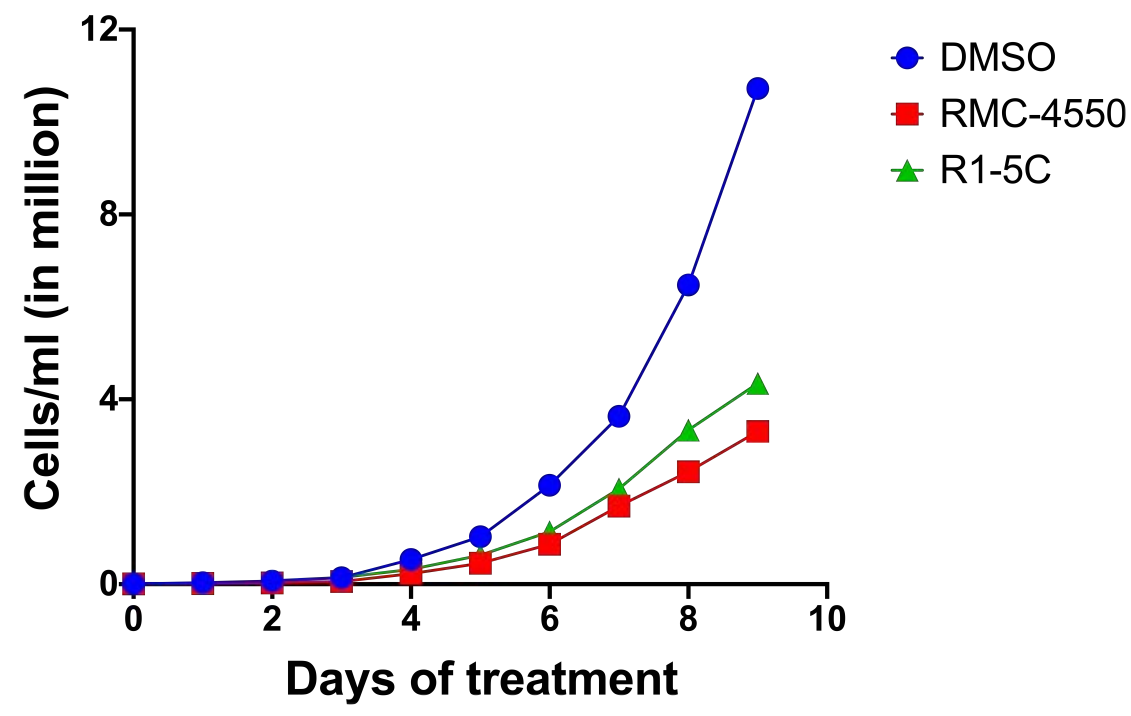

Figure 5 
bioRxiv preprint doi: https://doi.org/10.1101/2021.06.02.446786; this version posted June 2, 2021. The copyright holder for this preprint (which

was not certified by peer review) is the author/funder, who has granted bioRxiv a license to display the preprint in perpetuity. It is made

A

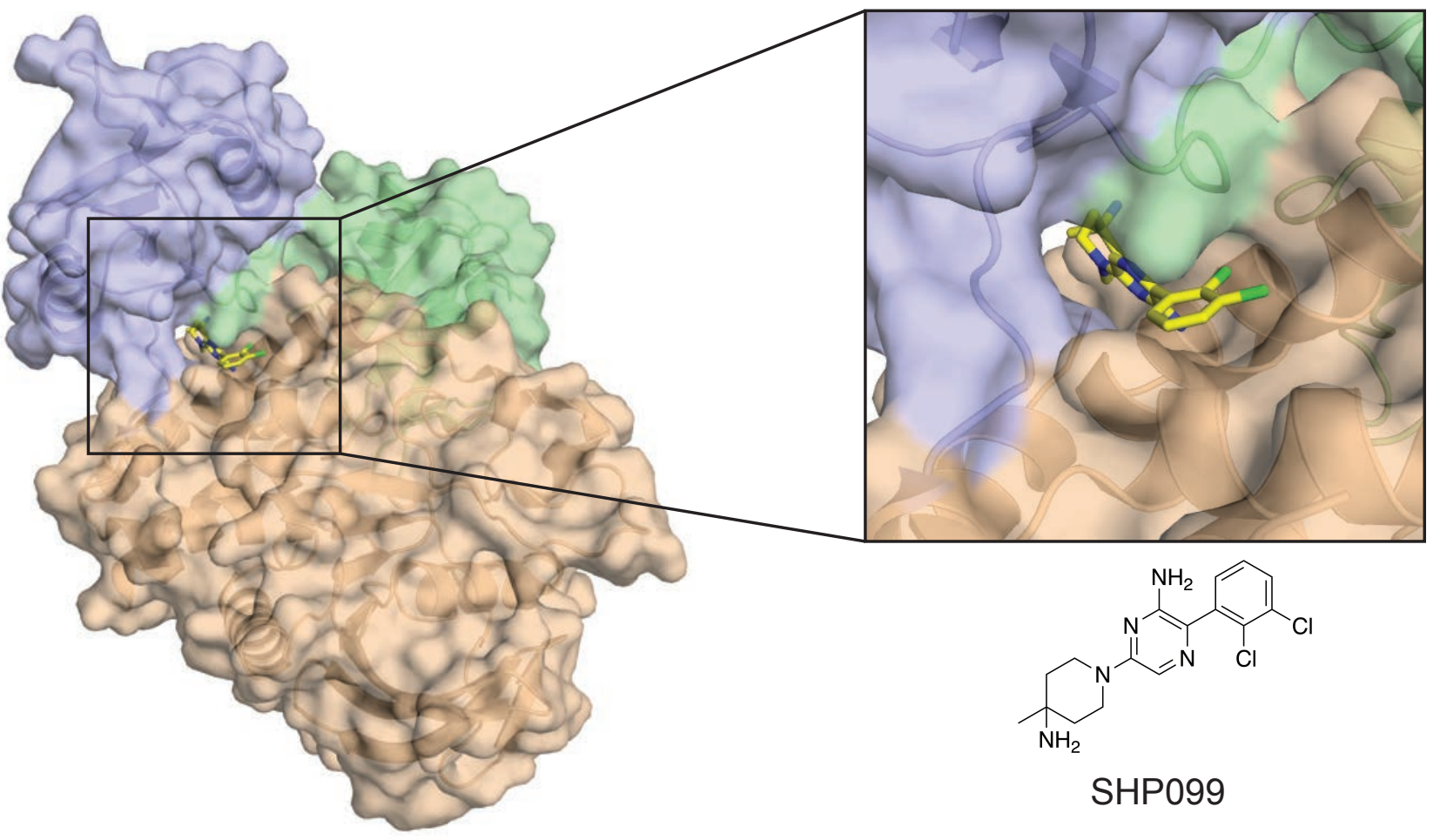<smiles>CC(C)(C)OCCOCCOCCOCCOCCOCCNC(=O)COc1cccc2[nH]c(=O)n(C3CCC(=O)NC3=O)c(=O)c12</smiles><smiles>CC1(N)CCN(c2cnc(-c3cc(CCOCCOCCOCCOCCOCCNC(=O)COc4cccc5c4C(=O)N(C4CCC(=O)NC4=O)C5=O)cc(Cl)c3Cl)c(N)n2)CC1</smiles>

S9-2C

D

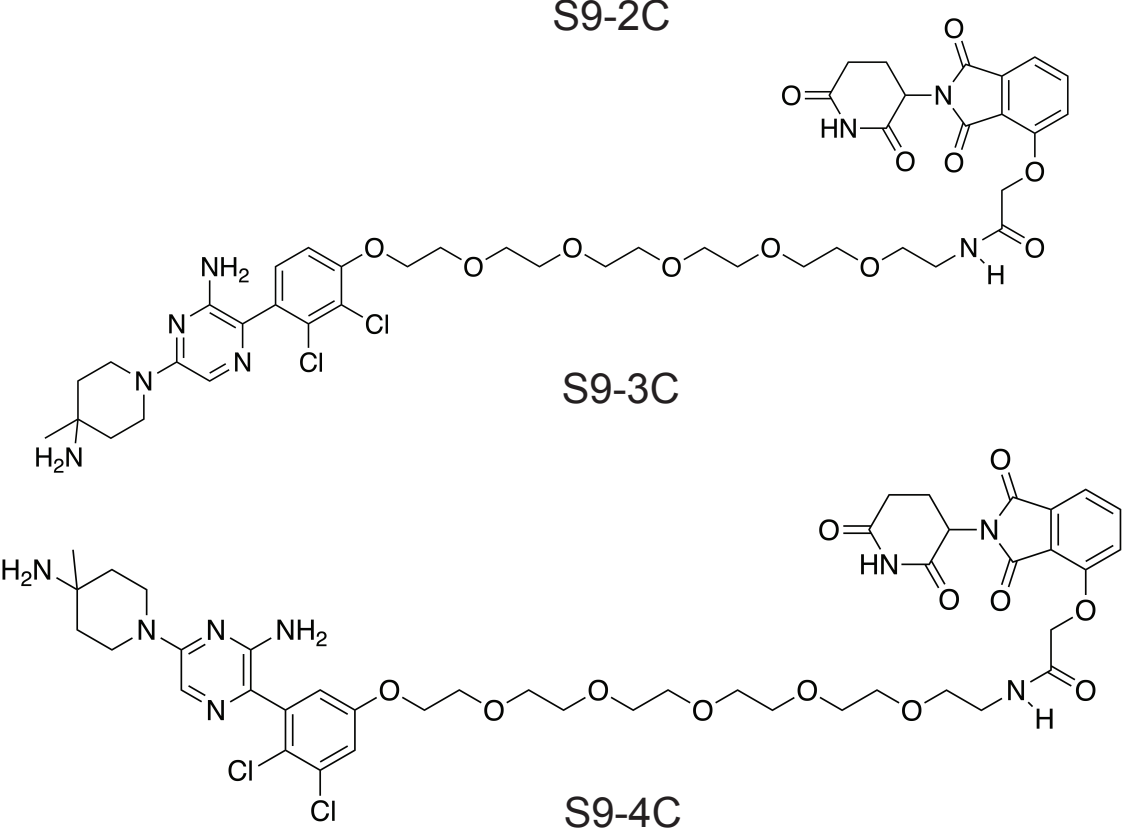


A
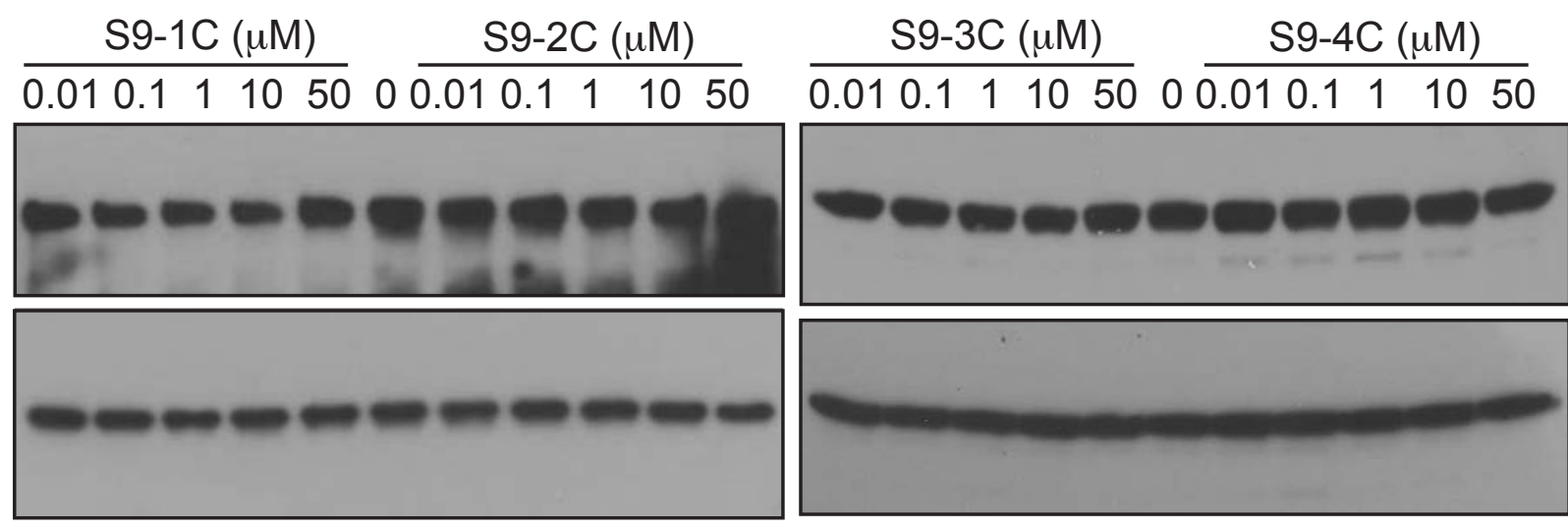

SHP2

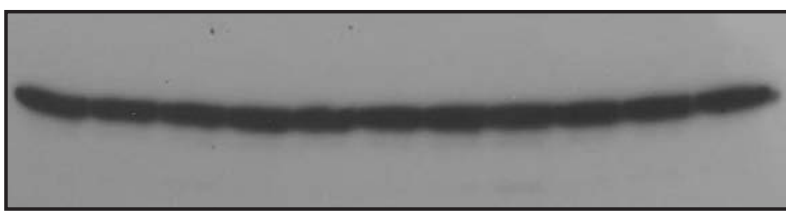

$\beta$-actin

B

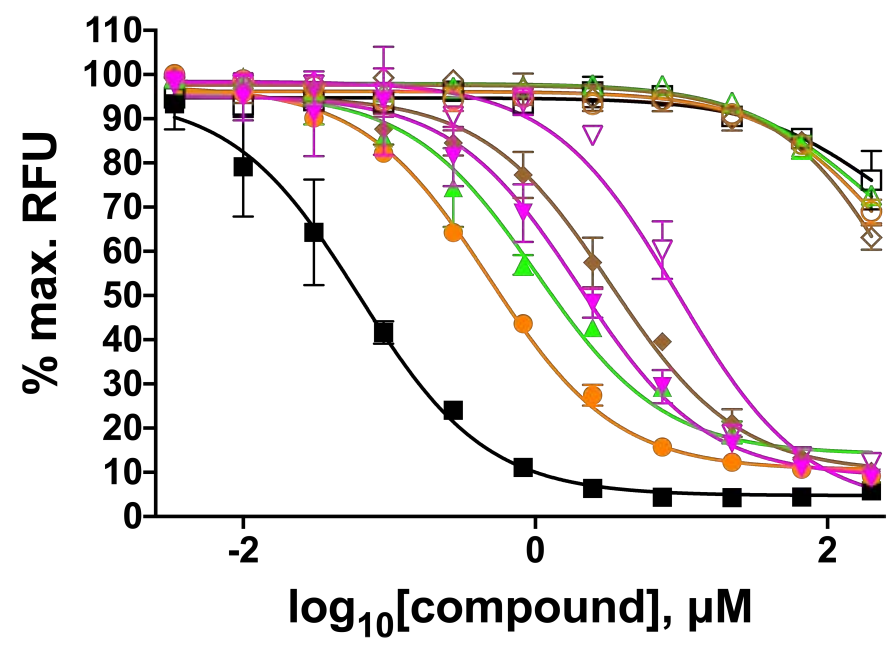

$$
\begin{aligned}
& \text { * S9-1C + SHP2-F285S }\left(\mathrm{IC}_{50}=2.137 \mu \mathrm{M}\right) \\
& \forall \text { S9-1C + PTP } \\
& \text { - S9-2C + SHP2-F285S }\left(\mathrm{IC}_{50}=3.774 \mu \mathrm{M}\right) \\
& \Leftrightarrow \mathrm{S} 9-2 \mathrm{C}+\mathrm{PTP} \\
& \text { - S9-3C + SHP2-F285S }\left(\mathrm{IC}_{50}=0.481 \mu \mathrm{M}\right) \\
& \ominus \text { S9-3C + PTP } \\
& \star \text { S9-4C + SHP2-F285S }\left(\mathrm{IC}_{50}=1.662 \mu \mathrm{M}\right) \\
& \triangle \mathrm{S} 9-4 \mathrm{C}+\mathrm{PTP} \\
& \text { - SHP099 + SHP2-F285S }\left(\mathrm{IC}_{50}=0.062 \mu \mathrm{M}\right) \\
& \boxminus \text { SHP099 + PTP }
\end{aligned}
$$


<smiles>CC1(N)CCN(c2cnc(-c3cccc(Cl)c3Cl)c(N)n2)CC1</smiles>

SHP099<smiles>CC1(N)CCN(c2cnc(-c3ccc(OCCOCCOCCOCCOCCOCCN)c(Cl)c3Cl)c(N)n2)CC1</smiles>

SHP099-I34

B

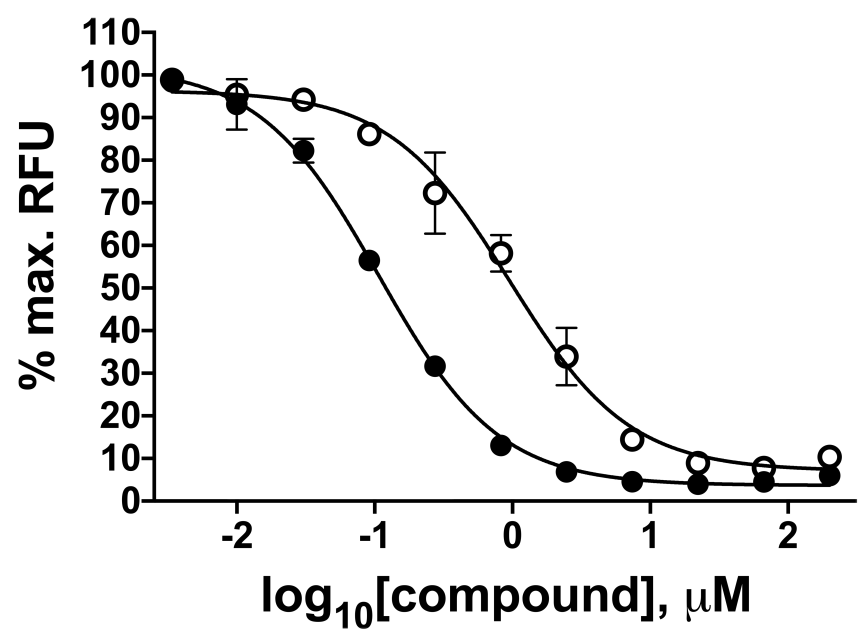

SHP099 + SHP2-F285S $\left(\mathrm{IC}_{50}=0.062 \mu \mathrm{M}\right)$

$\theta$ SHP099-I34 + SHP2-F285S $\left(\mathrm{IC}_{50}=0.58 \mu \mathrm{M}\right)$

C

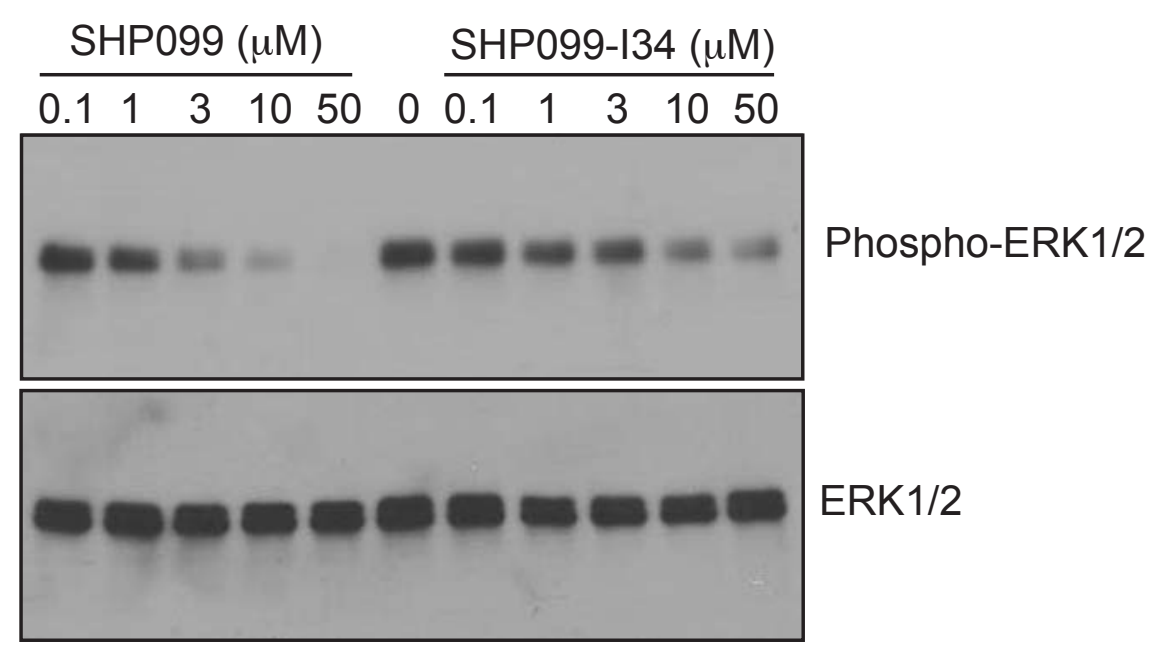

Figure S3 
bioRxiv preprint doi: https://doi.org/10.1101/2021.06.02.446786; this version posted June 2, 2021. The copyright holder for this preprint (which was not certified by peer review) is the author/funder, who has granted bioRxiv a license to display the preprint in perpetuity. It is made available under aCC-BY-NC 4.0 International license.

\section{A}

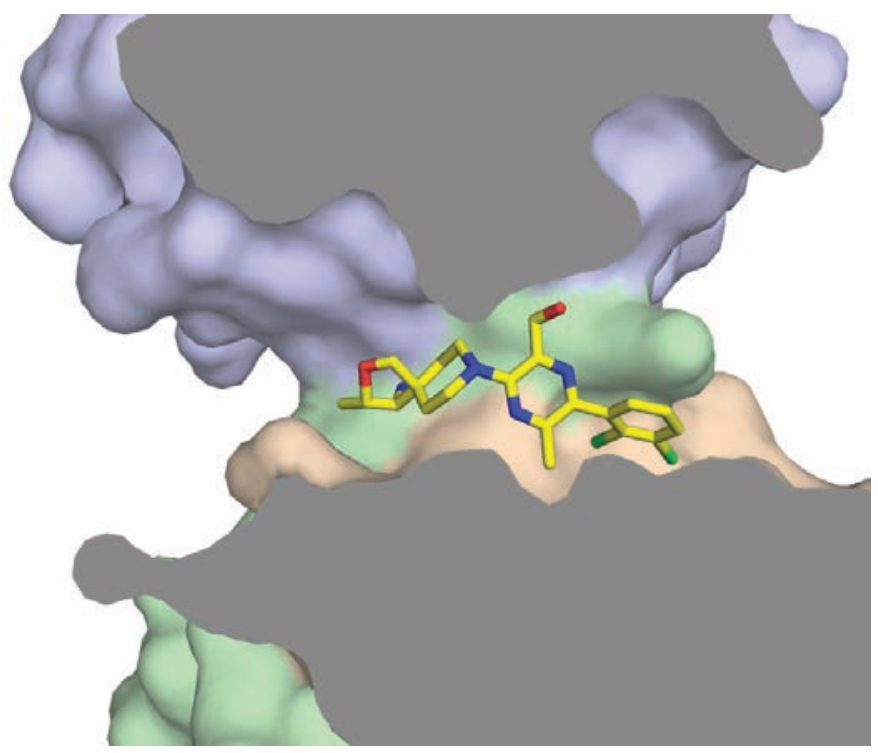

B

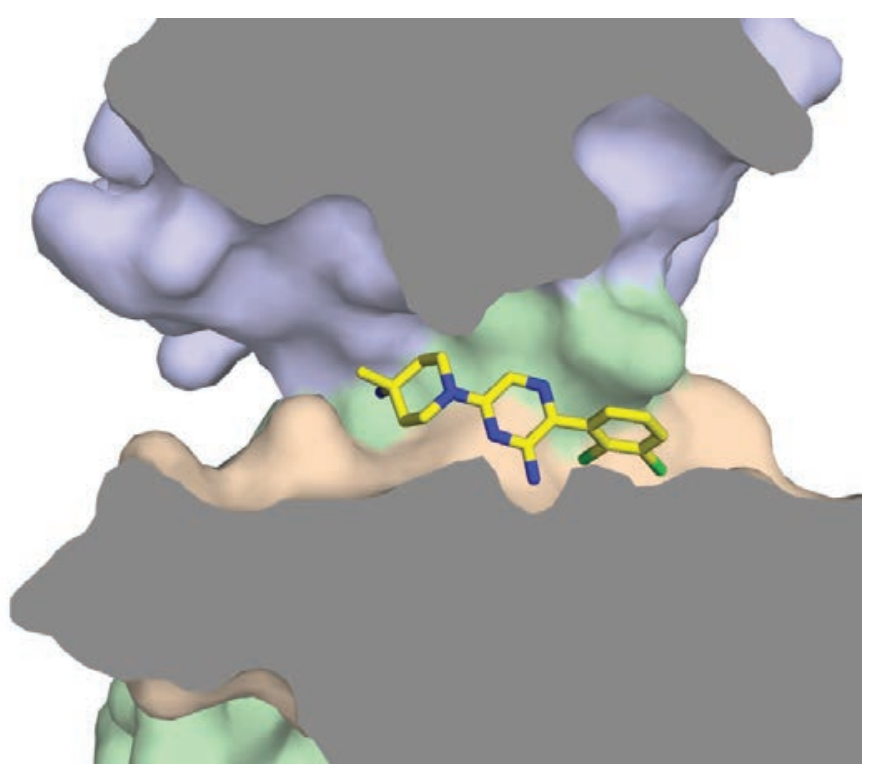


A

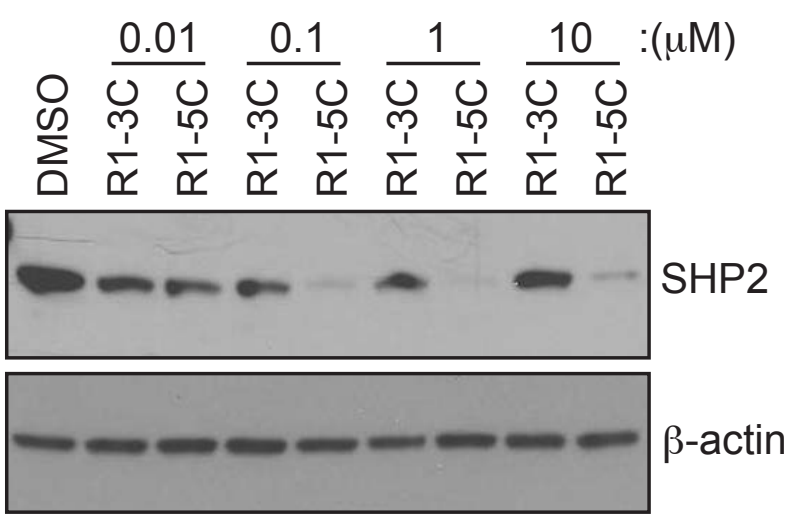

B

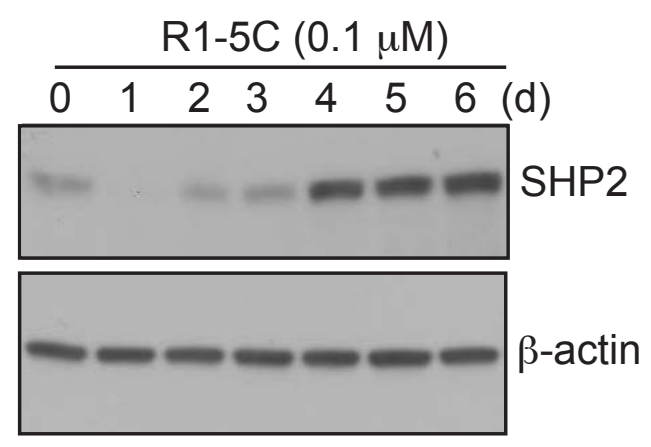

C

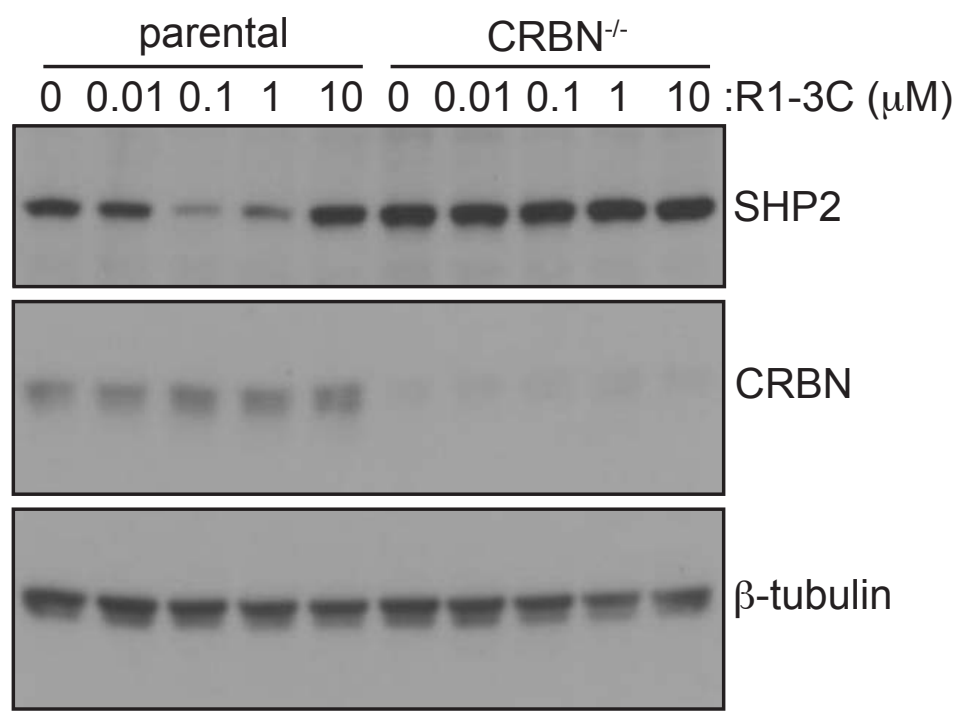

Figure S5 


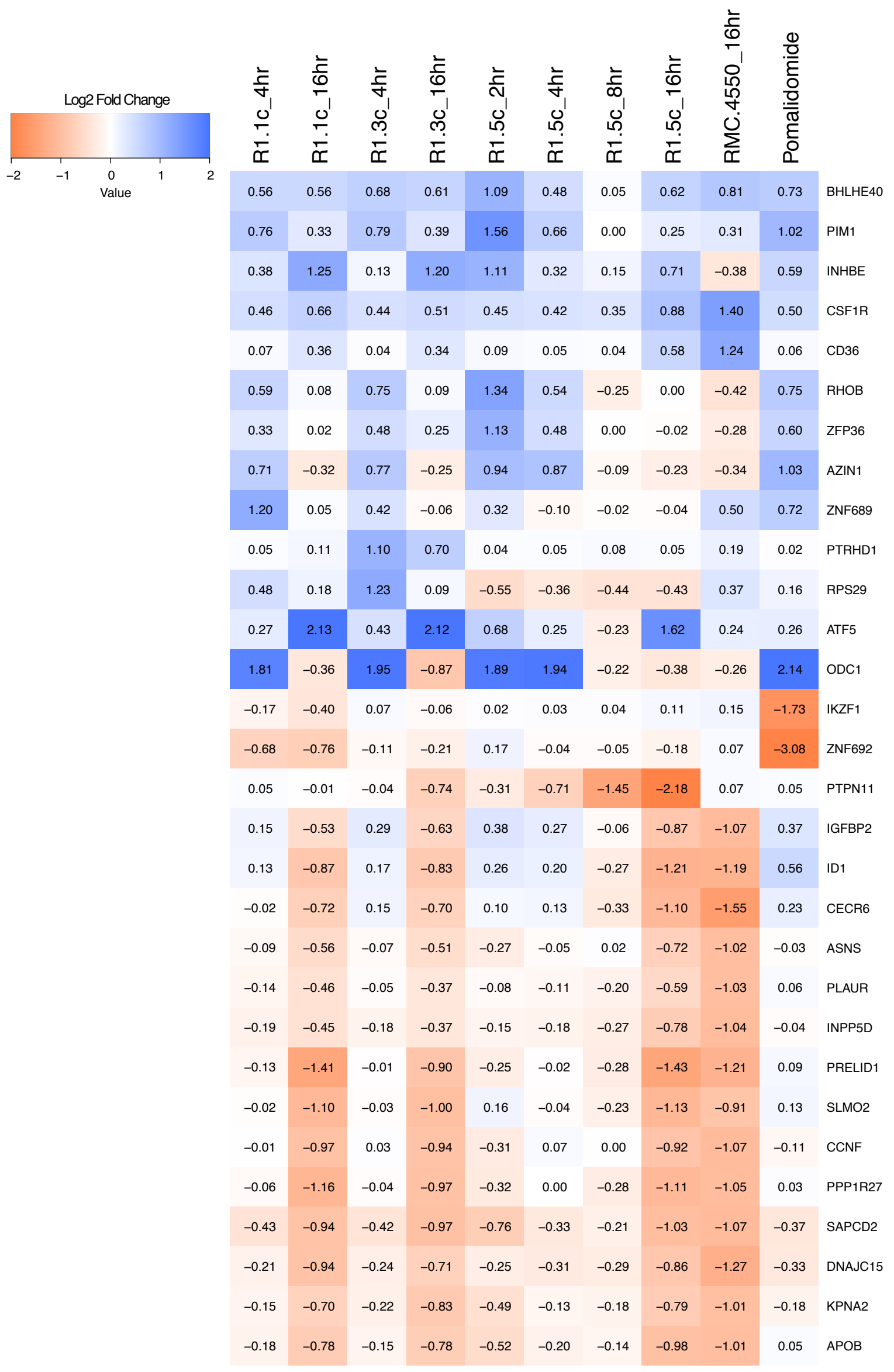


bioRxiv preprint doi: https://doi.org/10.1101/2021.06.02.446786; this version posted June 2, 2021. The copyright holder for this preprint (which was not certified by peer review) is the author/funder, who has granted bioRxiv a license to display the preprint in perpetuity. It is made

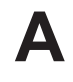
available under aCC-BY-NC 4.0 International license.

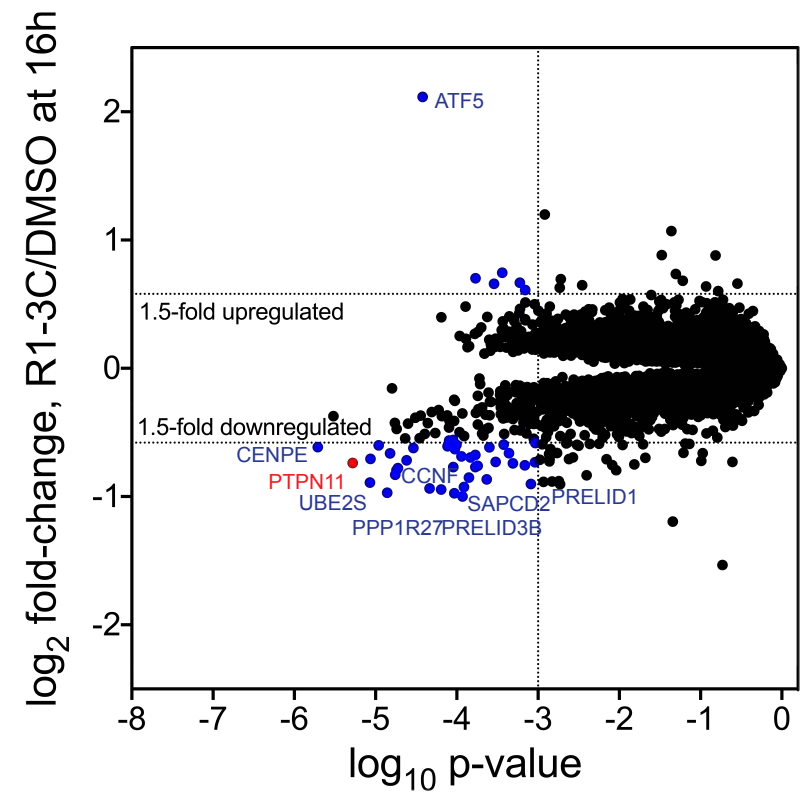

B
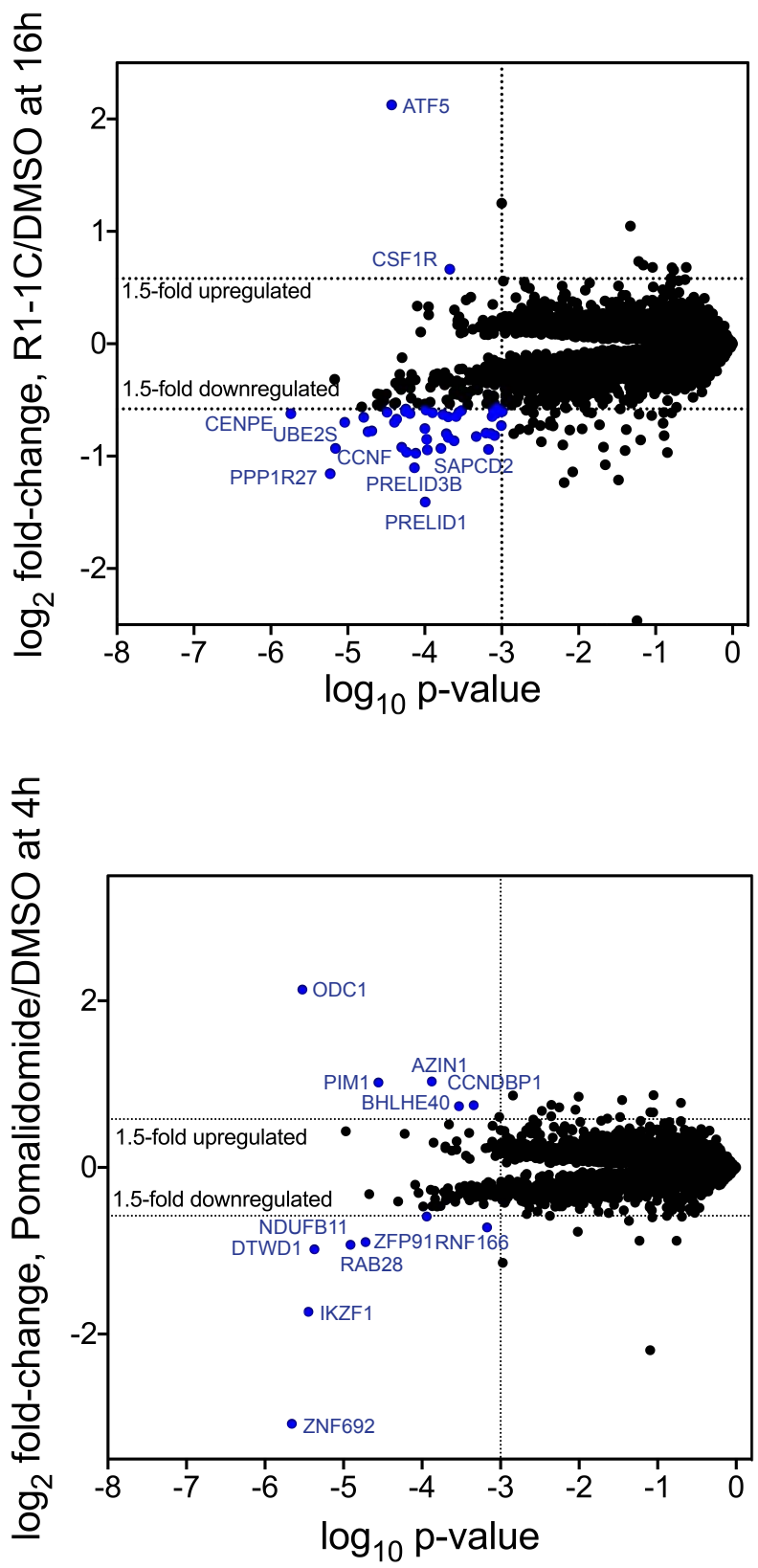

Figure S7 
bioRxiv preprint doi: https://doi.org/10.1101/2021.06.02.446786; this version posted June 2, 2021. The copyright holder for this preprint (which was not certified by peer review) is the author/funder, who has granted bioRxiv a license to display the preprint in perpetuity. It is made available under aCC-BY-NC 4.0 International license.

\section{MOLT4}

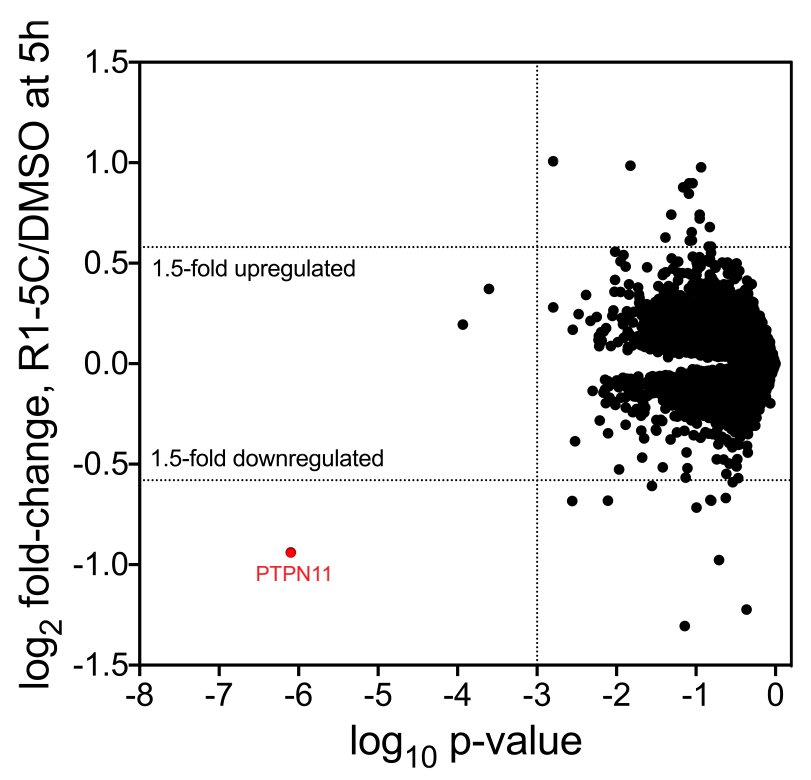

Figure $\mathrm{S} 8$ 
bioRxiv preprint doi: https://doi.org/10.1101/2021.06.02.446786; this version posted June 2, 2021. The copyright holder for this preprint (which was not certified by peer review) is the author/funder, who has granted bioRxiv a license to display the preprint in perpetuity. It is made available under aCC-BY-NC 4.0 International license.
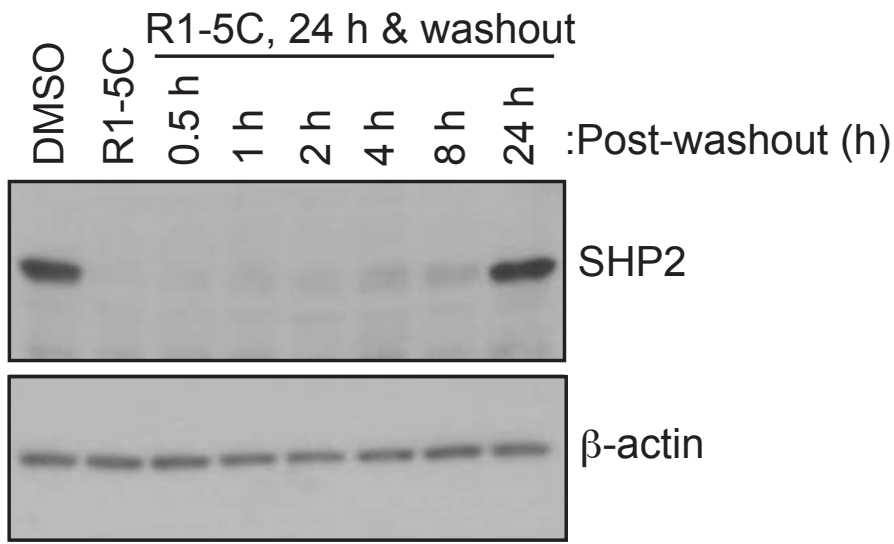
bioRxiv preprint doi: https://doi.org/10.1101/2021.06.02.446786; this version posted June 2, 2021. The copyright holder for this preprint (which was not certified by peer review) is the author/funder, who has granted bioRxiv a license to display the preprint in perpetuity. It is made available under aCC-BY-NC 4.0 International license.

\section{DUSP6}

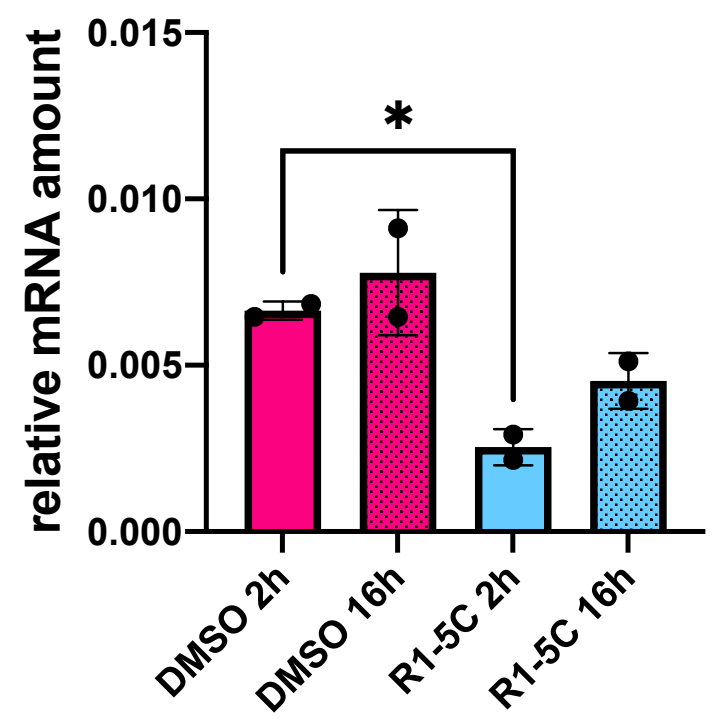


Table S1: X-ray crystallography data collection and refinement statistics.

\begin{tabular}{|c|c|}
\hline Wavelength $(\lambda, \AA)$ & 0.97918 \\
\hline Resolution range $(\AA)$ & $43.76-1.80(1.86-1.80)$ \\
\hline Space group & $\mathrm{P} 1211$ \\
\hline Unit cell (Å, degrees) & $45.79,213.78,55.85,90,96.83,90$ \\
\hline Total reflections & $285234(27302)$ \\
\hline Unique reflections & $96389(9595)$ \\
\hline Multiplicity & $3.0(2.8)$ \\
\hline Completeness (\%) & $98.29(97.68)$ \\
\hline Mean $I / \sigma(I)$ & $10.87(0.90)$ \\
\hline Wilson B-factor & 30.73 \\
\hline R-merge & $0.05882(1.058)$ \\
\hline R-meas & $0.0715(1.303)$ \\
\hline R-pim & $0.04012(0.7502)$ \\
\hline $\mathrm{CC}_{1 / 2}$ & $0.999(0.422)$ \\
\hline $\mathrm{CC}^{*}$ & $1(0.771)$ \\
\hline Reflections used in refinement & $96340(9572)$ \\
\hline Reflections used for R-free & $1997(199)$ \\
\hline R-work & $0.1861(0.3863)$ \\
\hline R-free & $0.2253(0.4063)$ \\
\hline CC(work) & $0.969(0.688)$ \\
\hline $\mathrm{CC}$ (free) & $0.954(0.652)$ \\
\hline Number of non-hydrogen atoms & 8811 \\
\hline Macromolecules & 8058 \\
\hline Ligands & 60 \\
\hline Solvent & 693 \\
\hline Protein residues & 992 \\
\hline RMS(bonds, Å) & 0.005 \\
\hline RMS(angles, degrees) & 0.71 \\
\hline Ramachandran favored (\%) & 97.52 \\
\hline Ramachandran allowed (\%) & 2.07 \\
\hline Ramachandran outliers (\%) & 0.41 \\
\hline Rotamer outliers (\%) & 0.56 \\
\hline Clashscore & 3.86 \\
\hline Average B-factor $\left(\AA^{2}\right)$ & 41.01 \\
\hline Macromolecules & 40.7 \\
\hline Ligands & 33.56 \\
\hline Solvent & 45.19 \\
\hline
\end{tabular}


bioRxiv preprint doi: https://doi.org/10.1101/2021.06.02.446786; this version posted June 2, 2021. The copyright holder for this preprint (which was not certified by peer review) is the author/funder, who has granted bioRxiv a license to display the preprint in perpetuity. It is made available under aCC-BY-NC 4.0 International license.

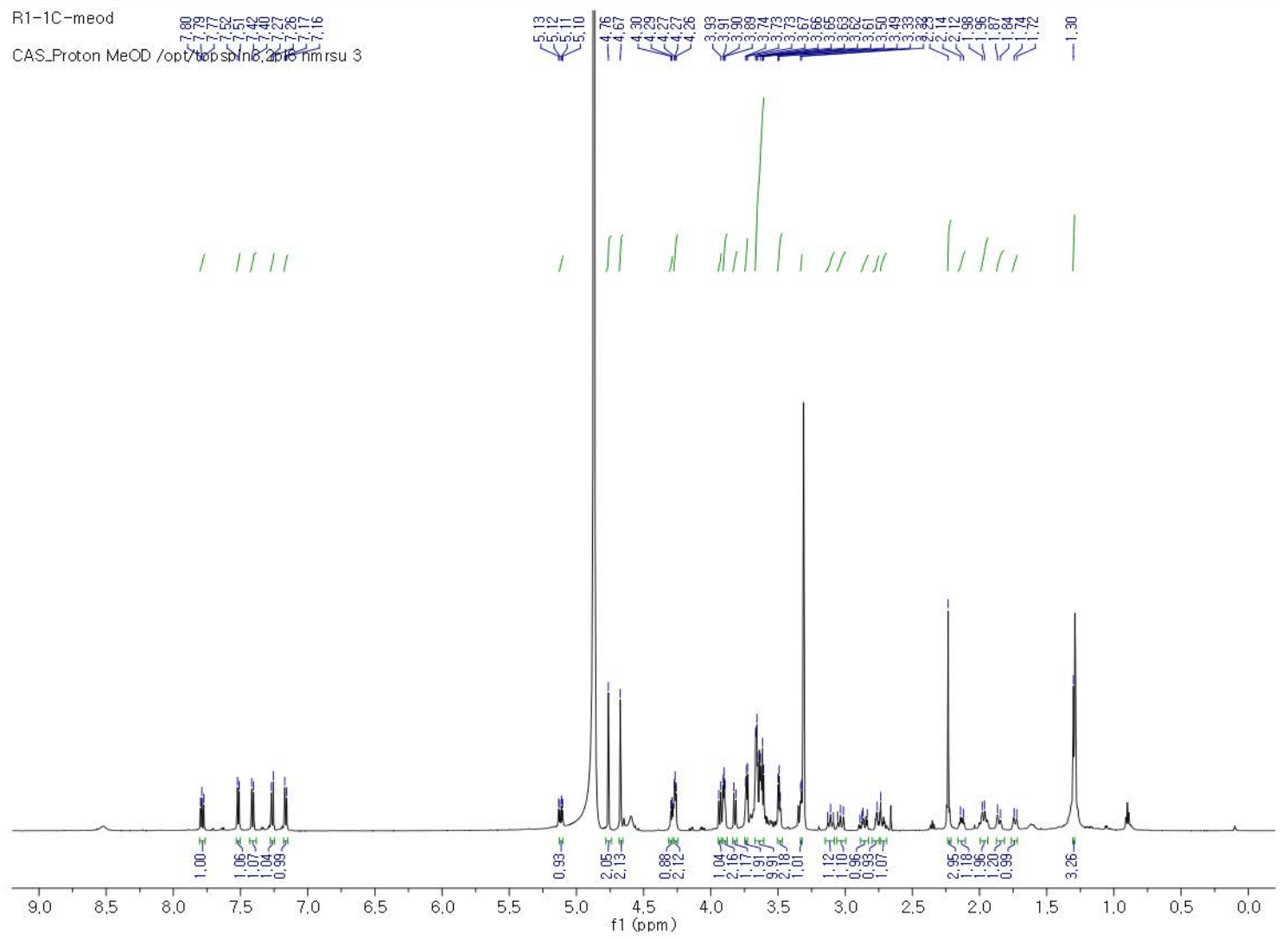

Figure S11. ${ }^{1} \mathrm{H}$ NMR spectrum of R1-1C in MeOH- $d_{4}$.

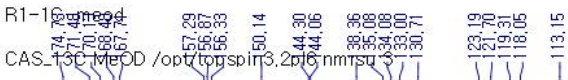
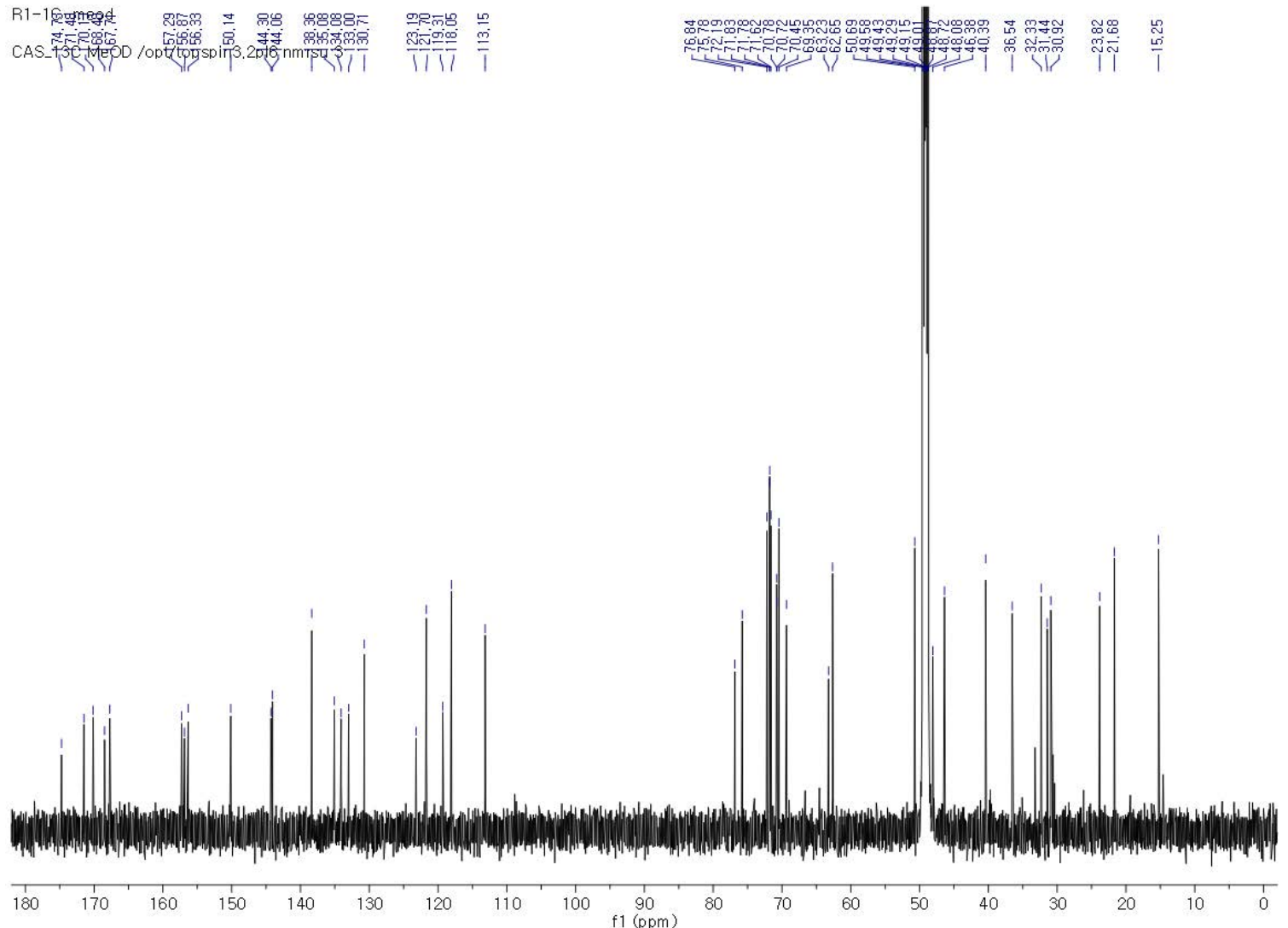

Figure S12. ${ }^{13} \mathrm{C}$ NMR spectrum of R1-1C in MeOH- $d_{4}$. 
bioRxiv preprint doi: https://doi.org/10.1101/2021.06.02.446786; this version posted June 2, 2021. The copyright holder for this preprint (which was not certified by peer review) is the author/funder, who has granted bioRxiv a license to display the preprint in perpetuity. It is made available under aCC-BY-NC 4.0 International license.

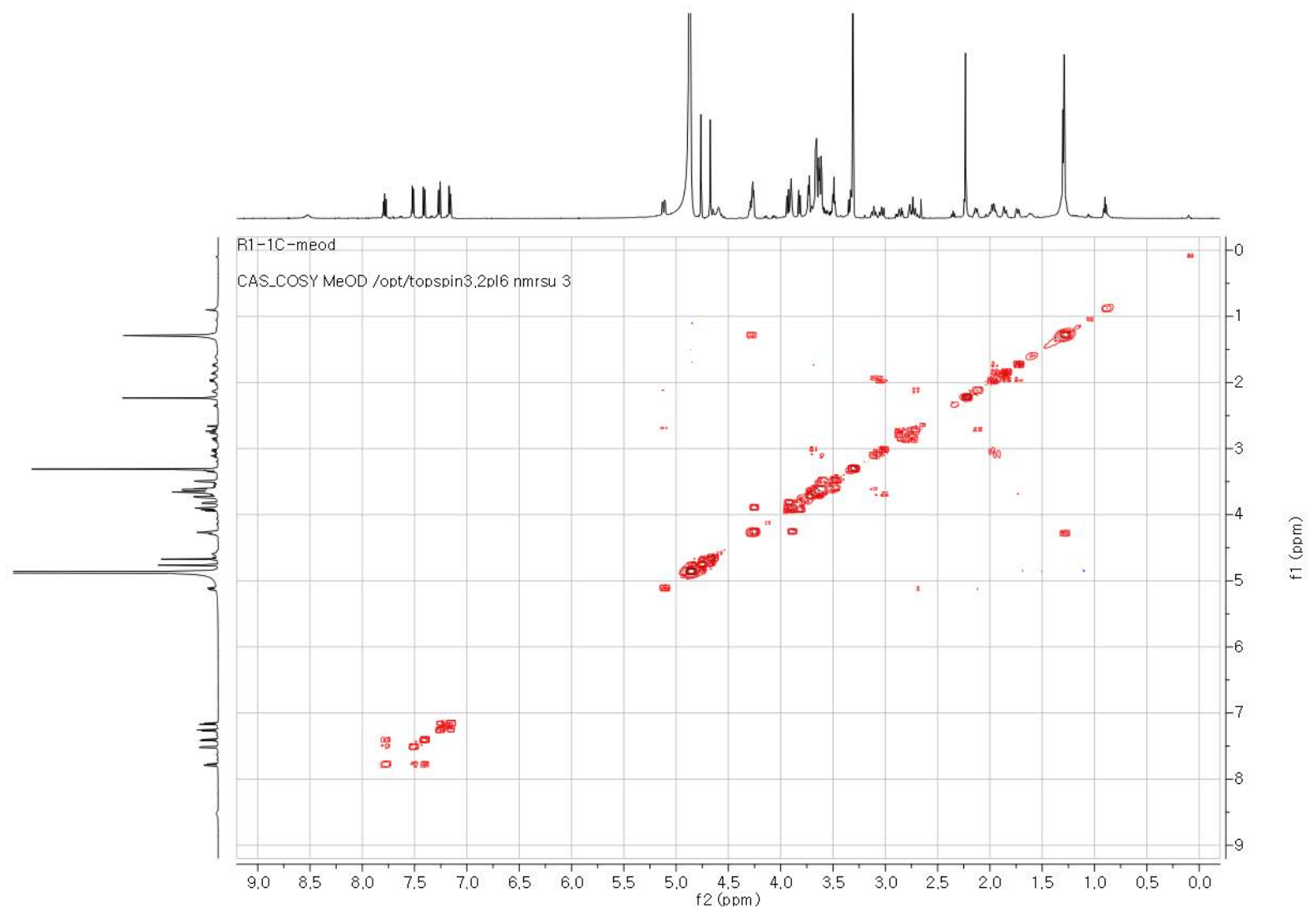

Figure S13. COSY NMR spectrum of R1-1C in MeOH- $d_{4}$

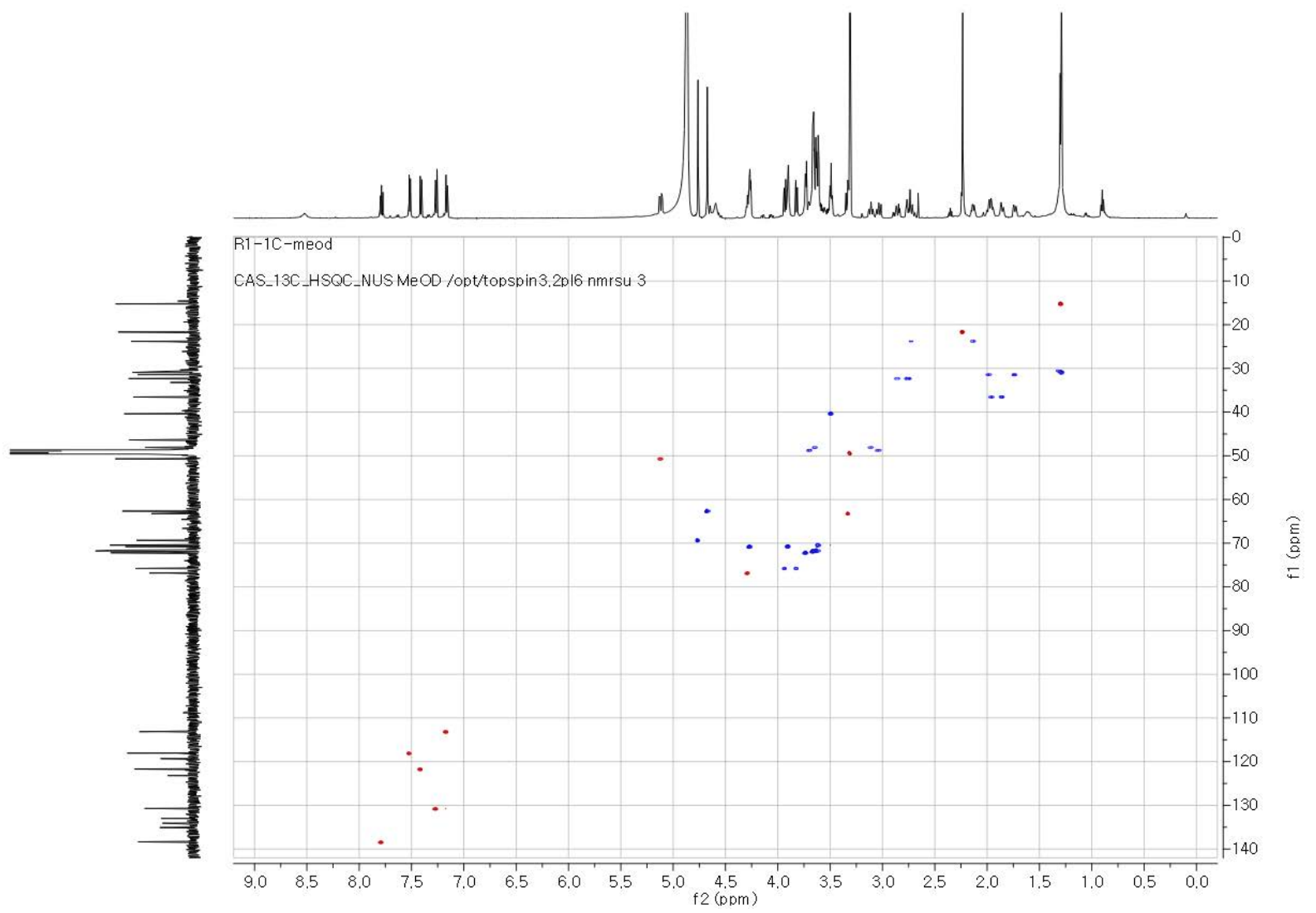

Figure S14. HSQC NMR spectrum of R1-1C in MeOH-d . 
bioRxiv preprint doi: https://doi.org/10.1101/2021.06.02.446786; this version posted June 2, 2021. The copyright holder for this preprint (which was not certified by peer review) is the author/funder, who has granted bioRxiv a license to display the preprint in perpetuity. It is made available under aCC-BY-NC 4.0 International license.

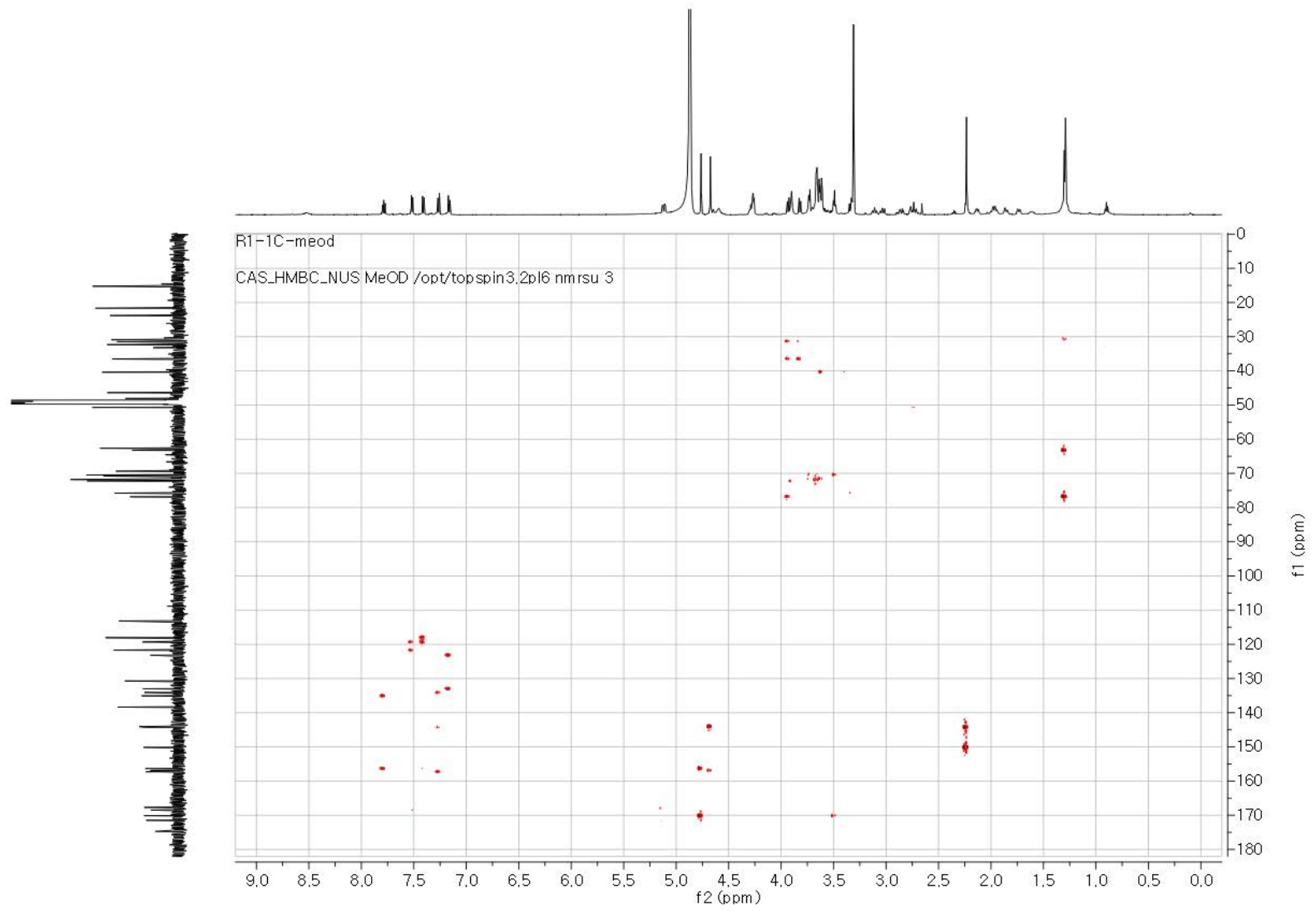

Figure S15. HMBC NMR spectrum of R1-1C in MeOH- $d 4$. 
bioRxiv preprint doi: https://doi.org/10.1101/2021.06.02.446786; this version posted June 2, 2021. The copyright holder for this preprint (which was not certified by peer review) is the author/funder, who has granted bioRxiv a license to display the preprint in perpetuity. It is made available under aCC-BY-NC 4.0 International license.

Table S2. ${ }^{1} \mathrm{H}$ and ${ }^{13} \mathrm{C}$ NMR data of $\mathrm{R} 1-1 \mathrm{C}$ in $\mathrm{MeOH}-d_{4}$.

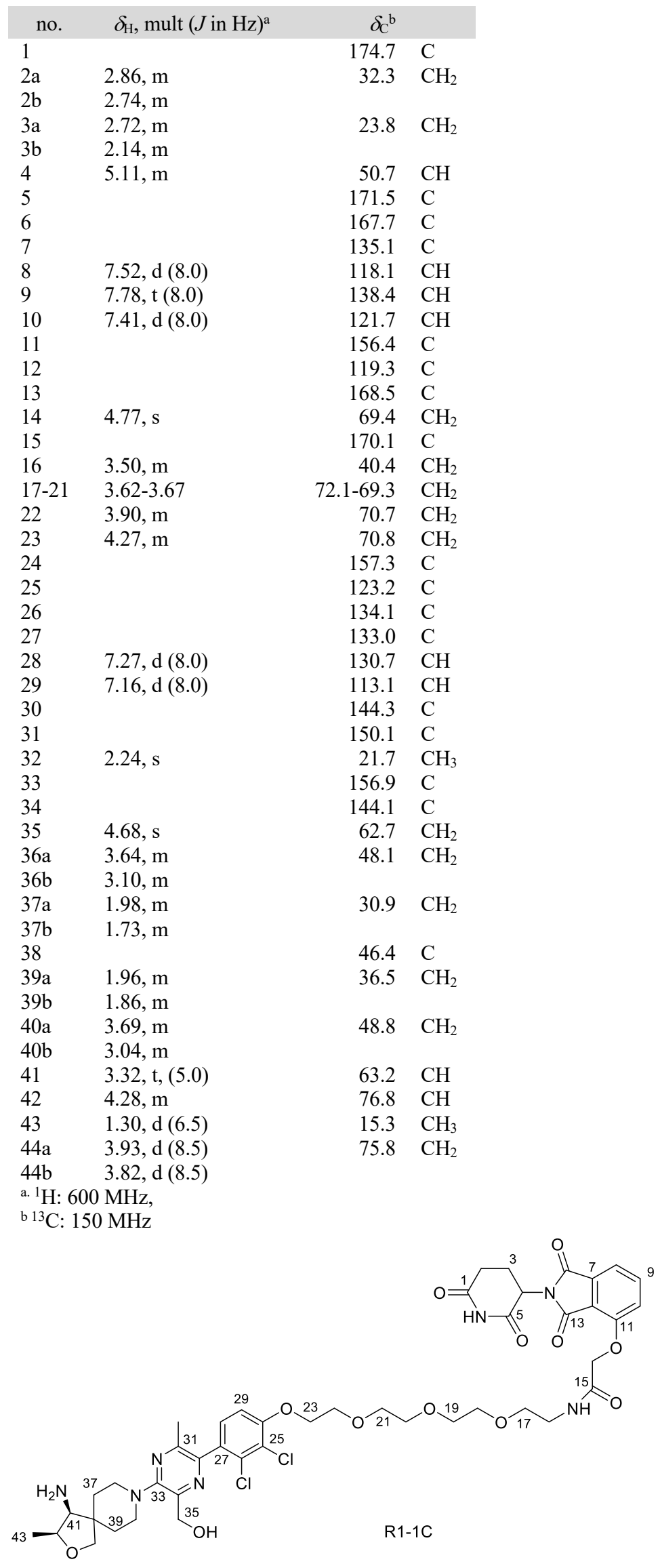


bioRxiv preprint doi: https://doi.org/10.1101/2021.06.02.446786; this version posted June 2, 2021. The copyright holder for this preprint (which was not certified by peer review) is the author/funder, who has granted bioRxiv a license to display the preprint in perpetuity. It is made available under aCC-BY-NC 4.0 International license.

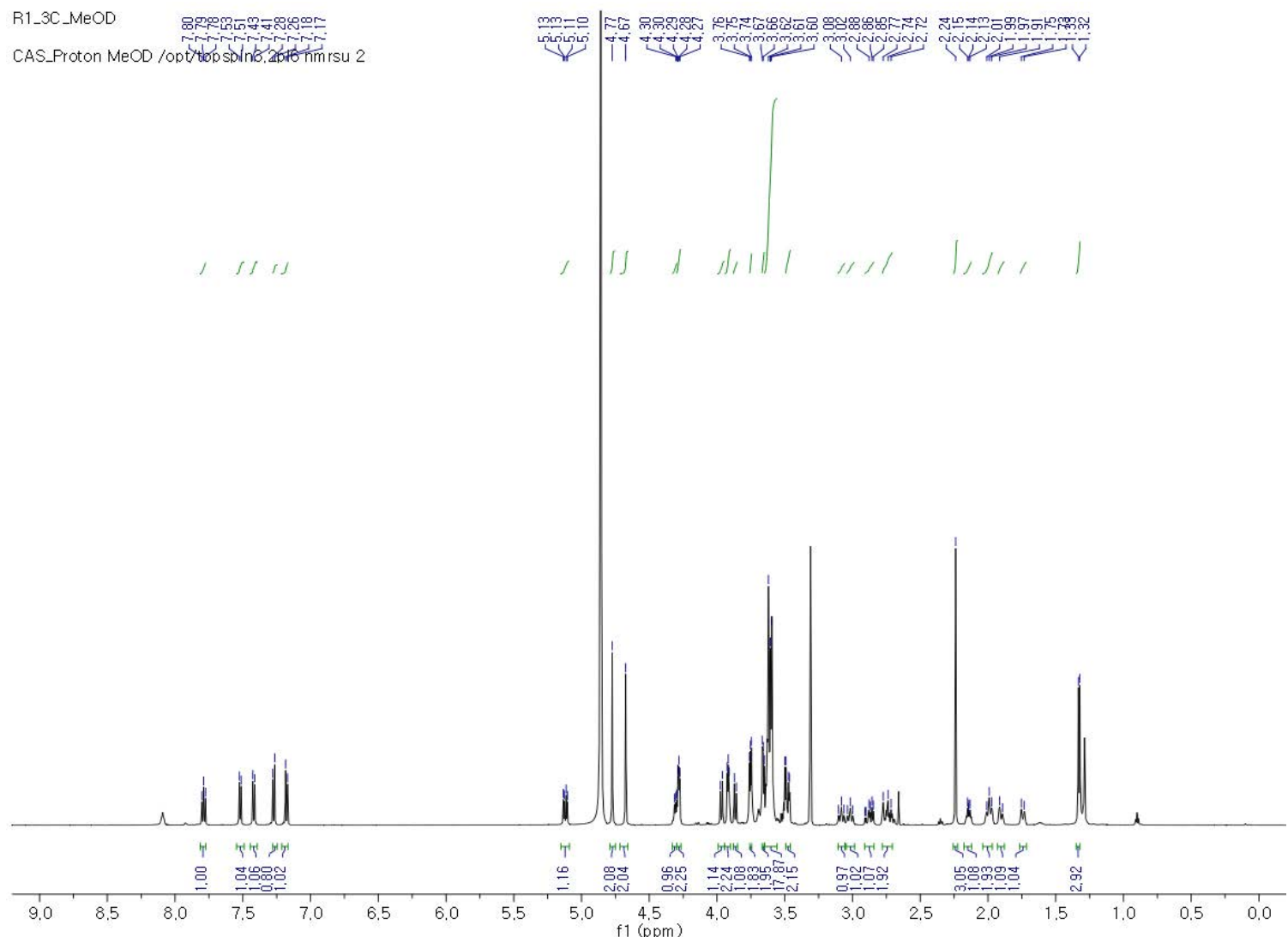

Figure S16. ${ }^{1} \mathrm{H}$ NMR spectrum of R1-3C in MeOH- $d 4$.

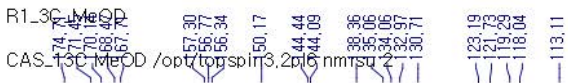
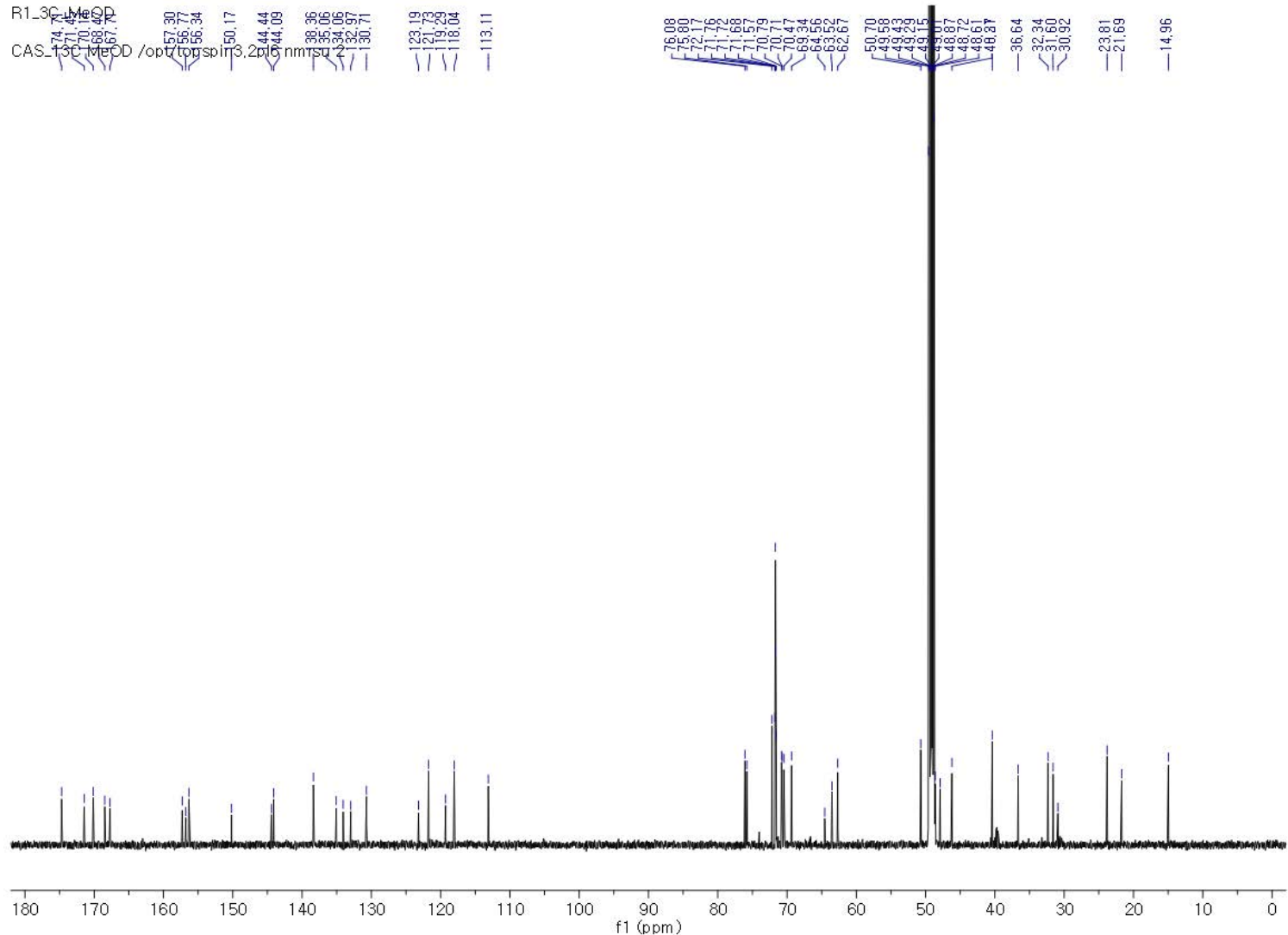

Figure S17. ${ }^{13} \mathrm{C}$ NMR spectrum of R1-3C in MeOH- $d 4$. 
bioRxiv preprint doi: https://doi.org/10.1101/2021.06.02.446786; this version posted June 2, 2021. The copyright holder for this preprint (which was not certified by peer review) is the author/funder, who has granted bioRxiv a license to display the preprint in perpetuity. It is made available under aCC-BY-NC 4.0 International license.

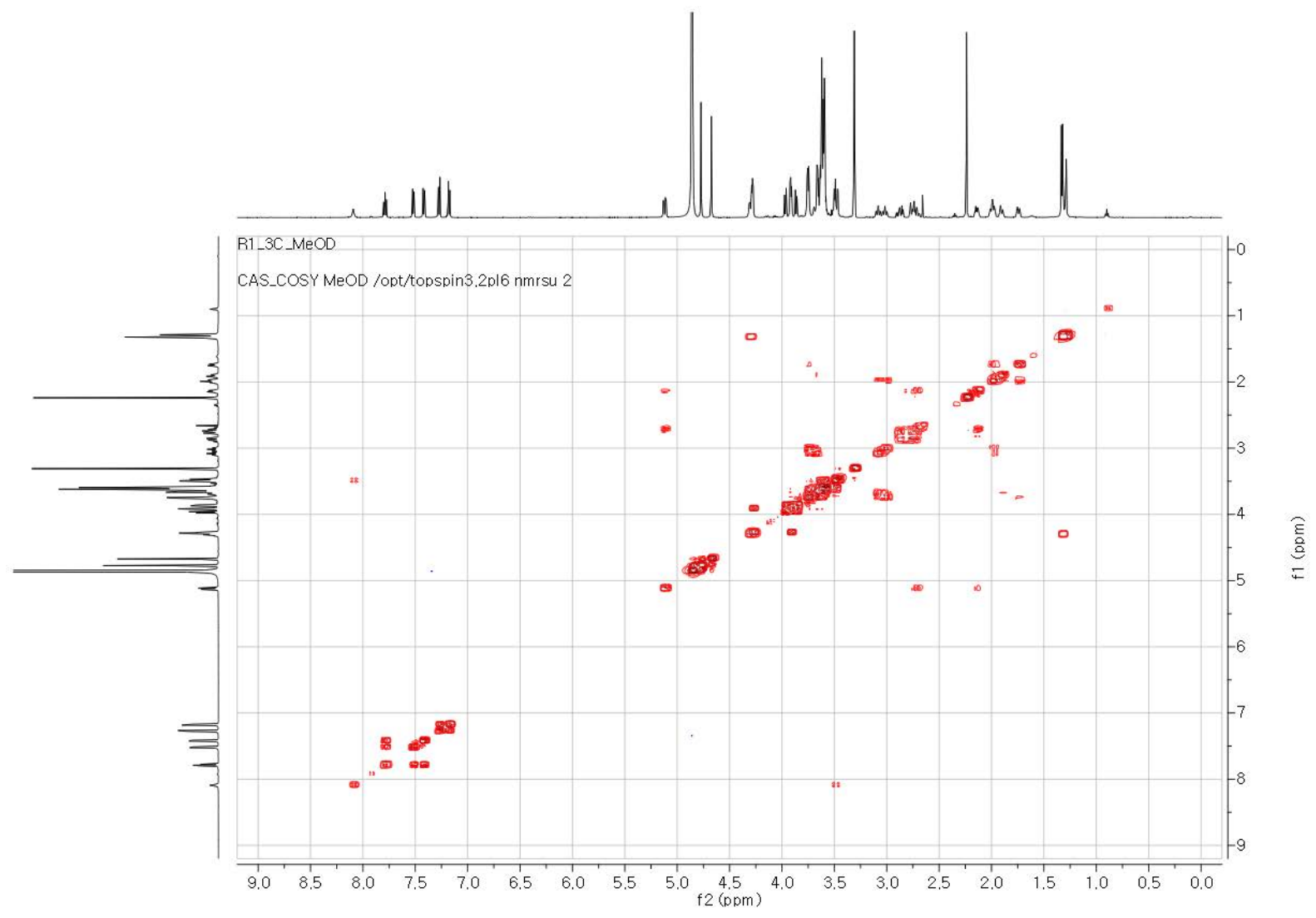

Figure S18. COSY NMR spectrum of R1-3C in MeOH-d4.

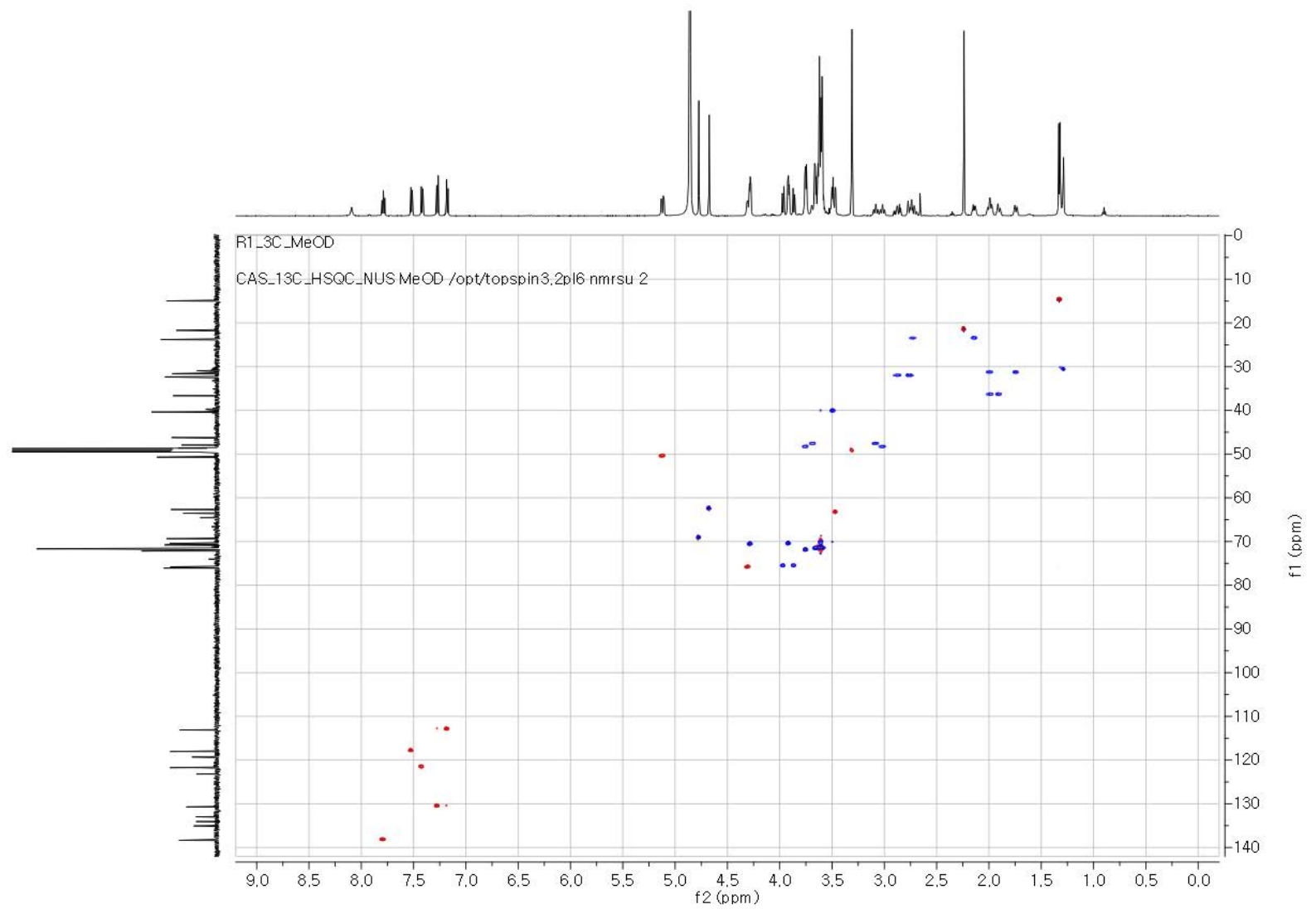

Figure S19. HSQC NMR spectrum of R1-3C in MeOH- $d_{4}$. 
bioRxiv preprint doi: https://doi.org/10.1101/2021.06.02.446786; this version posted June 2, 2021. The copyright holder for this preprint (which was not certified by peer review) is the author/funder, who has granted bioRxiv a license to display the preprint in perpetuity. It is made available under aCC-BY-NC 4.0 International license.

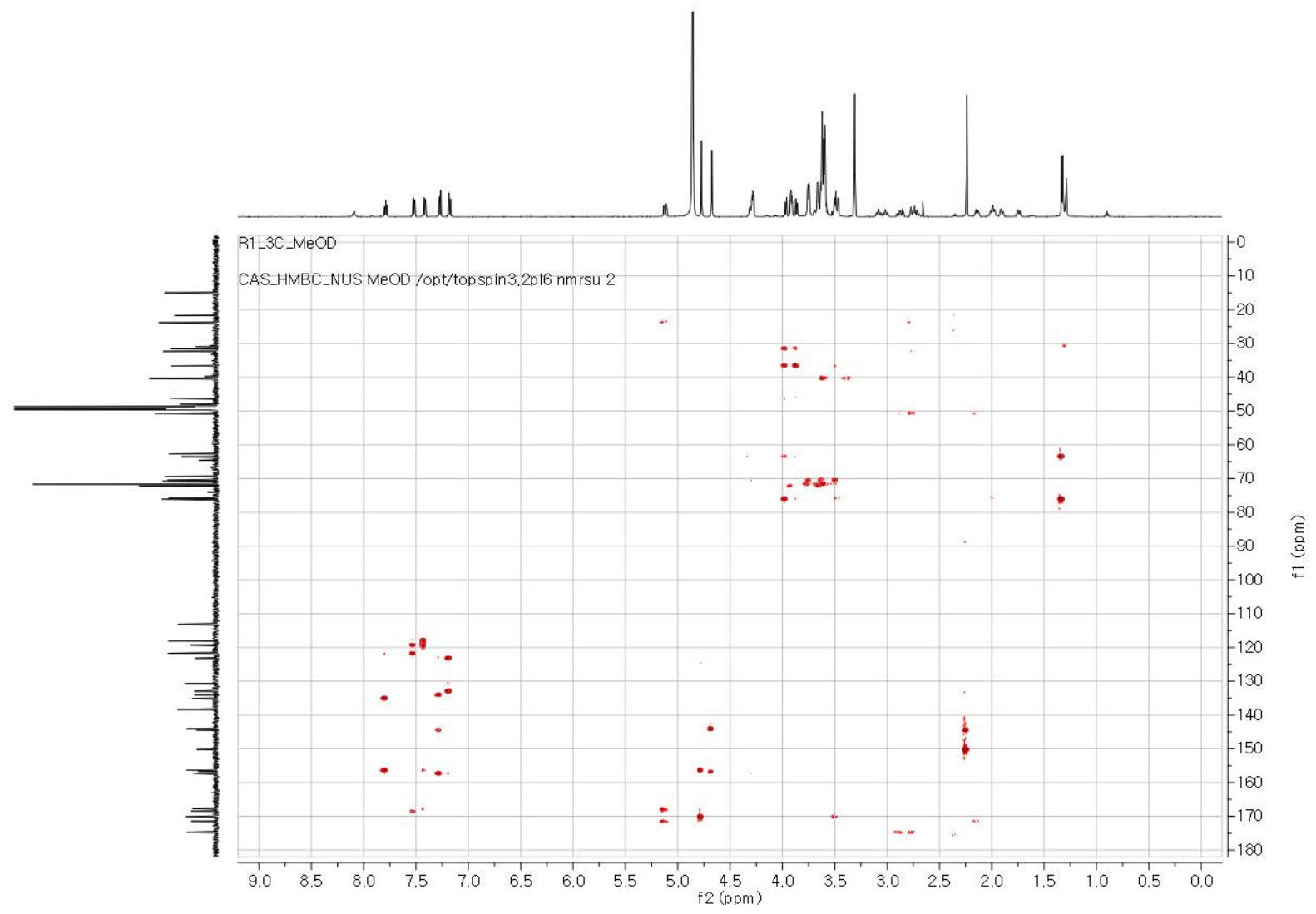

Figure S20. HMBC NMR spectrum of R1-3C in MeOH-d4. 
bioRxiv preprint doi: https://doi.org/10.1101/2021.06.02.446786; this version posted June 2, 2021. The copyright holder for this preprint (which was not certified by peer review) is the author/funder, who has granted bioRxiv a license to display the preprint in perpetuity. It is made available under aCC-BY-NC 4.0 International license.

Table S3. ${ }^{1} \mathrm{H}$ and ${ }^{13} \mathrm{C}$ NMR data of $\mathrm{R} 1-3 \mathrm{C}$ in $\mathrm{MeOH}-d_{4}$.

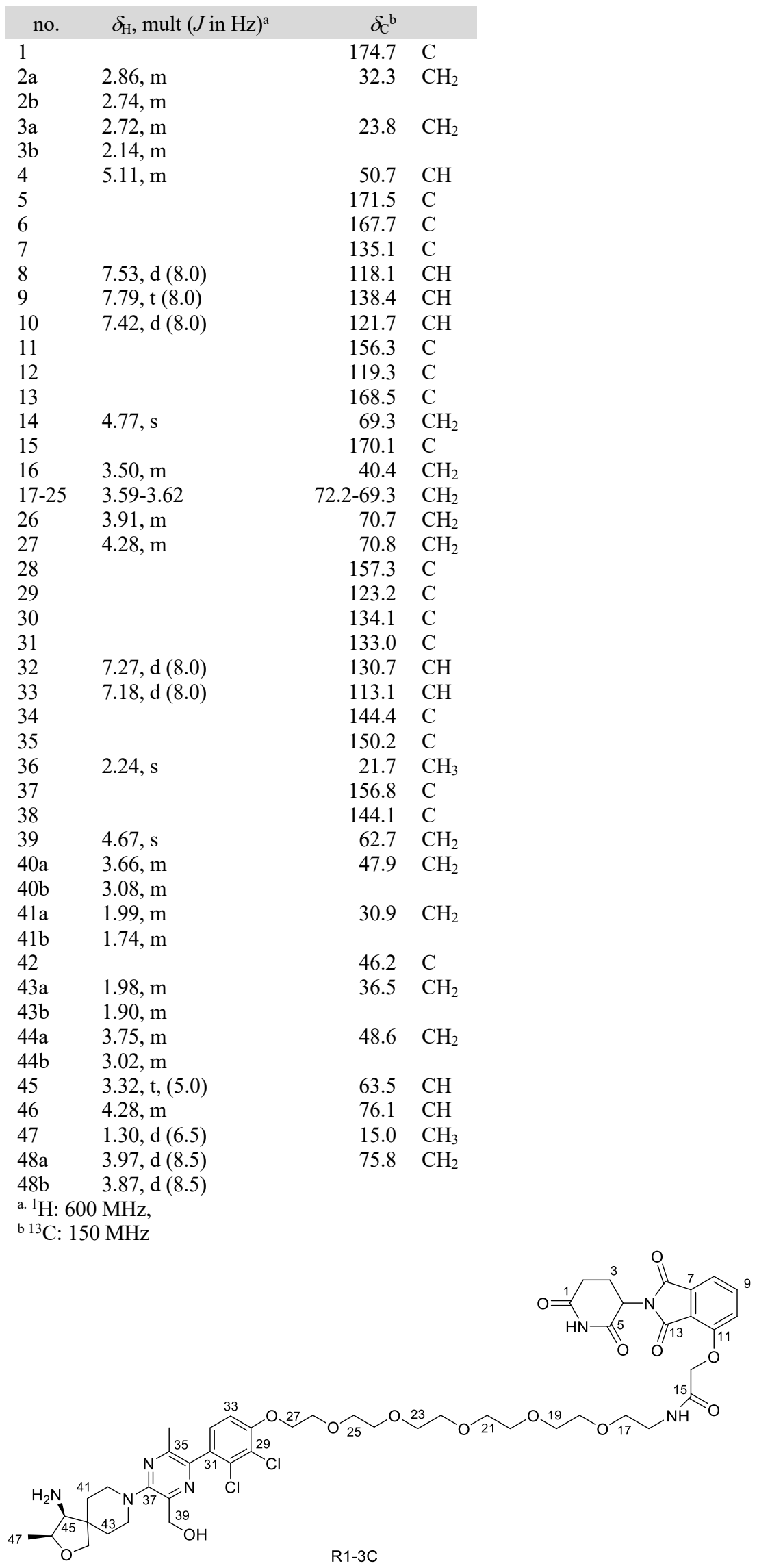


bioRxiv preprint doi: https://doi.org/10.1101/2021.06.02.446786; this version posted June 2, 2021. The copyright holder for this preprint (which was not certified by peer review) is the author/funder, who has granted bioRxiv a license to display the preprint in perpetuity. It is made available under aCC-BY-NC 4.0 International license.

$\mathrm{R} 1-5 \mathrm{C} \_\mathrm{MeOD}$

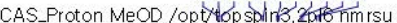

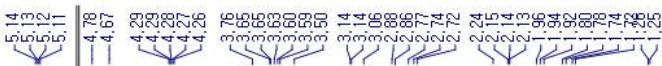
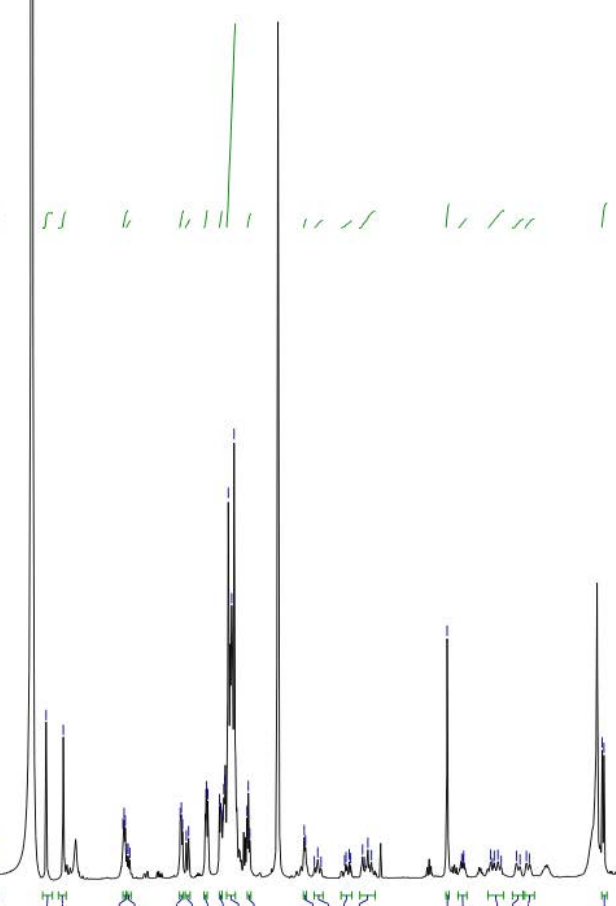
$\bar{y}$

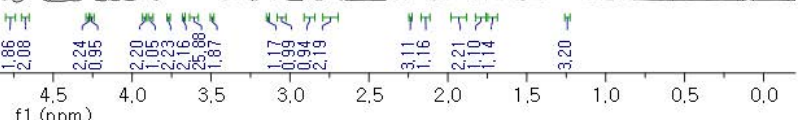

Figure S21. ${ }^{1} \mathrm{H}$ NMR spectrum of $\mathrm{R} 1-5 \mathrm{C}$ in $\mathrm{MeOH}-d 4$.
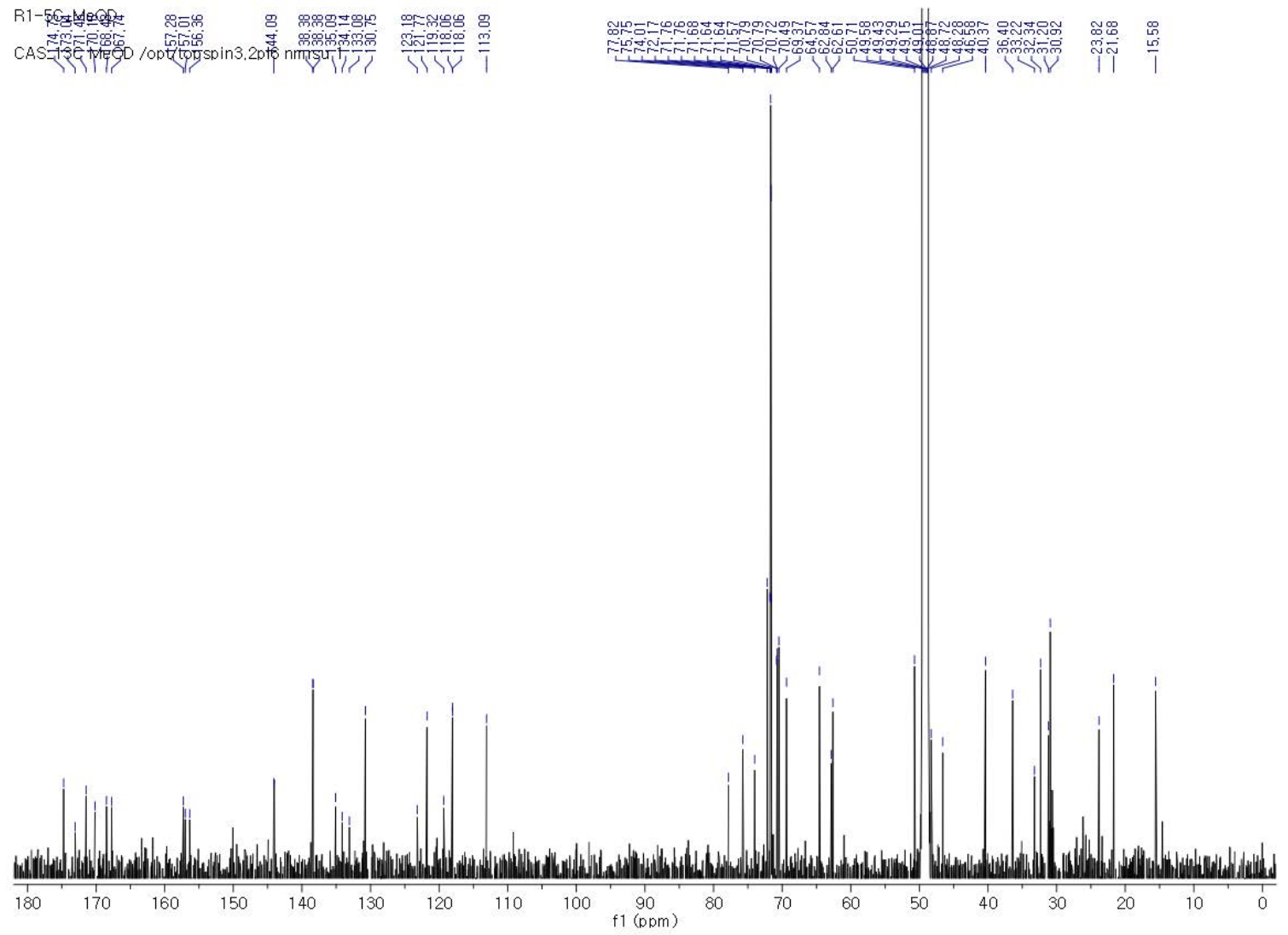

Figure S22. ${ }^{13} \mathrm{C}$ NMR spectrum of R1-5C in MeOH- $d 4$. 
bioRxiv preprint doi: https://doi.org/10.1101/2021.06.02.446786; this version posted June 2, 2021. The copyright holder for this preprint (which was not certified by peer review) is the author/funder, who has granted bioRxiv a license to display the preprint in perpetuity. It is made available under aCC-BY-NC 4.0 International license.

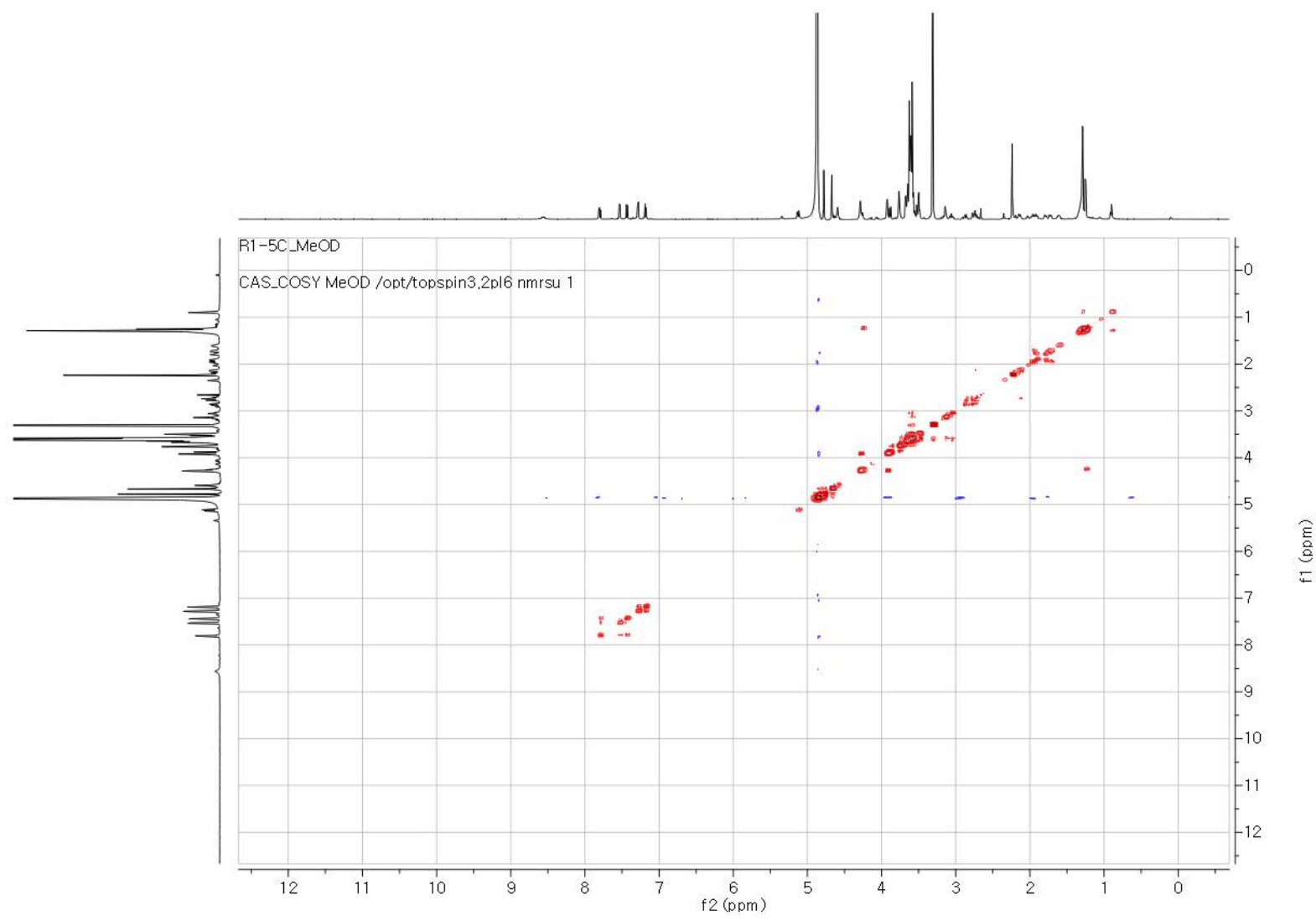

Figure S23. COSY NMR spectrum of R1-5C in MeOH-d $d_{4}$

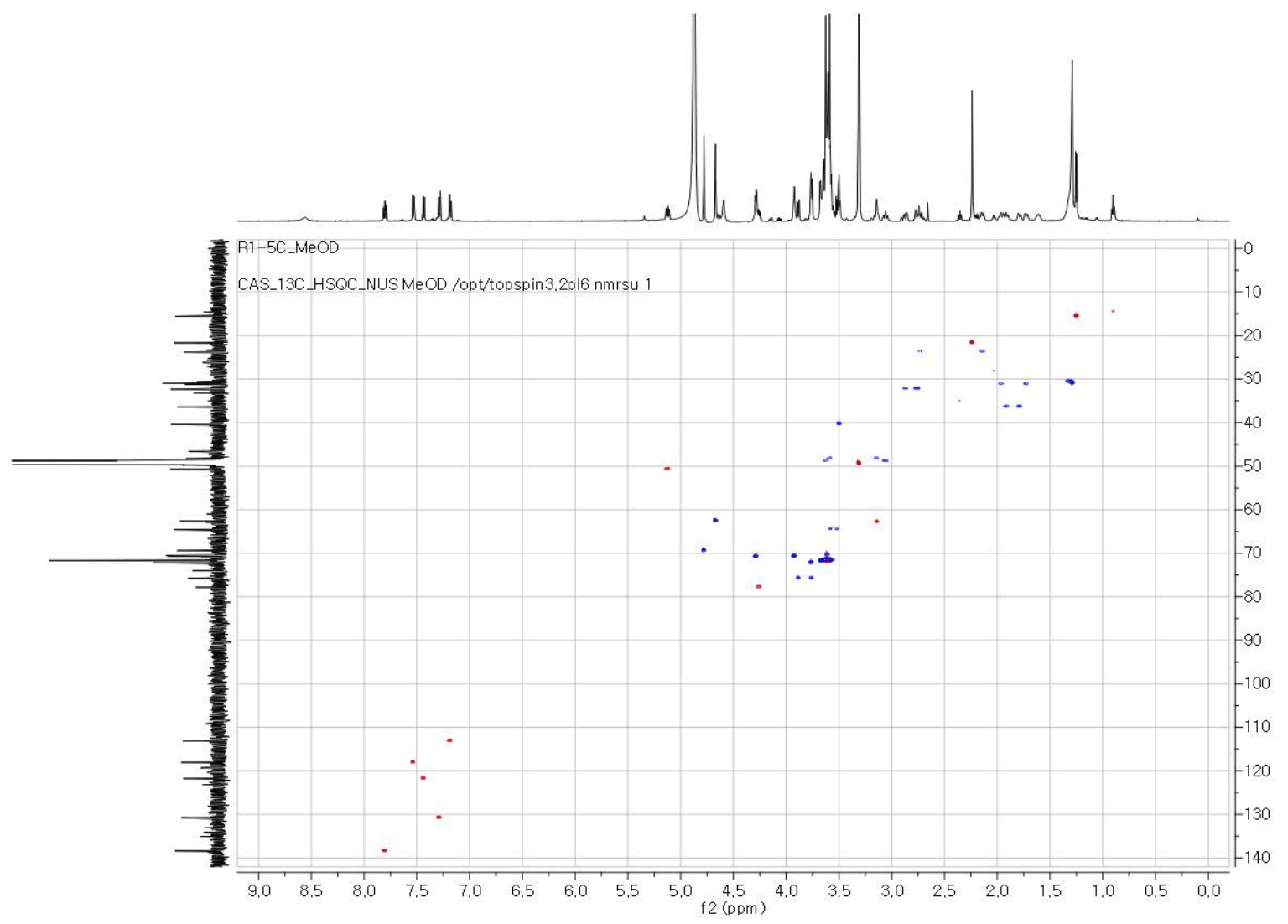

Figure S24. HSQC NMR spectrum of R1-5C in MeOH-d4. 
bioRxiv preprint doi: https://doi.org/10.1101/2021.06.02.446786; this version posted June 2, 2021. The copyright holder for this preprint (which was not certified by peer review) is the author/funder, who has granted bioRxiv a license to display the preprint in perpetuity. It is made available under aCC-BY-NC 4.0 International license.

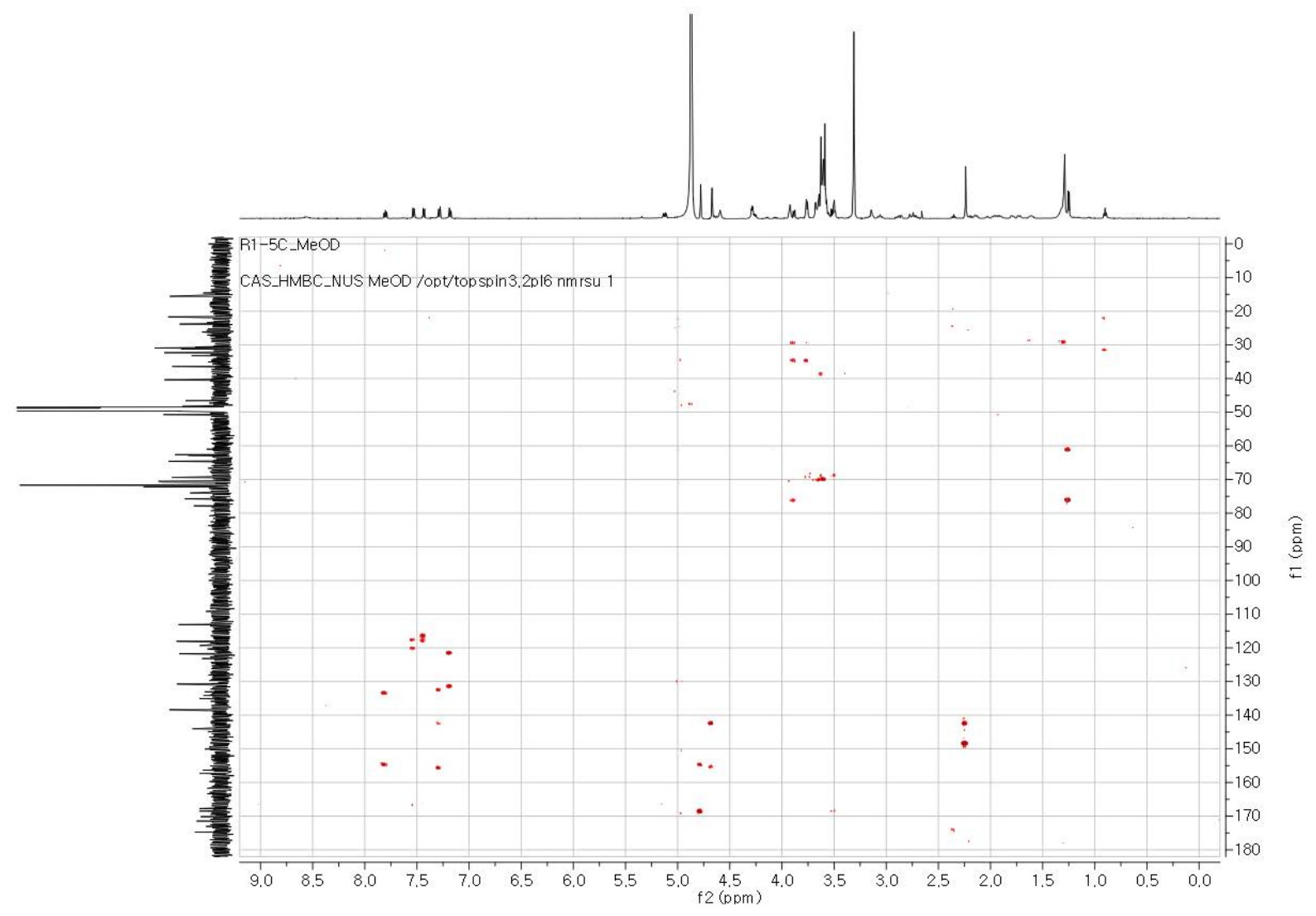

Figure S25. HMBC NMR spectrum of R1-5C in MeOH-d4. 
bioRxiv preprint doi: https://doi.org/10.1101/2021.06.02.446786; this version posted June 2, 2021. The copyright holder for this preprint (which was not certified by peer review) is the author/funder, who has granted bioRxiv a license to display the preprint in perpetuity. It is made available under aCC-BY-NC 4.0 International license.

Table S4. ${ }^{1} \mathrm{H}$ and ${ }^{13} \mathrm{C}$ NMR data of $\mathrm{R} 1-5 \mathrm{C}$ in $\mathrm{MeOH}-d_{4}$.

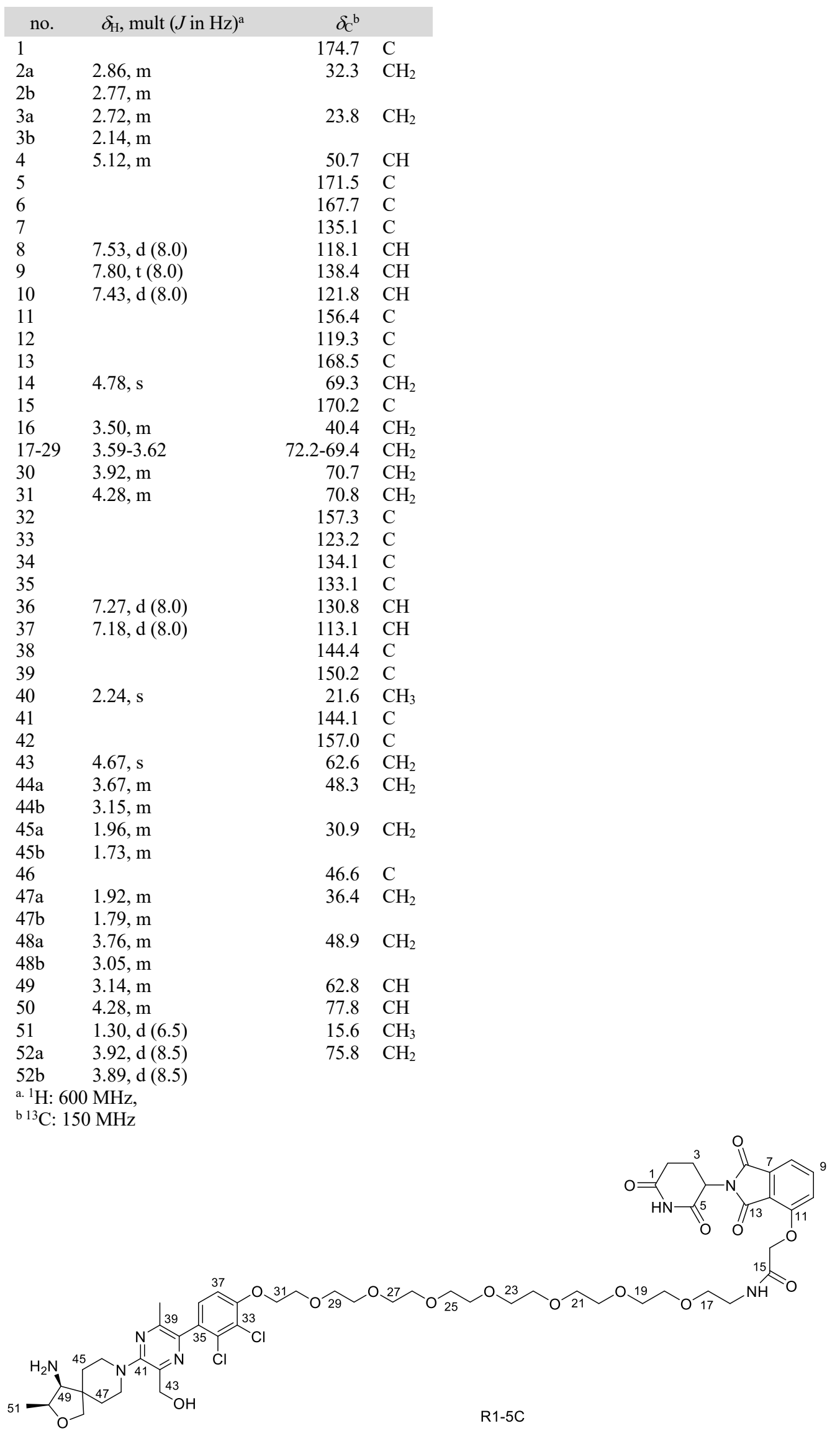


bioRxiv preprint doi: https://doi.org/10.1101/2021.06.02.446786; this version posted June 2, 2021. The copyright holder for this preprint (which was not certified by peer review) is the author/funder, who has granted bioRxiv a license to display the preprint in perpetuity. It is made available under aCC-BY-NC 4.0 International license.

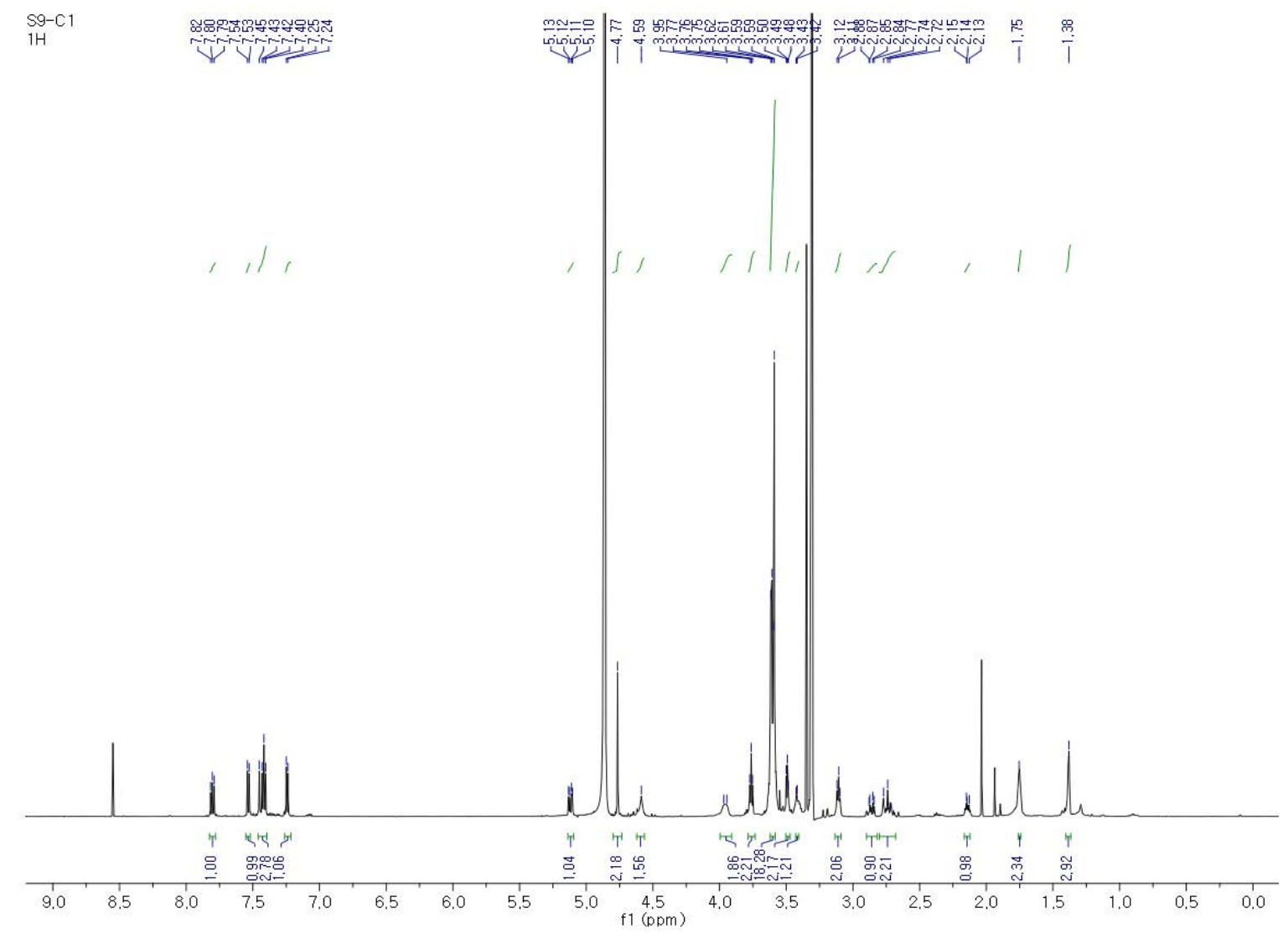

Figure S26. ${ }^{1} \mathrm{H}$ NMR spectrum of S9-1C in MeOH-d4.
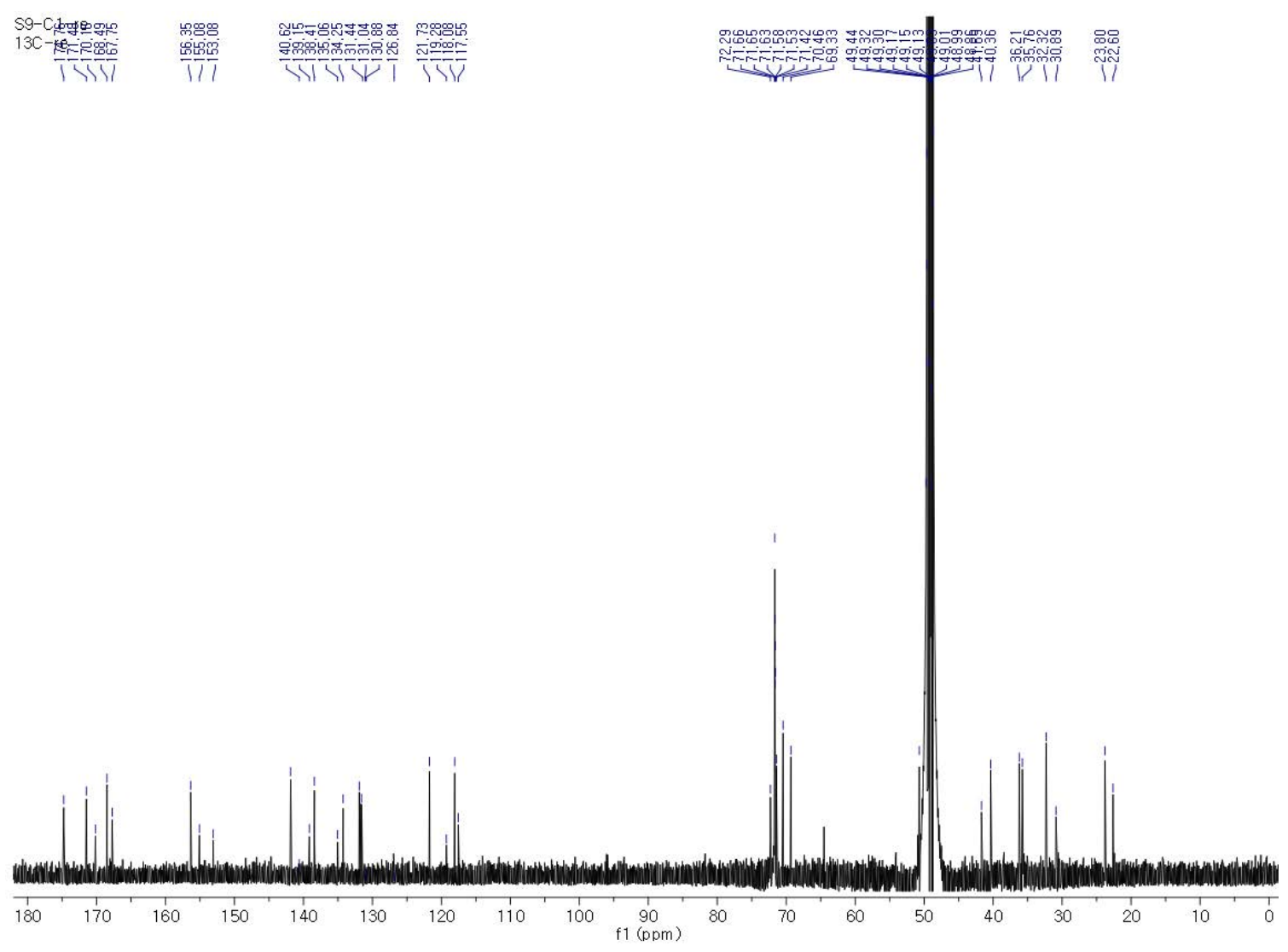

Figure S27. ${ }^{13} \mathrm{C}$ NMR spectrum of S9-1C in MeOH- $d 4$. 
bioRxiv preprint doi: https://doi.org/10.1101/2021.06.02.446786; this version posted June 2, 2021. The copyright holder for this preprint (which was not certified by peer review) is the author/funder, who has granted bioRxiv a license to display the preprint in perpetuity. It is made available under aCC-BY-NC 4.0 International license.

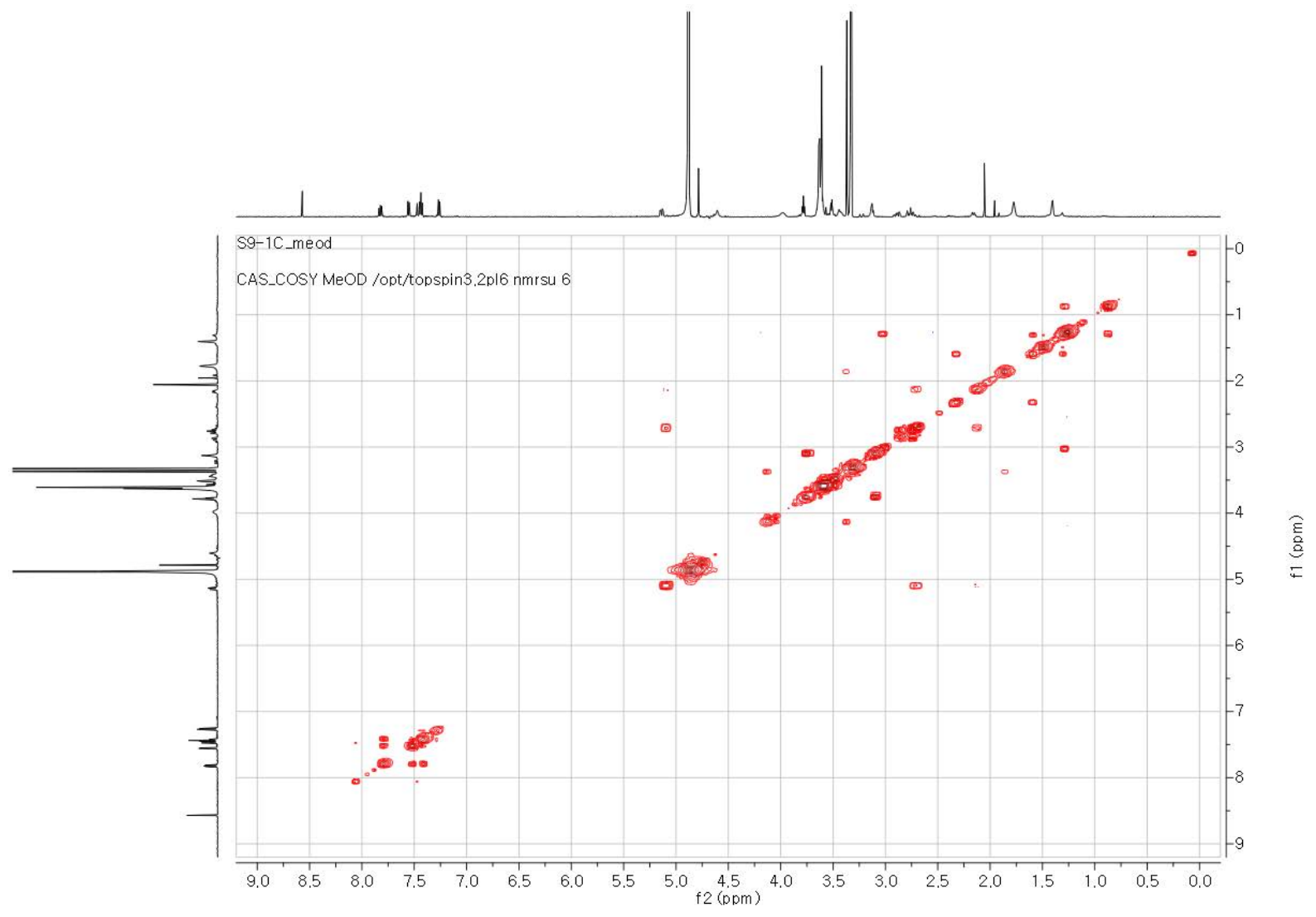

Figure S28. COSY NMR spectrum of S9-1C in MeOH-d4.

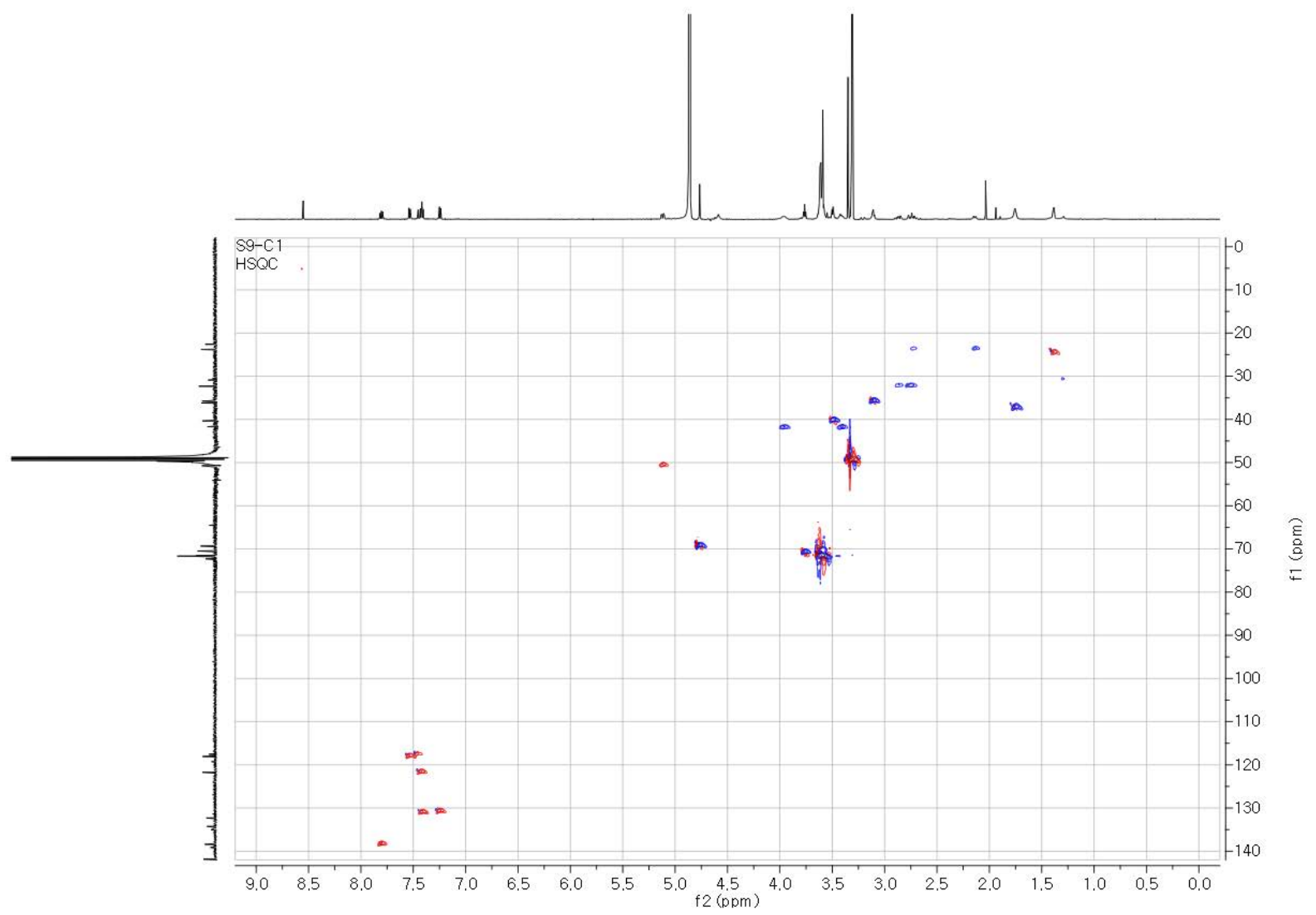

Figure S29. HSQC NMR spectrum of S9-1C in MeOH-d4. 
bioRxiv preprint doi: https://doi.org/10.1101/2021.06.02.446786; this version posted June 2, 2021. The copyright holder for this preprint (which was not certified by peer review) is the author/funder, who has granted bioRxiv a license to display the preprint in perpetuity. It is made available under aCC-BY-NC 4.0 International license.

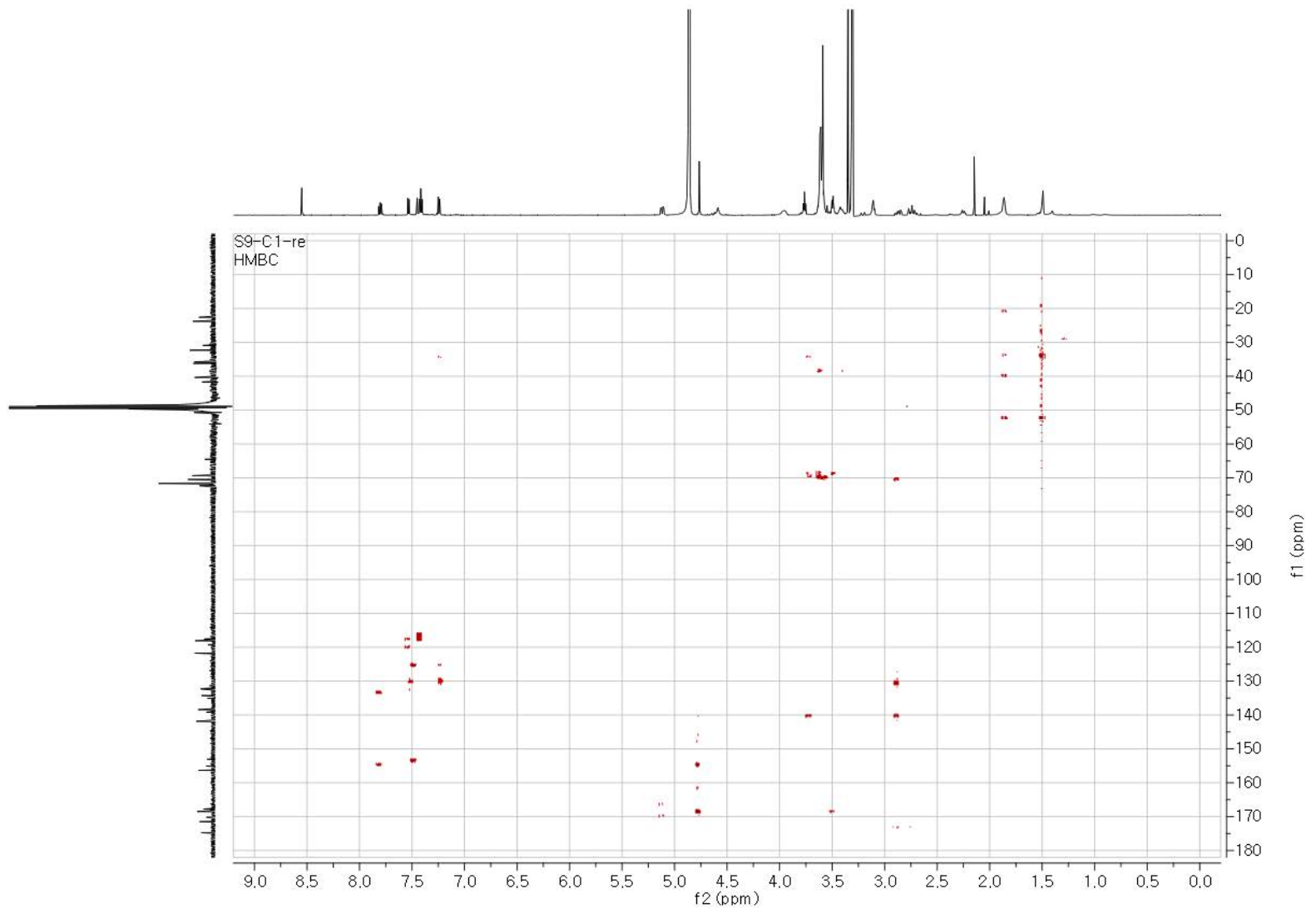

Figure S30. HMBC NMR spectrum of S9-1C in MeOH- $d_{4}$. 
bioRxiv preprint doi: https://doi.org/10.1101/2021.06.02.446786; this version posted June 2, 2021. The copyright holder for this preprint (which was not certified by peer review) is the author/funder, who has granted bioRxiv a license to display the preprint in perpetuity. It is made available under aCC-BY-NC 4.0 International license.

Table S5. ${ }^{1} \mathrm{H}$ and ${ }^{13} \mathrm{C}$ NMR data of $\mathrm{S} 9-1 \mathrm{C}$ in $\mathrm{MeOH}-d_{4}$.

\begin{tabular}{|c|c|c|c|}
\hline no. & $\delta_{\mathrm{H}}$, mult $(J \text { in } \mathrm{Hz})^{\mathrm{a}}$ & $\delta_{\mathrm{C}}^{\mathrm{b}}$ & \\
\hline 1 & & 174.7 & $\mathrm{C}$ \\
\hline $2 \mathrm{a}$ & $2.86, \mathrm{~m}$ & 32.3 & $\mathrm{CH}_{2}$ \\
\hline $2 b$ & $2.74, \mathrm{~m}$ & & \\
\hline $3 a$ & $2.72, \mathrm{~m}$ & 23.8 & $\mathrm{CH}_{2}$ \\
\hline $3 b$ & $2.14, \mathrm{~m}$ & & \\
\hline 4 & $5.11, \mathrm{~m}$ & 50.7 & $\mathrm{CH}$ \\
\hline 5 & & 171.5 & $\mathrm{C}$ \\
\hline 6 & & 167.7 & $\mathrm{C}$ \\
\hline 7 & & 135.0 & $\mathrm{C}$ \\
\hline 8 & $7.53, \mathrm{~d}(8.0)$ & 118.1 & $\mathrm{CH}$ \\
\hline 9 & $7.80, \mathrm{t}(8.0)$ & 138.4 & $\mathrm{CH}$ \\
\hline 10 & $7.42, \mathrm{~d}(8.0)$ & 121.7 & $\mathrm{CH}$ \\
\hline 11 & & 156.4 & $\mathrm{C}$ \\
\hline 12 & & 119.3 & $\mathrm{C}$ \\
\hline 13 & & 168.5 & $\mathrm{C}$ \\
\hline 14 & $4.77, \mathrm{~s}$ & 69.4 & $\mathrm{CH}_{2}$ \\
\hline 15 & & 170.1 & $\mathrm{C}$ \\
\hline 16 & $3.50, \mathrm{~m}$ & 40.4 & $\mathrm{CH}_{2}$ \\
\hline $17-25$ & $3.55-3.61$ & $71.7-71.3$ & $\mathrm{CH}_{2}$ \\
\hline 26 & $3.76, \mathrm{t}(7.0)$ & 70.6 & $\mathrm{CH}_{2}$ \\
\hline 27 & $3.10, \mathrm{t}(7.0)$ & 35.7 & $\mathrm{CH}_{2}$ \\
\hline 28 & & 140.6 & $\mathrm{C}$ \\
\hline 29 & & 134.4 & $\mathrm{C}$ \\
\hline 30 & & 135.1 & $\mathrm{C}$ \\
\hline 31 & & 131.4 & $\mathrm{C}$ \\
\hline 32 & $7.43, \mathrm{~d}(8.0)$ & 131.0 & $\mathrm{CH}$ \\
\hline 33 & $7.24, \mathrm{~d}(8.0)$ & 130.9 & $\mathrm{CH}$ \\
\hline 34 & & 126.8 & $\mathrm{C}$ \\
\hline 35 & & 153.1 & $\mathrm{C}$ \\
\hline 36 & & 155.5 & $\mathrm{C}$ \\
\hline 37 & $7.46, \mathrm{~s}$ & 117.4 & $\mathrm{CH}$ \\
\hline $38 \mathrm{a}, 42 \mathrm{a}$ & $3.96, \mathrm{~m}$ & 41.7 & $\mathrm{CH}_{2}$ \\
\hline $38 b, 42 b$ & $3.40, \mathrm{~m}$ & & \\
\hline 39,41 & $1.76, \mathrm{~m}$ & 36.8 & $\mathrm{CH}_{2}$ \\
\hline 40 & & 54.1 & $\mathrm{C}$ \\
\hline 43 & $1.40, \mathrm{~s}$ & 22.6 & $\mathrm{CH}_{3}$ \\
\hline a. ${ }^{1} \mathrm{H}: 6 \mathrm{C}$ & MHz, & & \\
\hline
\end{tabular}<smiles>CC1(N)CCN(c2cnc(-c3ccc(CCOCCOCCOCCOCCOCCNC(=O)COc4cccc5c4C(=O)N(C4CCC(=O)NC4=O)C5=O)c(Cl)c3Cl)c(N)n2)CC1</smiles> 
bioRxiv preprint doi: https://doi.org/10.1101/2021.06.02.446786; this version posted June 2, 2021. The copyright holder for this preprint (which was not certified by peer review) is the author/funder, who has granted bioRxiv a license to display the preprint in perpetuity. It is made available under aCC-BY-NC 4.0 International license.

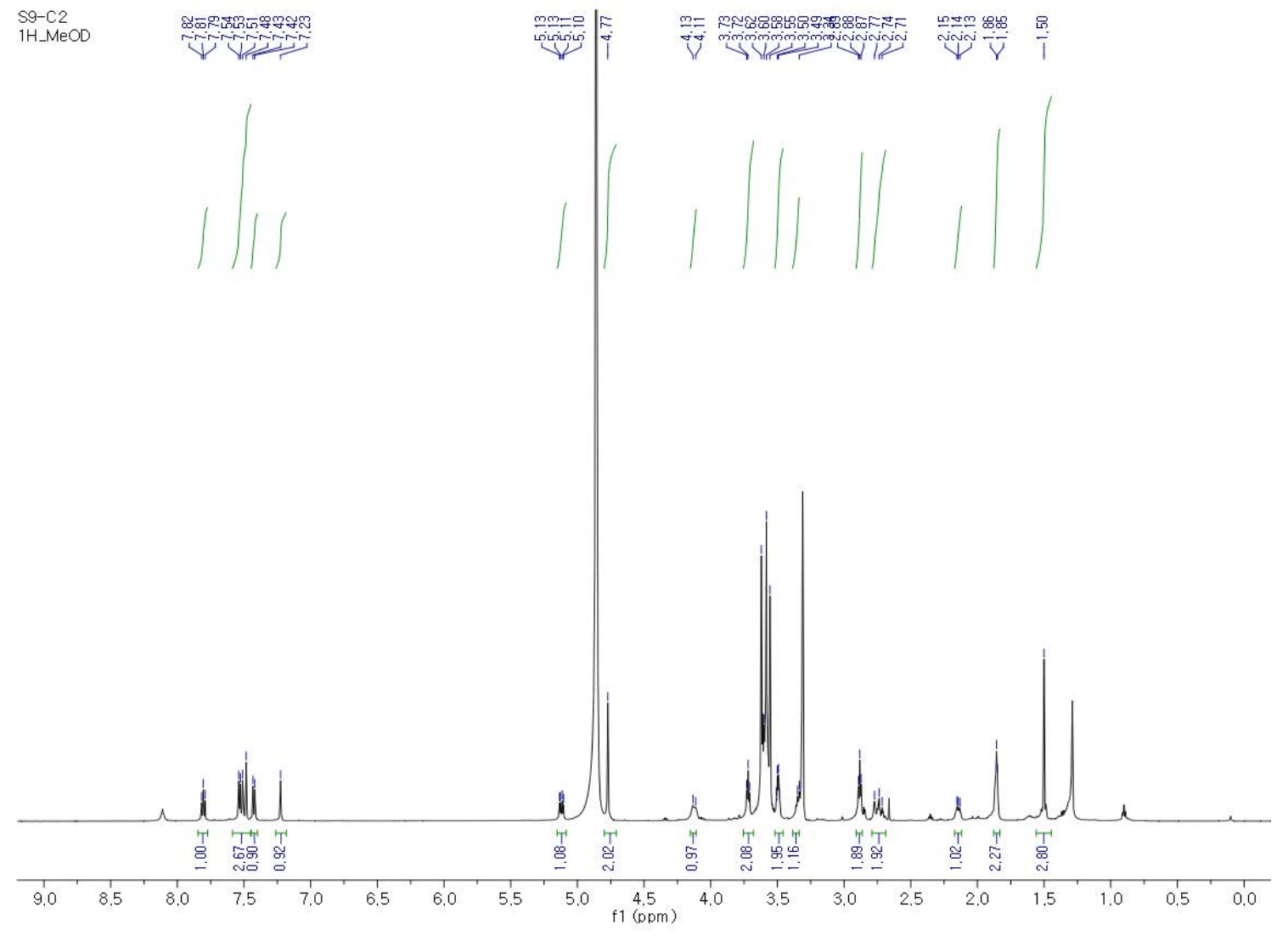

Figure S31. ${ }^{1} \mathrm{H}$ NMR spectrum of S9-2C in MeOH- $d 4$.
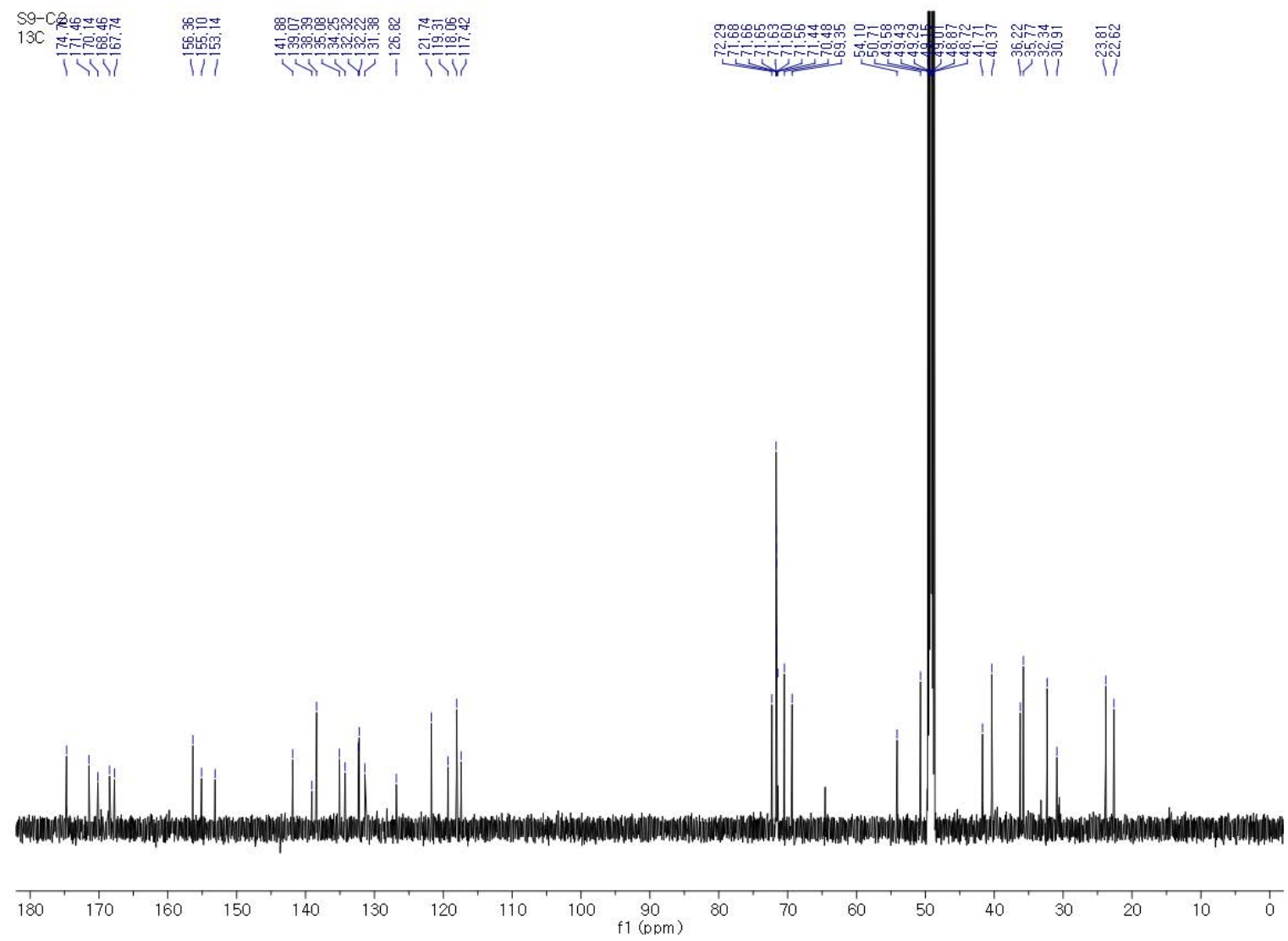

Figure S32. ${ }^{13} \mathrm{C}$ NMR spectrum of S9-2C in MeOH- $d_{4}$. 
bioRxiv preprint doi: https://doi.org/10.1101/2021.06.02.446786; this version posted June 2, 2021. The copyright holder for this preprint (which was not certified by peer review) is the author/funder, who has granted bioRxiv a license to display the preprint in perpetuity. It is made available under aCC-BY-NC 4.0 International license.

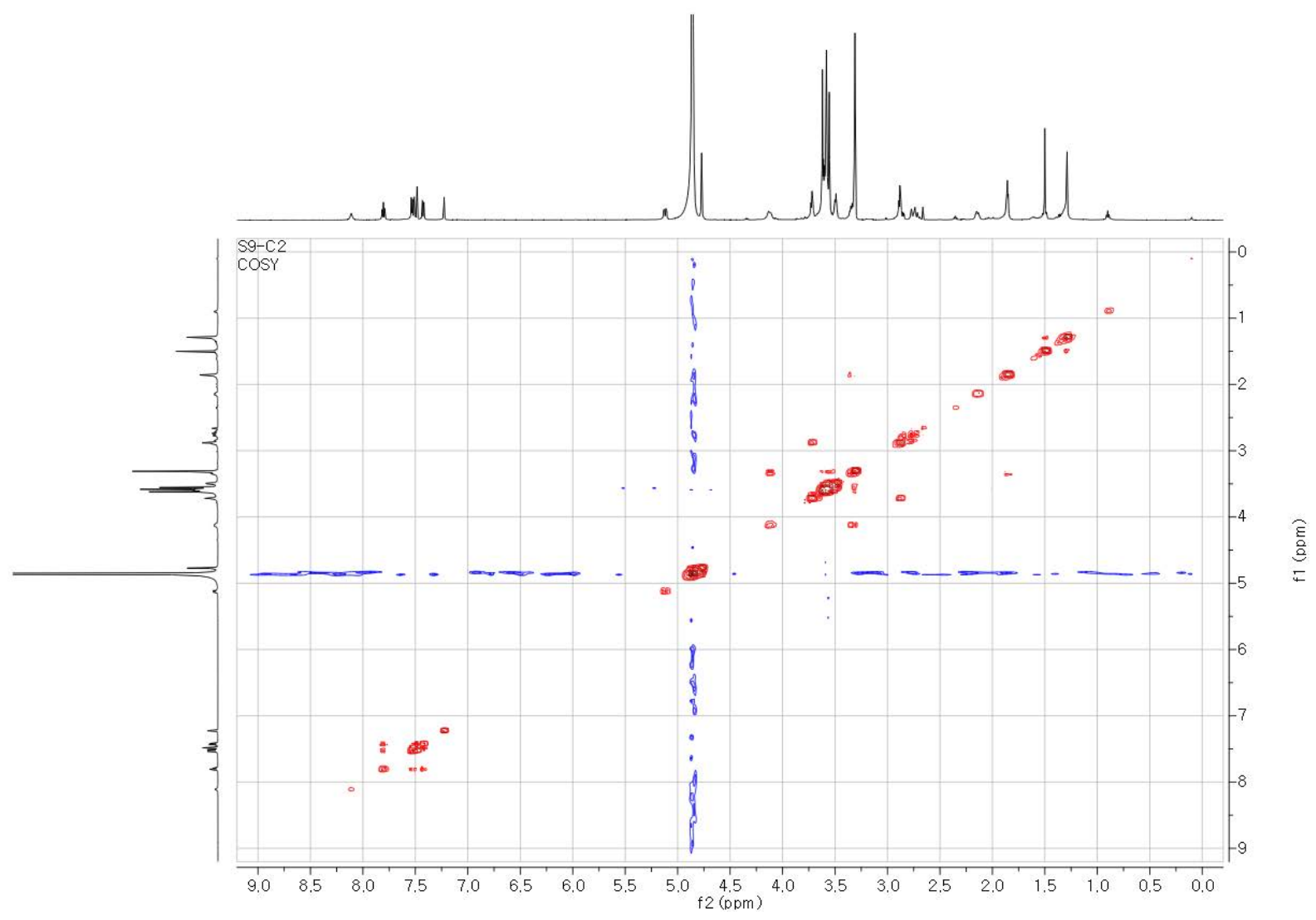

Figure S33. COSY NMR spectrum of S9-2C in MeOH-d4.

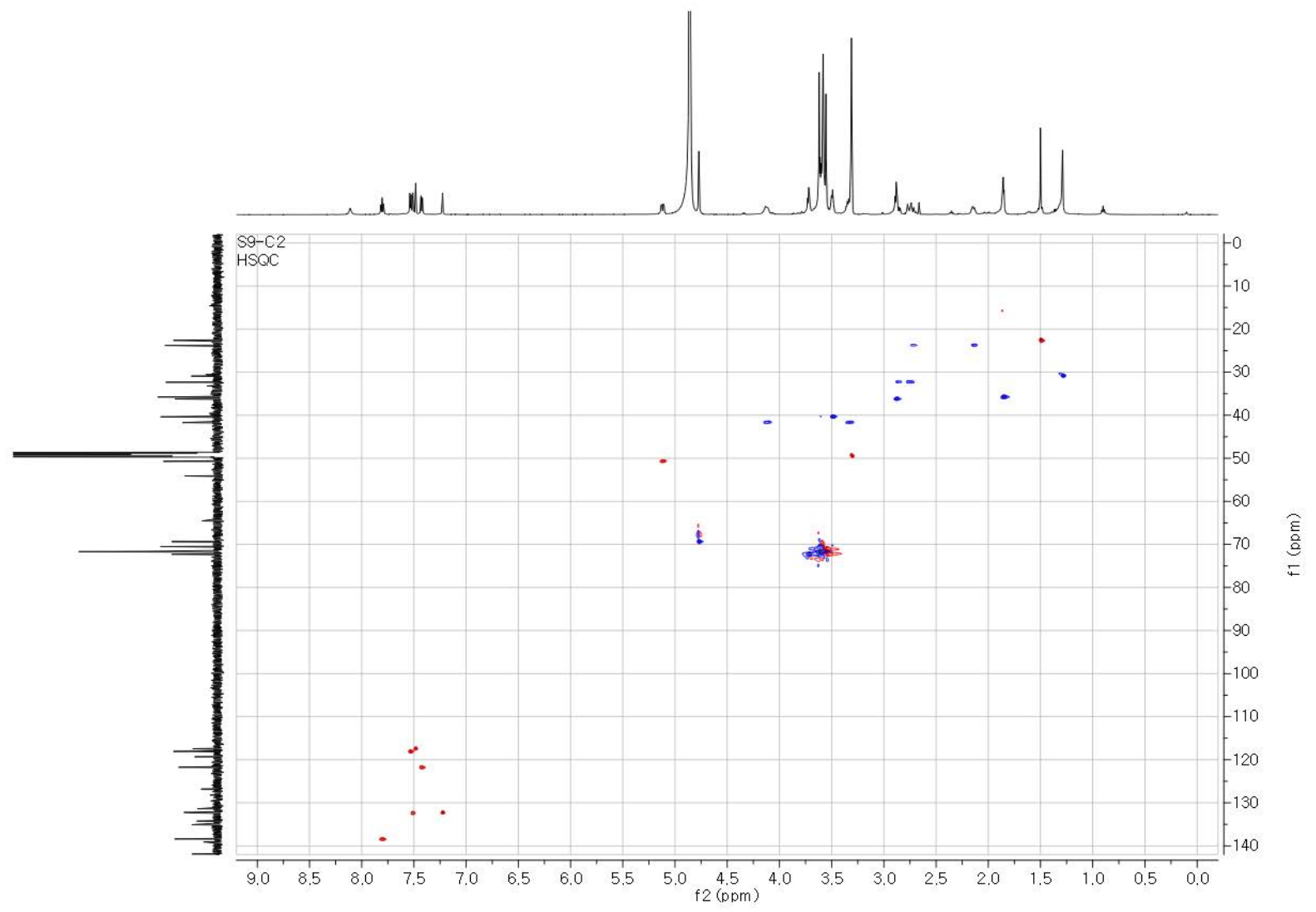

Figure S34. HSQC NMR spectrum of S9-2C in MeOH- $d_{4}$. 
bioRxiv preprint doi: https://doi.org/10.1101/2021.06.02.446786; this version posted June 2, 2021. The copyright holder for this preprint (which was not certified by peer review) is the author/funder, who has granted bioRxiv a license to display the preprint in perpetuity. It is made available under aCC-BY-NC 4.0 International license.

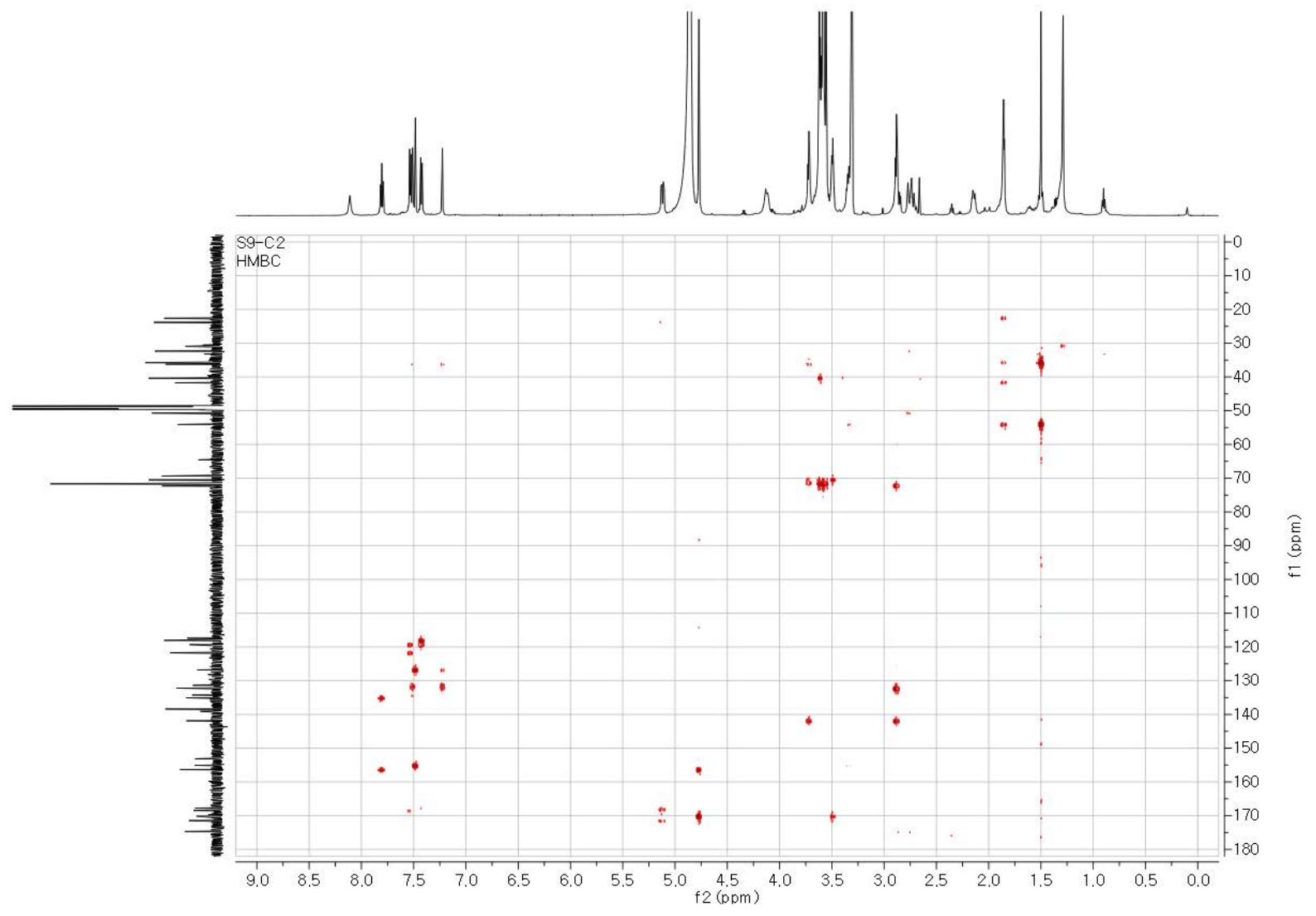

Figure S35. HMBC NMR spectrum of S9-2C in MeOH-d4. 
bioRxiv preprint doi: https://doi.org/10.1101/2021.06.02.446786; this version posted June 2, 2021. The copyright holder for this preprint (which was not certified by peer review) is the author/funder, who has granted bioRxiv a license to display the preprint in perpetuity. It is made available under aCC-BY-NC 4.0 International license.

Table S6. ${ }^{1} \mathrm{H}$ and ${ }^{13} \mathrm{C}$ NMR data of S9-2C in $\mathrm{MeOH}-d_{4}$.

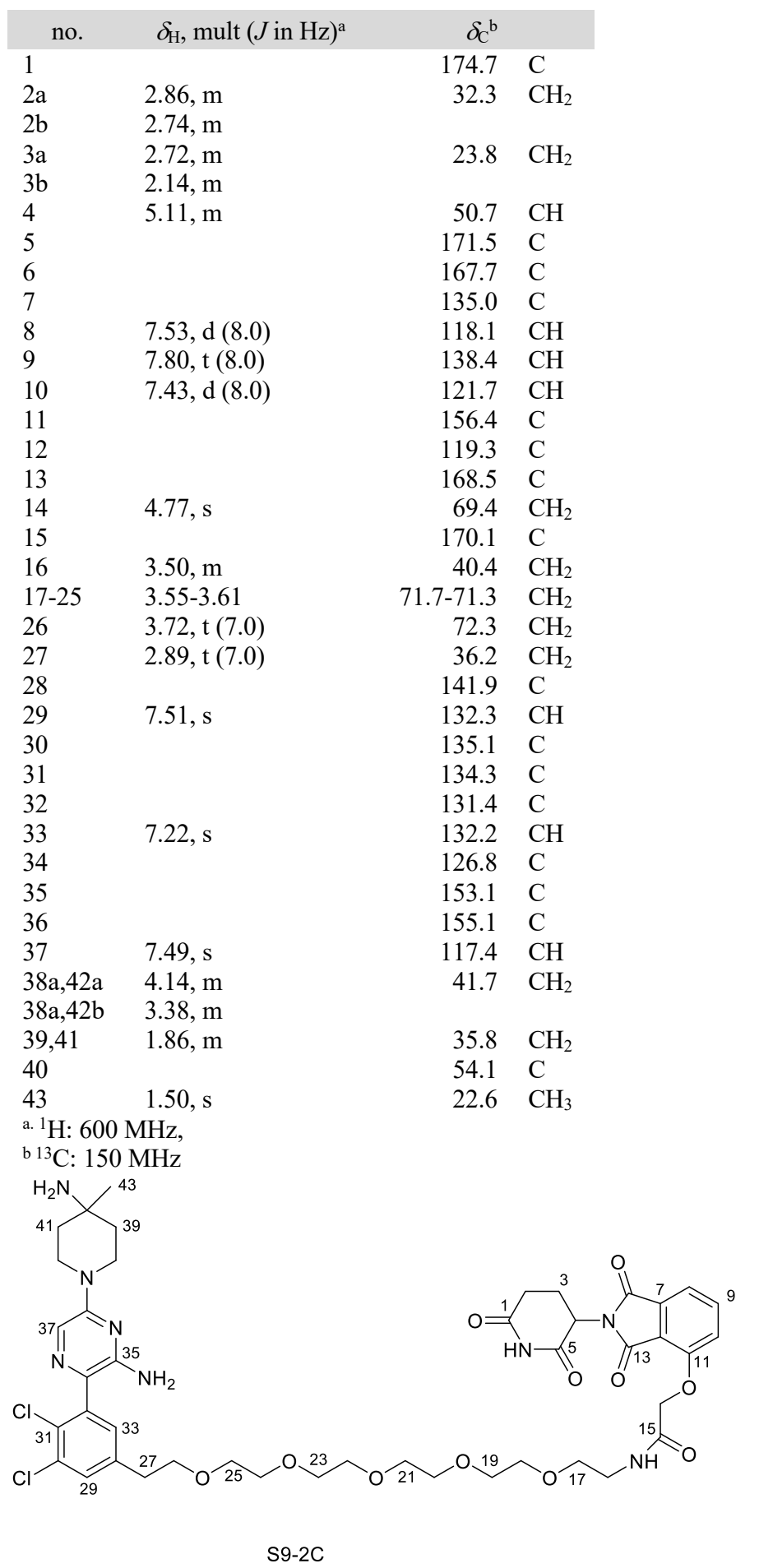


bioRxiv preprint doi: https://doi.org/10.1101/2021.06.02.446786; this version posted June 2, 2021. The copyright holder for this preprint (which was not certified by peer review) is the author/funder, who has granted bioRxiv a license to display the preprint in perpetuity. It is made available under aCC-BY-NC 4.0 International license.

$\mathrm{R} 1-5 \mathrm{C} \_\mathrm{MeOD}$

CAS_Proton MeOD /Optytón stind 2

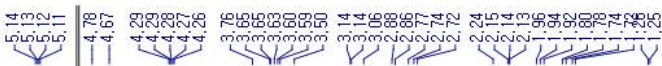

8 .

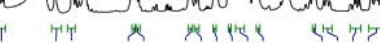

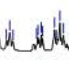

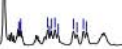

$\stackrel{\bar{c}}{-} \quad$

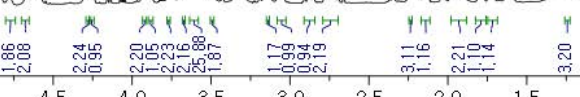

f1 $\stackrel{4.5}{(p m)}$

Figure S36. ${ }^{1} \mathrm{H}$ NMR spectrum of S9-3C in MeOH-d4.
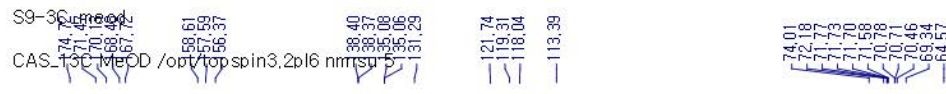

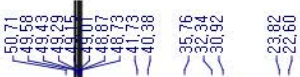

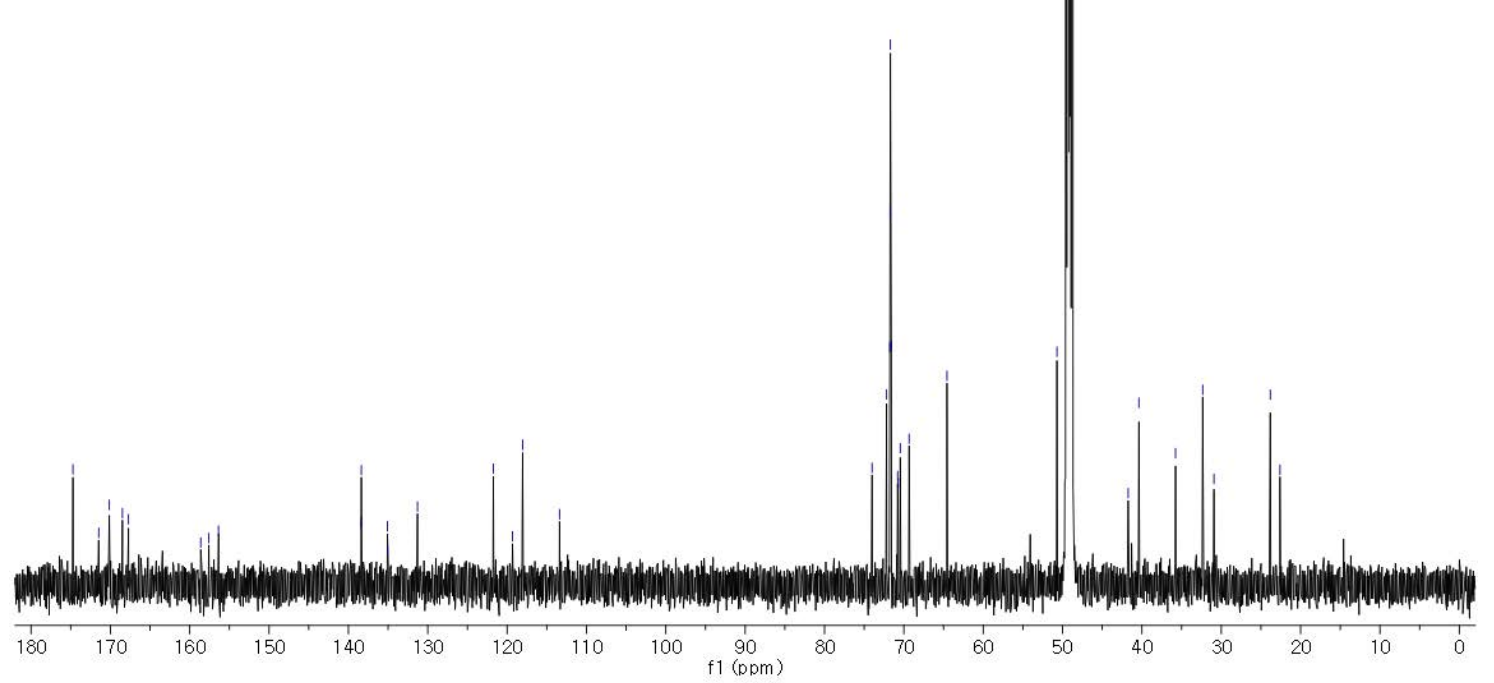

Figure S37. ${ }^{13} \mathrm{C}$ NMR spectrum of S9-3C in MeOH- $d 4$. 
bioRxiv preprint doi: https://doi.org/10.1101/2021.06.02.446786; this version posted June 2, 2021. The copyright holder for this preprint (which was not certified by peer review) is the author/funder, who has granted bioRxiv a license to display the preprint in perpetuity. It is made available under aCC-BY-NC 4.0 International license.

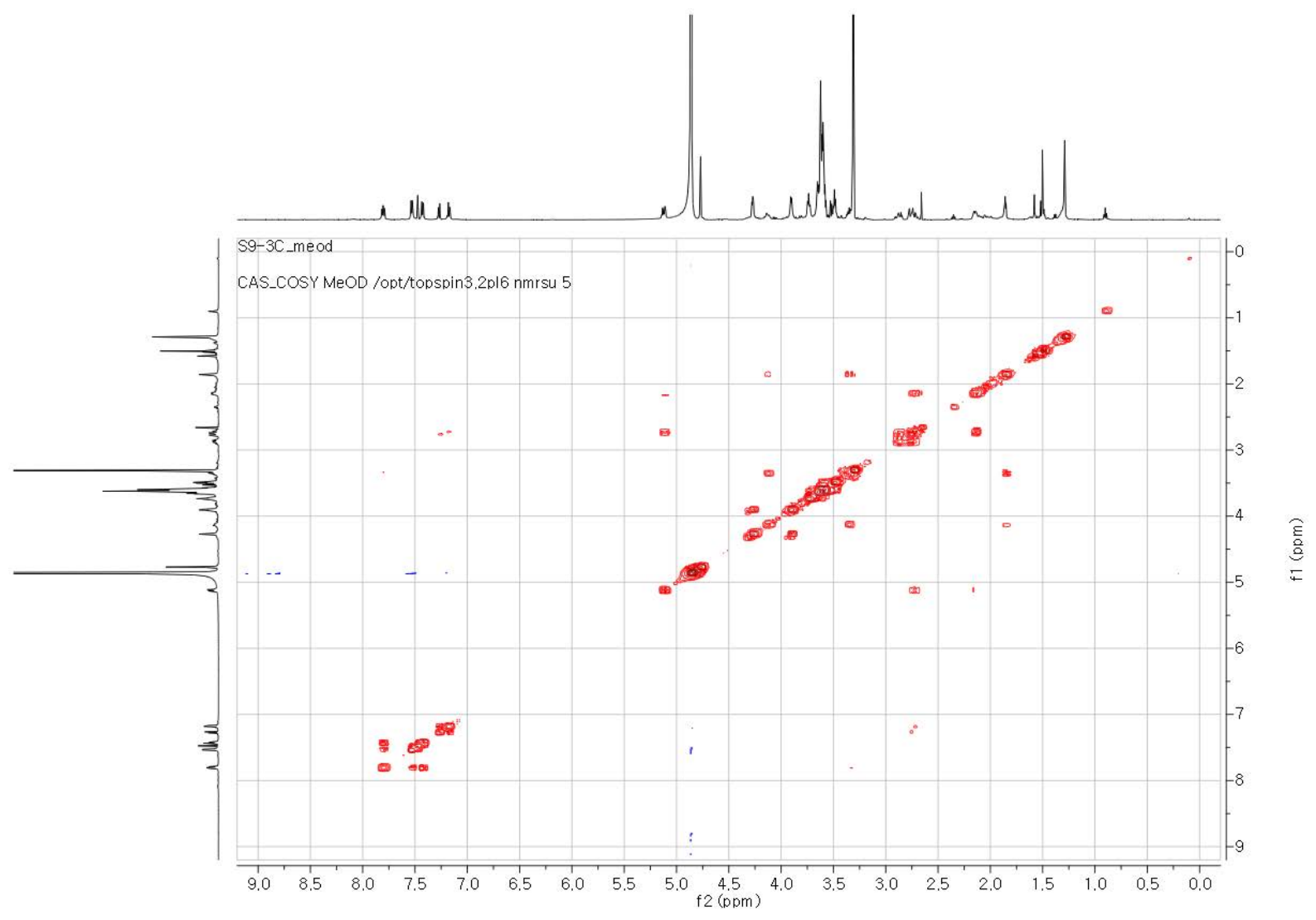

Figure S38. COSY NMR spectrum of S9-3C in MeOH-d4.

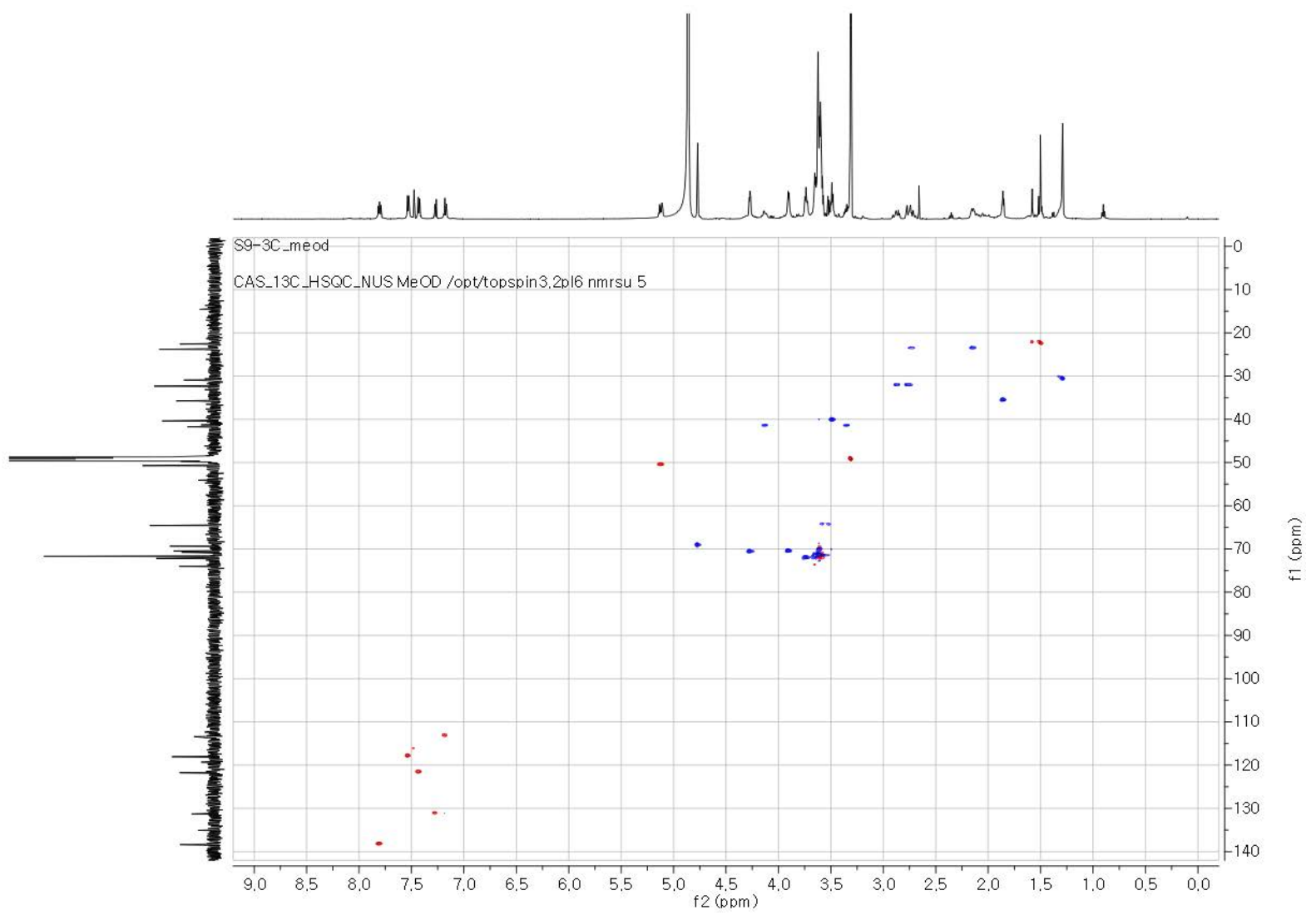

Figure S39. HSQC NMR spectrum of S9-3C in MeOH-d4. 
bioRxiv preprint doi: https://doi.org/10.1101/2021.06.02.446786; this version posted June 2, 2021. The copyright holder for this preprint (which was not certified by peer review) is the author/funder, who has granted bioRxiv a license to display the preprint in perpetuity. It is made available under aCC-BY-NC 4.0 International license.

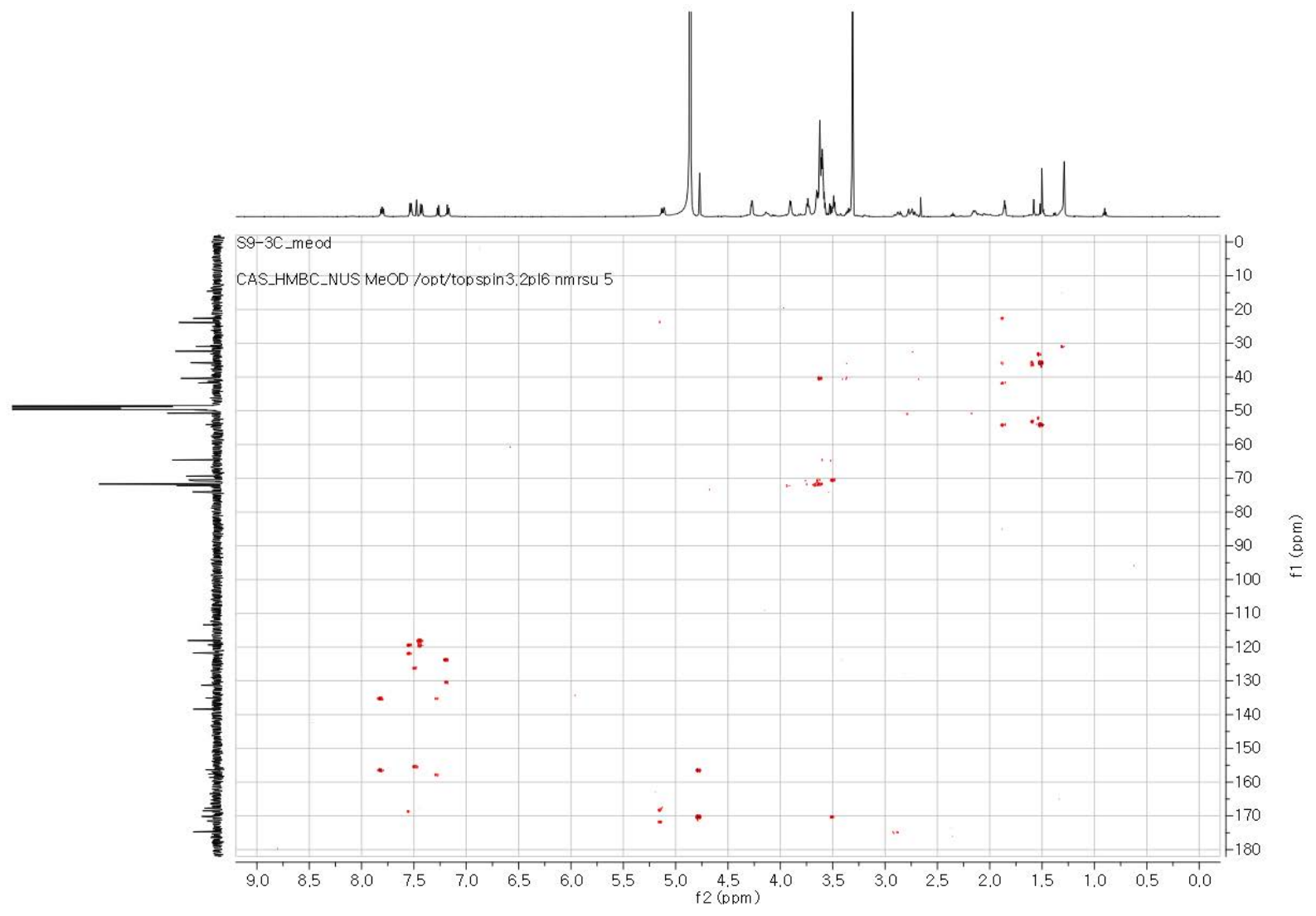

Figure S40. HMBC NMR spectrum of S9-3C in MeOH-d4. 
bioRxiv preprint doi: https://doi.org/10.1101/2021.06.02.446786; this version posted June 2, 2021. The copyright holder for this preprint (which was not certified by peer review) is the author/funder, who has granted bioRxiv a license to display the preprint in perpetuity. It is made available under aCC-BY-NC 4.0 International license.

Table S7. ${ }^{1} \mathrm{H}$ and ${ }^{13} \mathrm{C}$ NMR data of S9-3C in $\mathrm{MeOH}-d_{4}$.

\begin{tabular}{|c|c|c|c|}
\hline no. & $\delta_{\mathrm{H}}$, mult $(J \text { in } \mathrm{Hz})^{\mathrm{a}}$ & $\delta_{\mathrm{C}}^{\mathrm{b}}$ & \\
\hline 1 & & 174.7 & $\mathrm{C}$ \\
\hline $2 \mathrm{a}$ & $2.86, \mathrm{~m}$ & 32.3 & $\mathrm{CH}_{2}$ \\
\hline $2 b$ & $2.74, \mathrm{~m}$ & & \\
\hline $3 a$ & $2.72, \mathrm{~m}$ & 23.8 & $\mathrm{CH}_{2}$ \\
\hline $3 b$ & $2.14, \mathrm{~m}$ & & \\
\hline 4 & $5.11, \mathrm{~m}$ & 50.7 & $\mathrm{CH}$ \\
\hline 5 & & 171.5 & $\mathrm{C}$ \\
\hline 6 & & 167.7 & $\mathrm{C}$ \\
\hline 7 & & 168.5 & $\mathrm{C}$ \\
\hline 8 & & 135.0 & $\mathrm{C}$ \\
\hline 9 & $7.53, \mathrm{~d}(8.0)$ & 118.1 & $\mathrm{CH}$ \\
\hline 10 & $7.80, t(8.0)$ & 138.4 & $\mathrm{CH}$ \\
\hline 11 & $7.43, \mathrm{~d}(8.0)$ & 121.7 & $\mathrm{CH}$ \\
\hline 12 & & 156.4 & $\mathrm{C}$ \\
\hline 13 & & 119.3 & $\mathrm{C}$ \\
\hline 14 & $4.77, \mathrm{~s}$ & 69.4 & $\mathrm{CH}_{2}$ \\
\hline 15 & & 170.1 & $\mathrm{C}$ \\
\hline 16 & $3.50, \mathrm{~m}$ & 40.4 & $\mathrm{CH}_{2}$ \\
\hline $17-25$ & $3.57-3.62$ & $72.2-71.6$ & $\mathrm{CH}_{2}$ \\
\hline 26 & $3.91, \mathrm{~m}$ & 70.7 & $\mathrm{CH}_{2}$ \\
\hline 27 & $4.28, \mathrm{~m}$ & 70.8 & $\mathrm{CH}_{2}$ \\
\hline 28 & & 157.6 & $\mathrm{C}$ \\
\hline 29 & & 123.9 & $\mathrm{C}$ \\
\hline 30 & & 135.1 & $\mathrm{C}$ \\
\hline 31 & & 130.3 & $\mathrm{C}$ \\
\hline 32 & $7.27, \mathrm{~d}(8.0)$ & 131.3 & $\mathrm{CH}$ \\
\hline 33 & $7.17, \mathrm{~d}(8.0)$ & 113.4 & $\mathrm{CH}$ \\
\hline 34 & & 126.4 & $\mathrm{C}$ \\
\hline 35 & & 156.4 & $\mathrm{C}$ \\
\hline 36 & & 158.6 & $\mathrm{C}$ \\
\hline 37 & $7.48, \mathrm{~s}$ & 116.1 & $\mathrm{CH}$ \\
\hline $38 \mathrm{a}, 42 \mathrm{a}$ & $4.13, \mathrm{~m}$ & 41.4 & $\mathrm{CH}_{2}$ \\
\hline $38 b, 42 b$ & $3.35, \mathrm{~m}$ & & \\
\hline 39,41 & $1.86, \mathrm{~m}$ & 35.8 & $\mathrm{CH}_{2}$ \\
\hline 40 & & 54.1 & $\mathrm{C}$ \\
\hline 43 & $1.50, \mathrm{~s}$ & 22.6 & $\mathrm{CH}_{3}$ \\
\hline $\begin{array}{l}{ }^{\text {a. }} \mathrm{H}: 60 \\
\text { b }{ }^{13} \mathrm{C}: 15\end{array}$ & $\begin{array}{l}\text { MHz, } \\
\mathrm{MHz}\end{array}$ & & \\
\hline
\end{tabular}

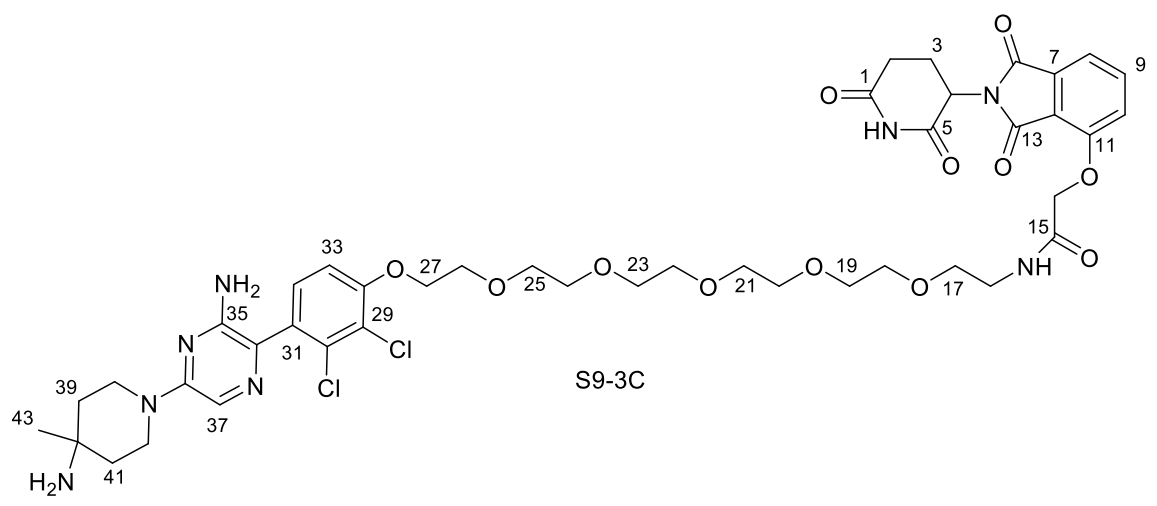


bioRxiv preprint doi: https://doi.org/10.1101/2021.06.02.446786; this version posted June 2, 2021. The copyright holder for this preprint (which was not certified by peer review) is the author/funder, who has granted bioRxiv a license to display the preprint in perpetuity. It is made available under aCC-BY-NC 4.0 International license.

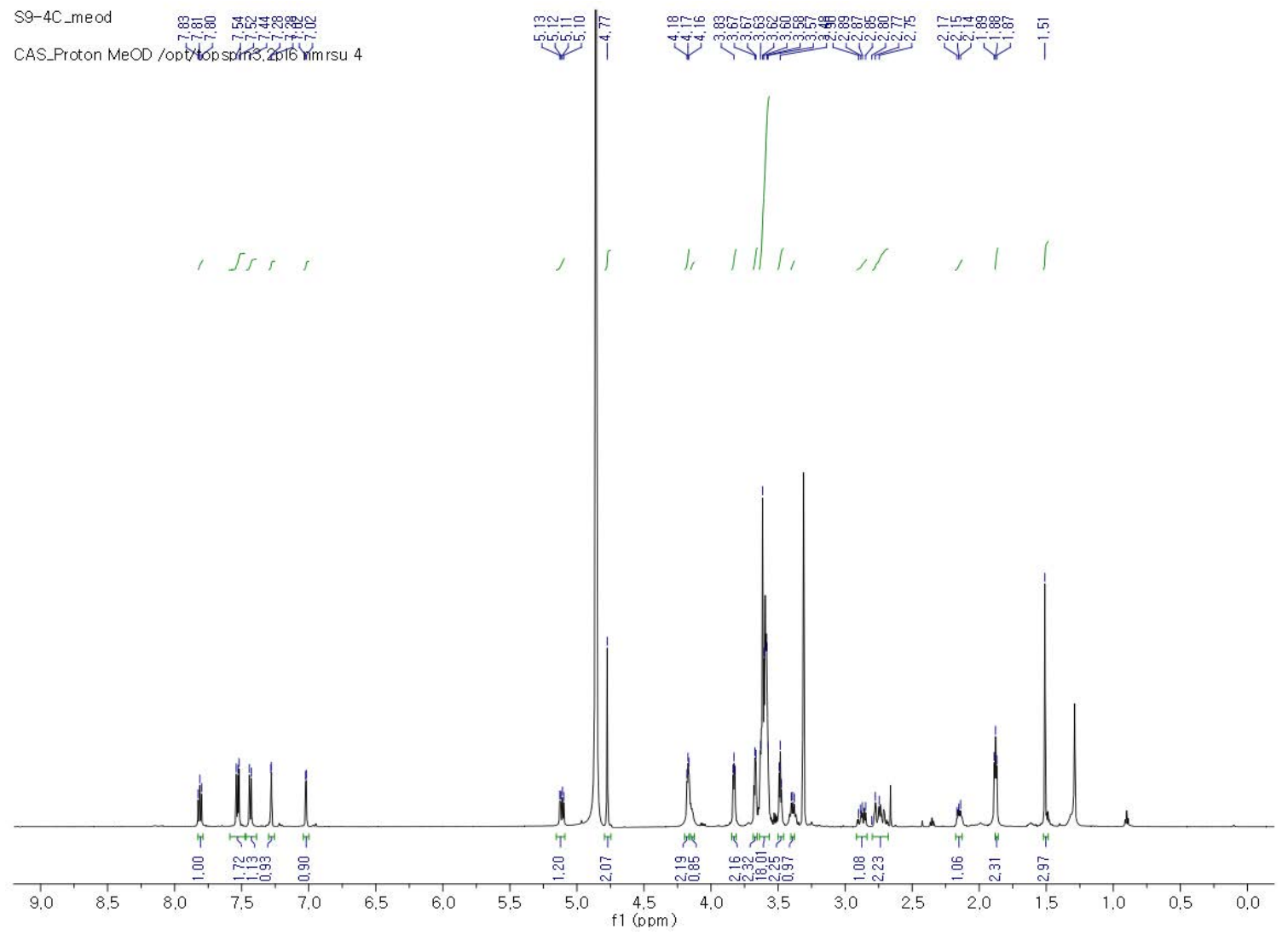

Figure S41. ${ }^{1} \mathrm{H}$ NMR spectrum of S9-4C in MeOH- $d 4$.
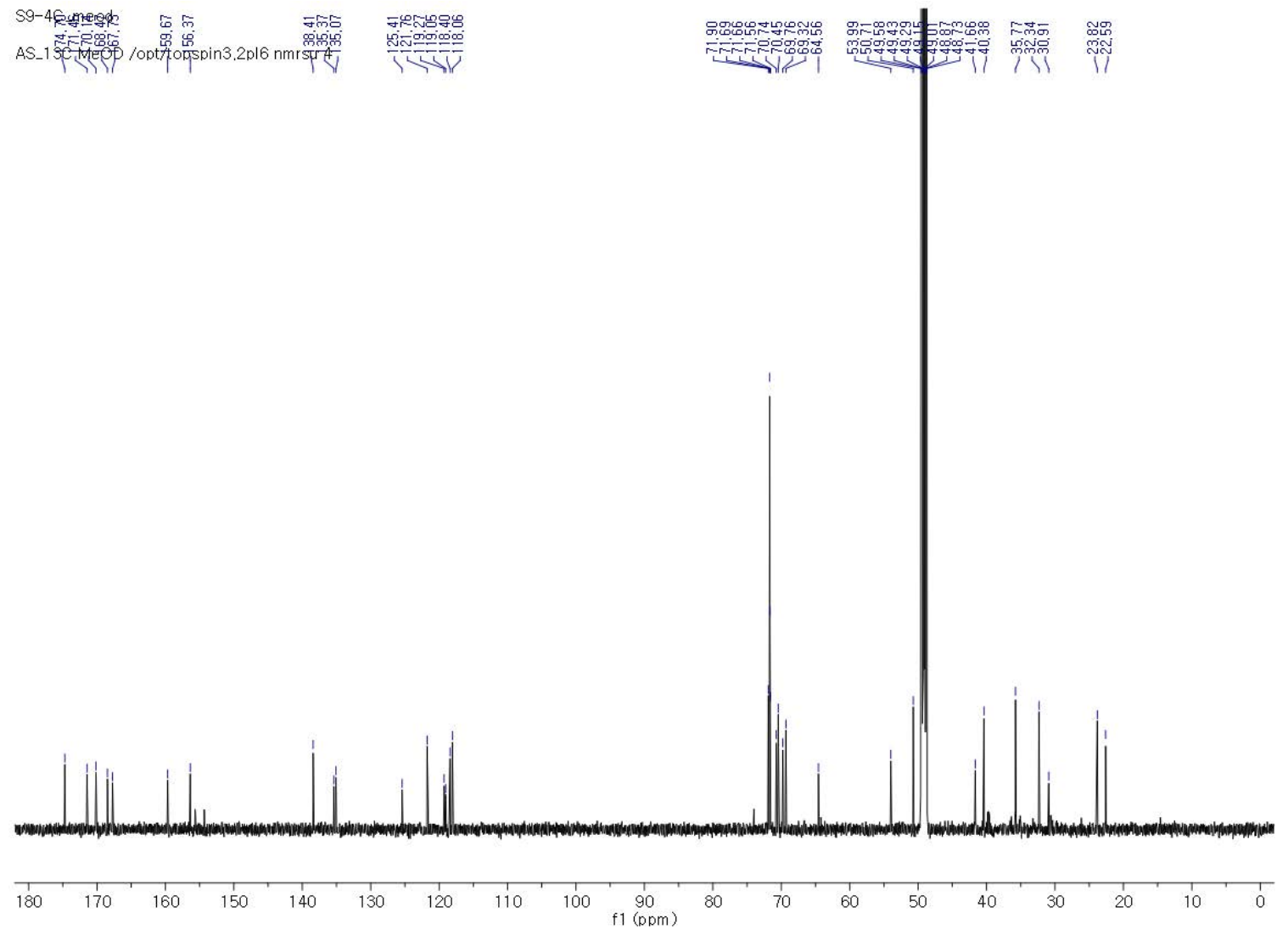

Figure S42. ${ }^{13} \mathrm{C}$ NMR spectrum of S9-4C in MeOH- $d_{4}$. 
bioRxiv preprint doi: https://doi.org/10.1101/2021.06.02.446786; this version posted June 2, 2021. The copyright holder for this preprint (which was not certified by peer review) is the author/funder, who has granted bioRxiv a license to display the preprint in perpetuity. It is made available under aCC-BY-NC 4.0 International license.

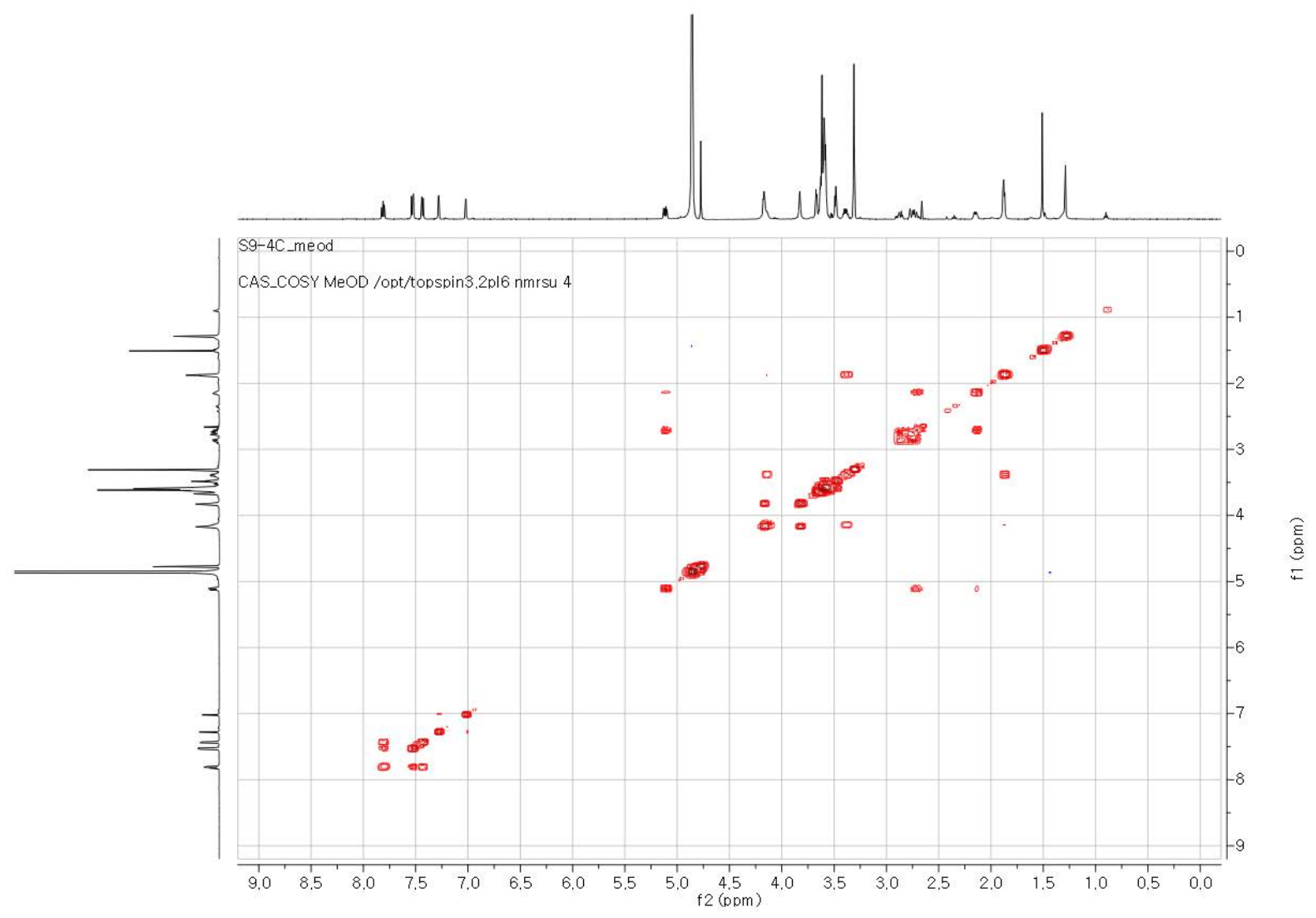

Figure S43. COSY NMR spectrum of S9-4C in MeOH-d4.

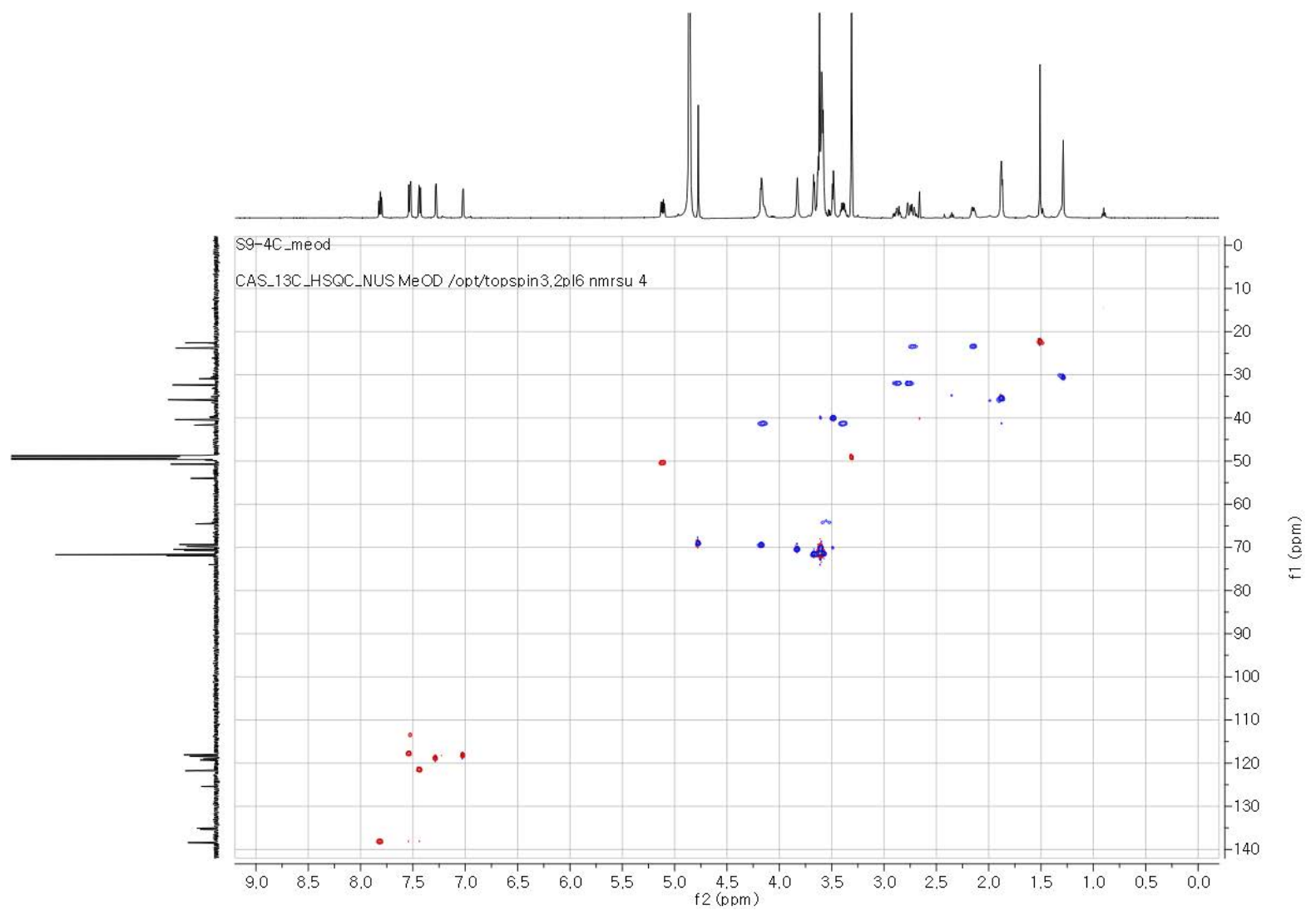

Figure S44. HSQC NMR spectrum of S9-4C in MeOH- $d_{4}$. 
bioRxiv preprint doi: https://doi.org/10.1101/2021.06.02.446786; this version posted June 2, 2021. The copyright holder for this preprint (which was not certified by peer review) is the author/funder, who has granted bioRxiv a license to display the preprint in perpetuity. It is made available under aCC-BY-NC 4.0 International license.

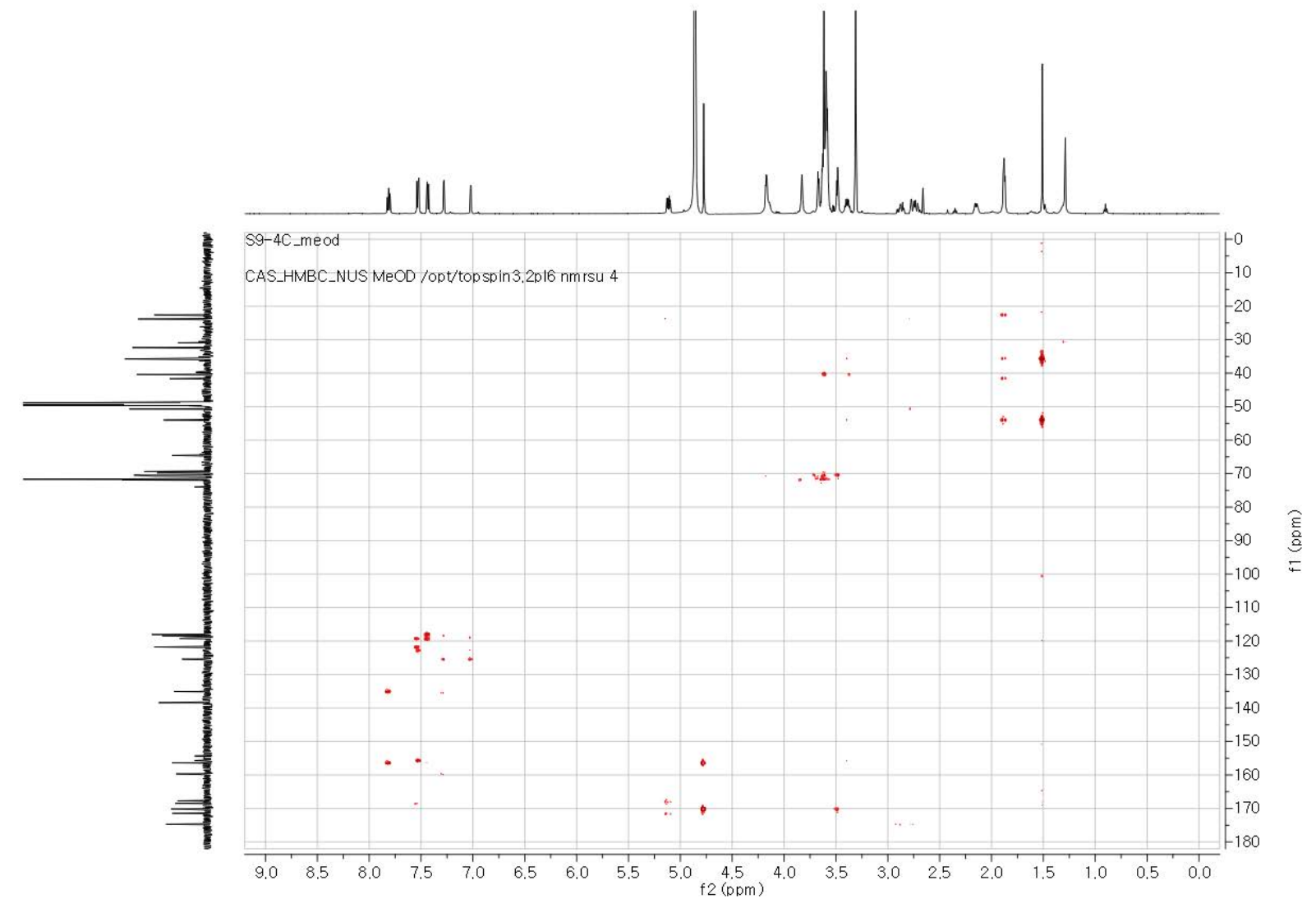

Figure S45. HMBC NMR spectrum of S9-4C in MeOH-d4. 
bioRxiv preprint doi: https://doi.org/10.1101/2021.06.02.446786; this version posted June 2, 2021. The copyright holder for this preprint (which was not certified by peer review) is the author/funder, who has granted bioRxiv a license to display the preprint in perpetuity. It is made available under aCC-BY-NC 4.0 International license.

Table S8. ${ }^{1} \mathrm{H}$ and ${ }^{13} \mathrm{C}$ NMR data of S9-4C in $\mathrm{MeOH}-d_{4}$.

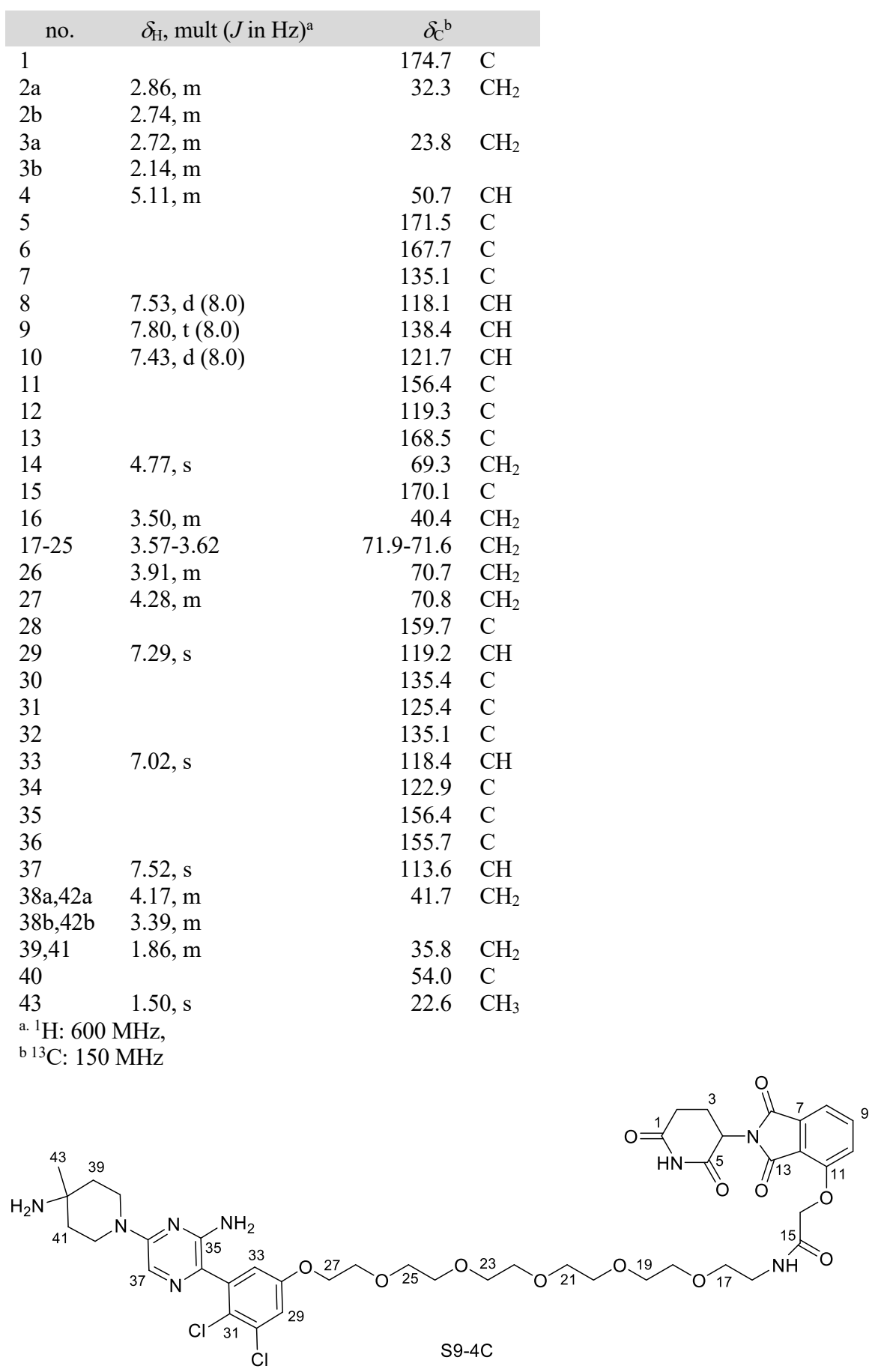


bioRxiv preprint doi: https://doi.org/10.1101/2021.06.02.446786; this version posted June 2, 2021. The copyright holder for this preprint (which was not certified by peer review) is the author/funder, who has granted bioRxiv a license to display the preprint in perpetuity. It is made available under aCC-BY-NC 4.0 International license.

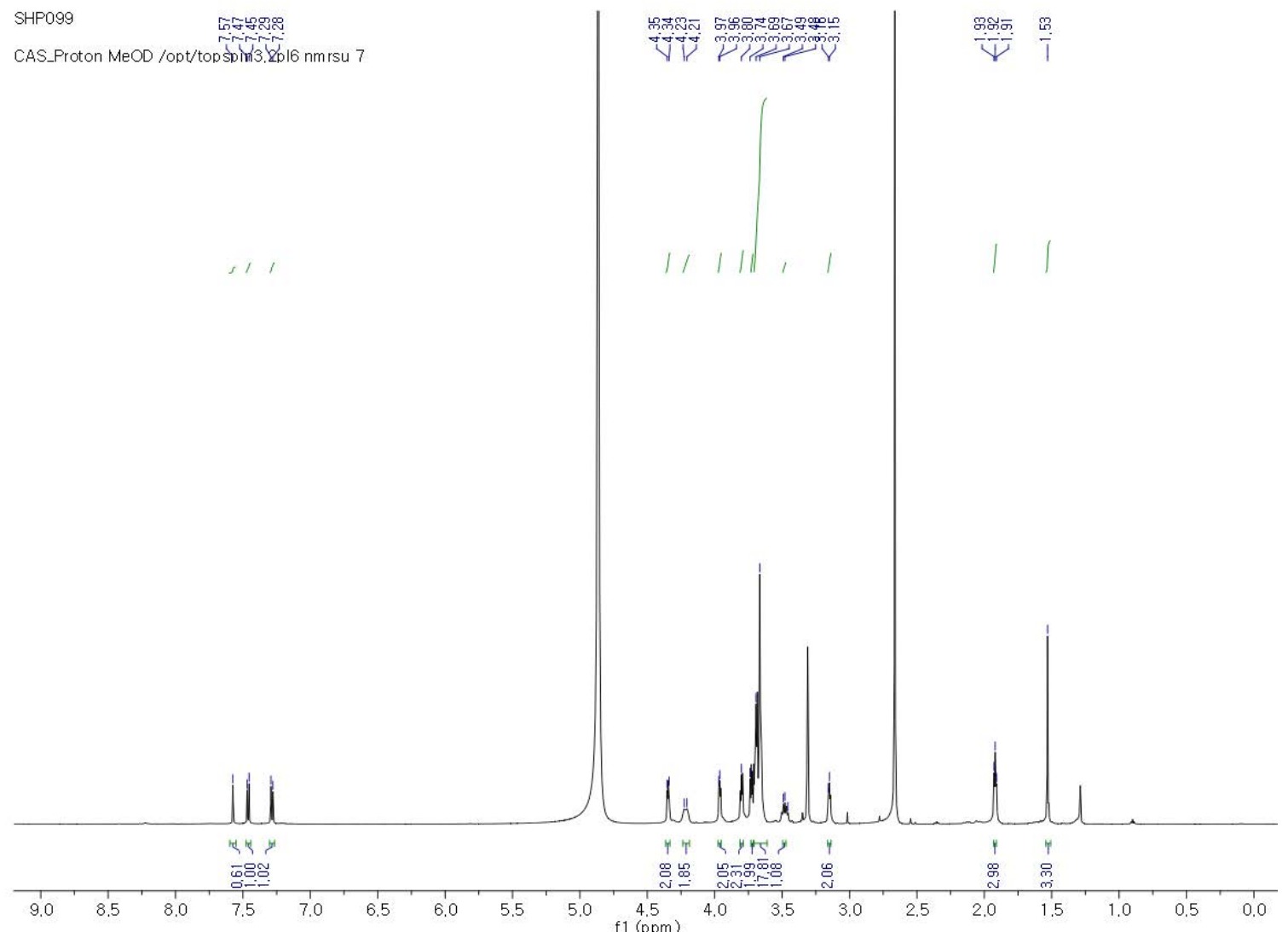

Figure S46. ${ }^{1} \mathrm{H}$ NMR spectrum of SHP099-I34 in MeOH-d4.

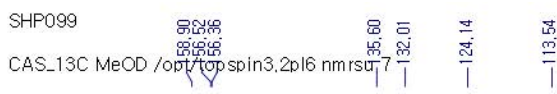
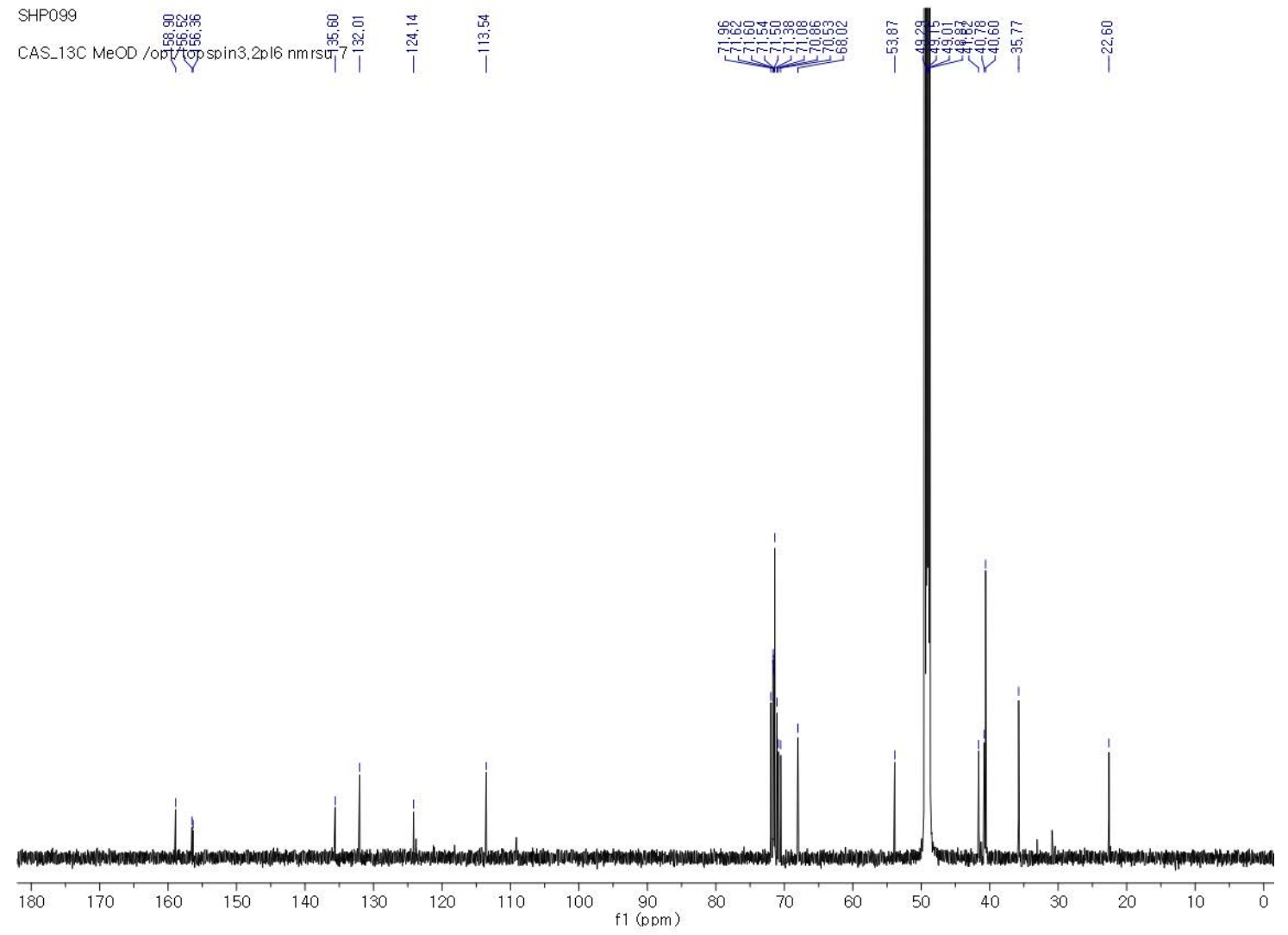

Figure S47. ${ }^{13} \mathrm{C}$ NMR spectrum of SHP099-I34 in MeOH-d $d_{4}$ 
bioRxiv preprint doi: https://doi.org/10.1101/2021.06.02.446786; this version posted June 2, 2021. The copyright holder for this preprint (which was not certified by peer review) is the author/funder, who has granted bioRxiv a license to display the preprint in perpetuity. It is made available under aCC-BY-NC 4.0 International license.

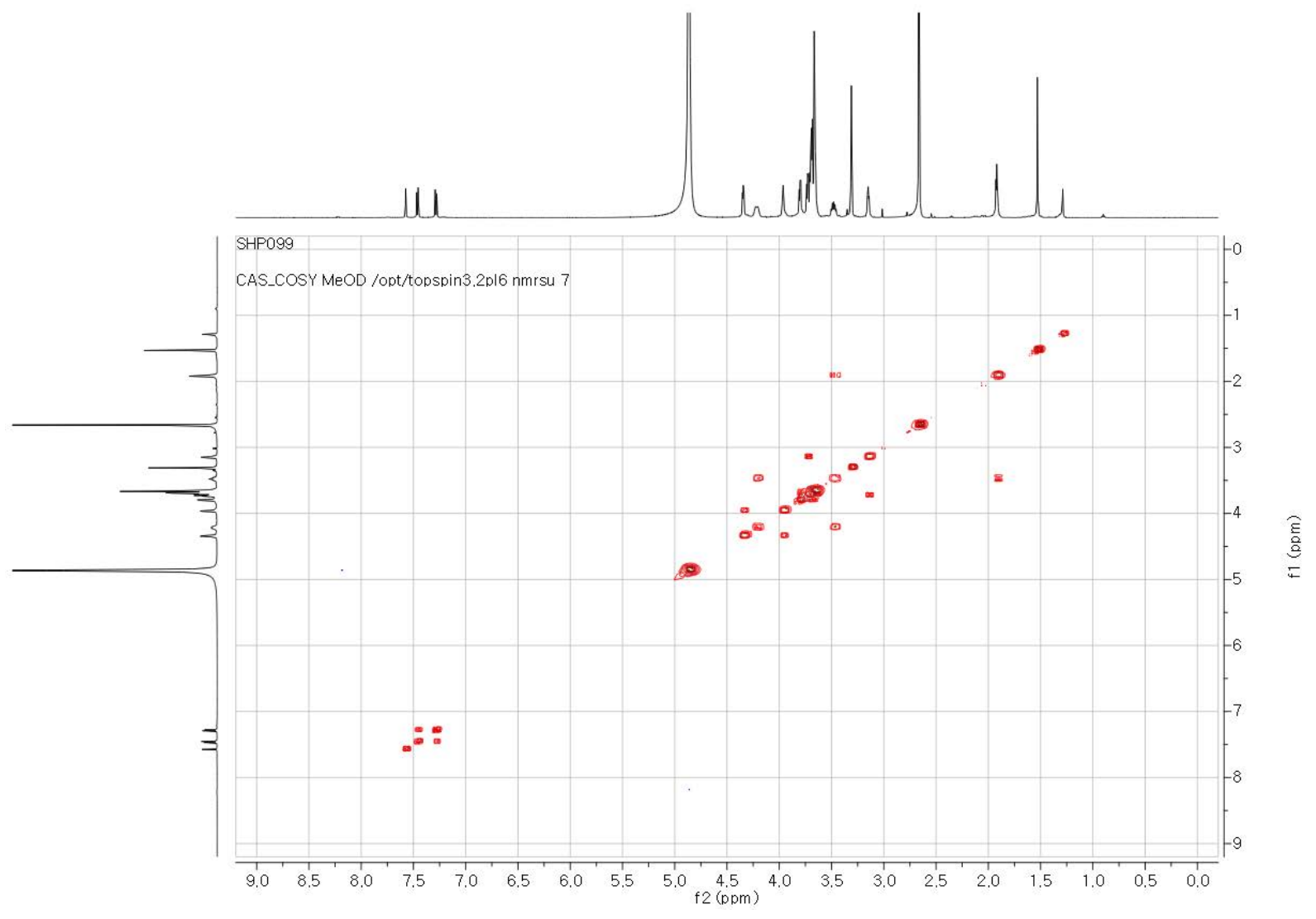

Figure S48. COSY NMR spectrum of SHP099-I34 in MeOH- $d 4$.

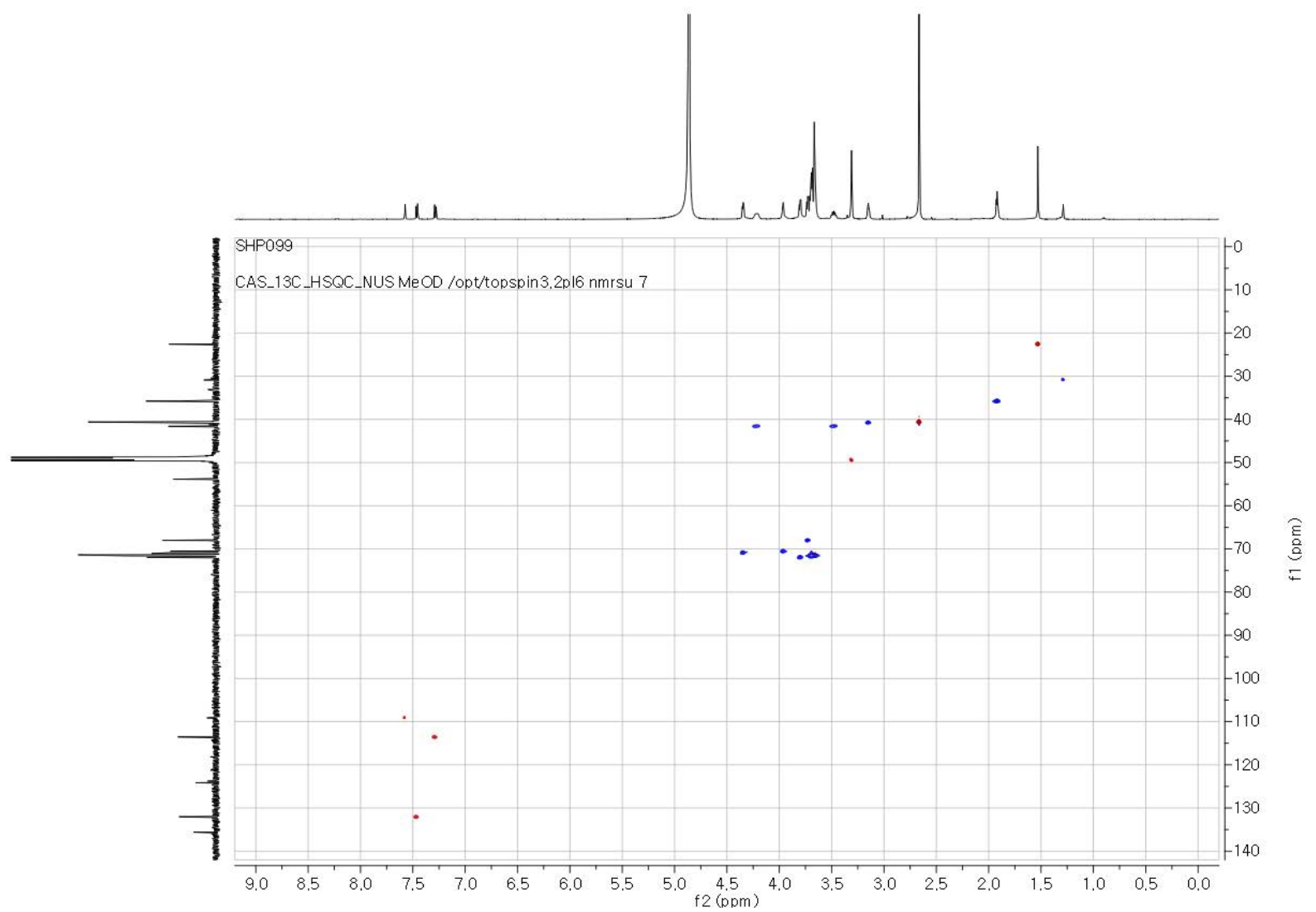

Figure S49. HSQC NMR spectrum of SHP099-I34 in MeOH- $d_{4}$. 
bioRxiv preprint doi: https://doi.org/10.1101/2021.06.02.446786; this version posted June 2, 2021. The copyright holder for this preprint (which was not certified by peer review) is the author/funder, who has granted bioRxiv a license to display the preprint in perpetuity. It is made available under aCC-BY-NC 4.0 International license.

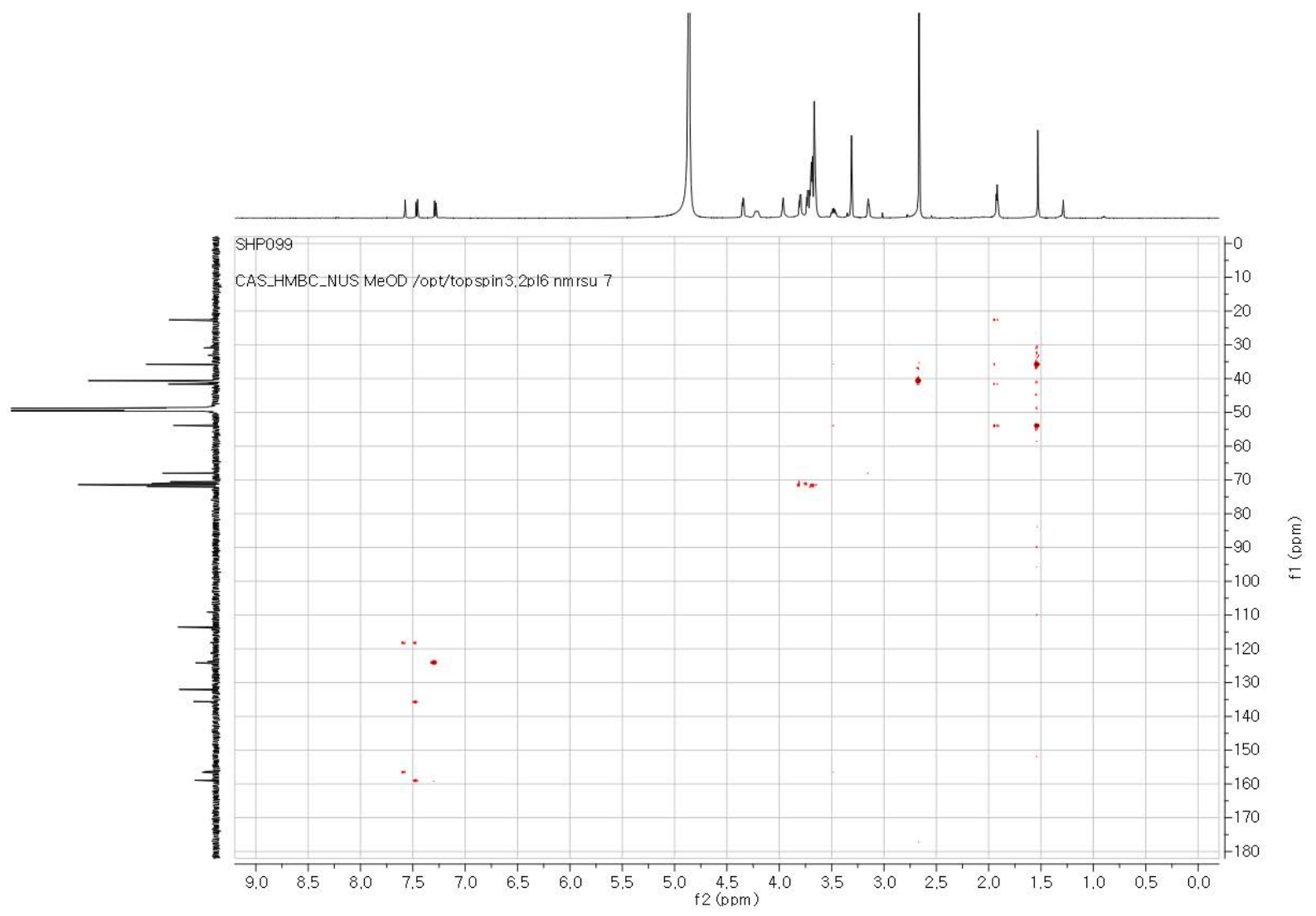

Figure S50. HMBC NMR spectrum of SHP099-I34 in MeOH- $d 4$. 
bioRxiv preprint doi: https://doi.org/10.1101/2021.06.02.446786; this version posted June 2, 2021. The copyright holder for this preprint (which was not certified by peer review) is the author/funder, who has granted bioRxiv a license to display the preprint in perpetuity. It is made available under aCC-BY-NC 4.0 International license.

Table S9. ${ }^{1} \mathrm{H}$ and ${ }^{13} \mathrm{C}$ NMR data of SHP099-I34 in MeOH- $d_{4}$.

\begin{tabular}{llrl}
\multicolumn{1}{r}{ no. } & $\delta_{\mathrm{H}}$, mult $(J \text { in } \mathrm{Hz})^{\mathrm{a}}$ & $\delta_{\mathrm{C}}^{\mathrm{b}}$ & \\
1 & $3.15, \mathrm{t}(6.0)$ & 40.8 & $\mathrm{CH}_{2}$ \\
$2-10$ & $3.72-3.65, \mathrm{~m}$ & $72.0-70.5$ & $\mathrm{CH}_{2}$ \\
11 & $3.96, \mathrm{~m}$ & 70.5 & $\mathrm{CH}_{2}$ \\
12 & $4.35, \mathrm{~m}$ & 70.8 & $\mathrm{CH}_{2}$ \\
13 & & 158.9 & $\mathrm{C}$ \\
14 & & 123.9 & $\mathrm{C}$ \\
15 & & 135.6 & $\mathrm{C}$ \\
16 & & 124.2 & $\mathrm{C}$ \\
17 & $7.46, \mathrm{~d}(8.0)$ & 132.0 & $\mathrm{CH}$ \\
18 & $7.28, \mathrm{~d}(8.0)$ & 113.5 & $\mathrm{CH}$ \\
19 & & 118.4 & $\mathrm{C}$ \\
20 & & 156.4 & $\mathrm{C}$ \\
21 & & 156.5 & $\mathrm{C}$ \\
22 & $7.57, \mathrm{~s}$ & 109.1 & $\mathrm{CH}$ \\
$23 \mathrm{a}, 28 \mathrm{a}$ & $4.23, \mathrm{~m}$ & 41.6 & $\mathrm{CH}_{2}$ \\
$23 \mathrm{~b}, 28 \mathrm{~b}$ & $3.48, \mathrm{~m}$ & & \\
24,27 & $1.92, \mathrm{t}(5.0)$ & 35.8 & $\mathrm{CH}_{2}$ \\
25 & & 53.9 & $\mathrm{C}$ \\
26 & $1.53, \mathrm{~s}$ & 22.6 & $\mathrm{CH}_{3}$
\end{tabular}

a. ${ }^{1} \mathrm{H}: 600 \mathrm{MHz}$,

${ }^{b}{ }^{13} \mathrm{C}: 150 \mathrm{MHz}$

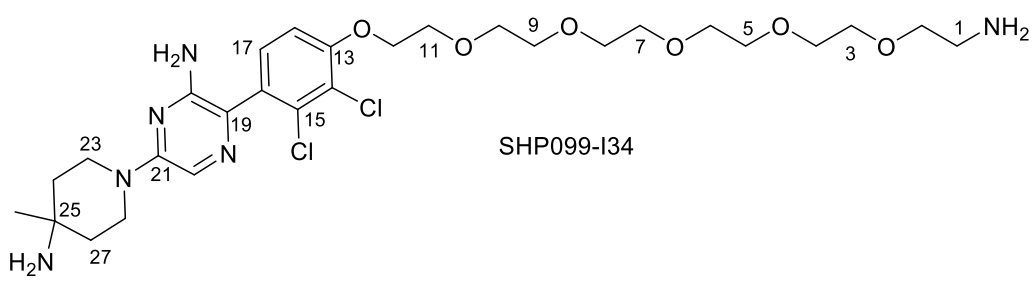


bioRxiv preprint doi: https://doi.org/10.1101/2021.06.02.446786; this version posted June 2, 2021. The copyright holder for this preprint (which was not certified by peer review) is the author/funder, who has granted bioRxiv a license to display the preprint in perpetuity. It is made available under aCC-BY-NC 4.0 International license. 
Table S10: Expected and observed masses of PROTAC compounds.

\begin{tabular}{|c|c|c|c|c|}
\hline Compound & $M$ & {$[\mathrm{M}+\mathrm{H}]+$} & {$[\mathrm{M}+2 \mathrm{H}] 2+$} & \\
\hline \multirow[t]{3}{*}{ SHP099-I34 } & 630.2699 & 631.277177 & 316.142227 & theoretical \\
\hline & & 631.2808 & 316.1446 & observed \\
\hline & & -5.7399509 & -7.5076969 & ppm \\
\hline \multirow[t]{3}{*}{ S9-1C } & 928.32891 & 929.336187 & & theoretical \\
\hline & & 929.3343 & & observed \\
\hline & & 2.02994355 & & ppm \\
\hline \multirow[t]{3}{*}{ S9-2C } & 928.32891 & 929.336187 & & theoretical \\
\hline & & 929.3354 & & observed \\
\hline & & 0.846303 & & ppm \\
\hline \multirow[t]{3}{*}{ S9-3C } & 944.32382 & 945.331097 & & theoretical \\
\hline & & 945.3299 & & observed \\
\hline & & 1.26569411 & & ppm \\
\hline \multirow[t]{3}{*}{ S9-4C } & 944.32382 & 945.331097 & & theoretical \\
\hline & & 945.3311 & & observed \\
\hline & & -0.0037024 & & $\mathrm{ppm}$ \\
\hline \multirow[t]{3}{*}{ R1-1C } & 941.31293 & 942.320207 & & theoretical \\
\hline & & 942.3201 & & observed \\
\hline & & 0.11301891 & & ppm \\
\hline \multirow[t]{3}{*}{ R1-3C } & 1029.36536 & 1030.37264 & & theoretical \\
\hline & & 1030.3721 & & observed \\
\hline & & 0.52068541 & & ppm \\
\hline \multirow[t]{3}{*}{ R1-5C } & 1117.41778 & 1118.42506 & & theoretical \\
\hline & & 1118.4246 & & observed \\
\hline & & 0.40816324 & & ppm \\
\hline
\end{tabular}


bioRxiv preprint doi: https://doi.org/10.1101/2021.06.02.446786; this version posted June 2, 2021. The copyright holder for this preprint (which was not certified by peer review) is the author/funder, who has granted bioRxiv a license to display the preprint in perpetuity. It is made available under aCC-BY-NC 4.0 International license.

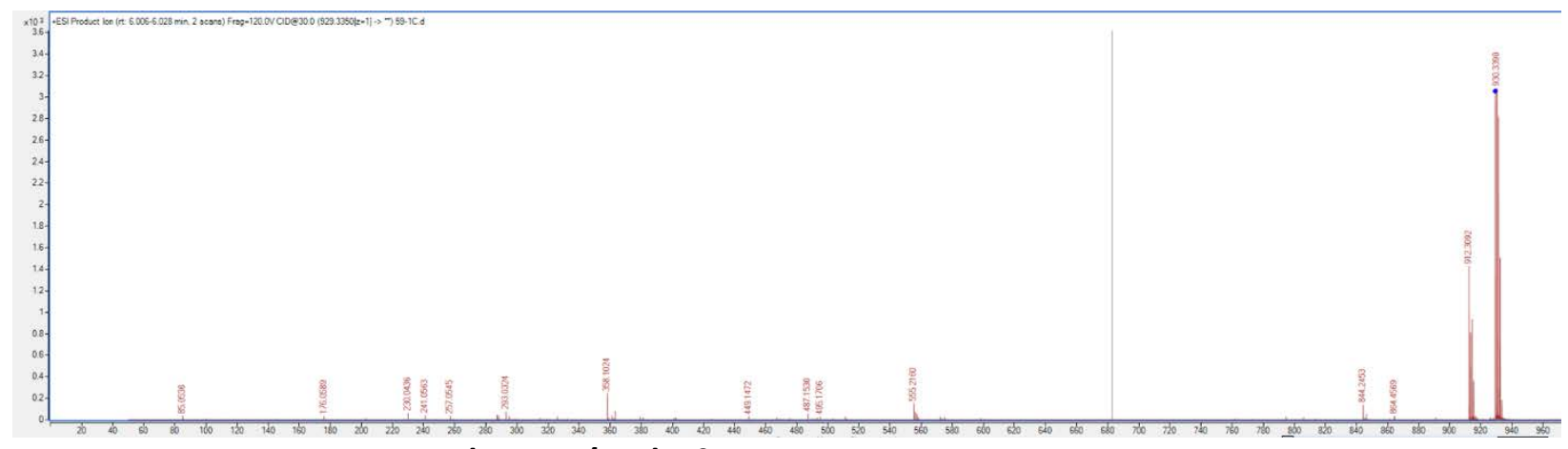

Figure S51: Mass Spectrum (LC-MS/MS) of S9-1C.

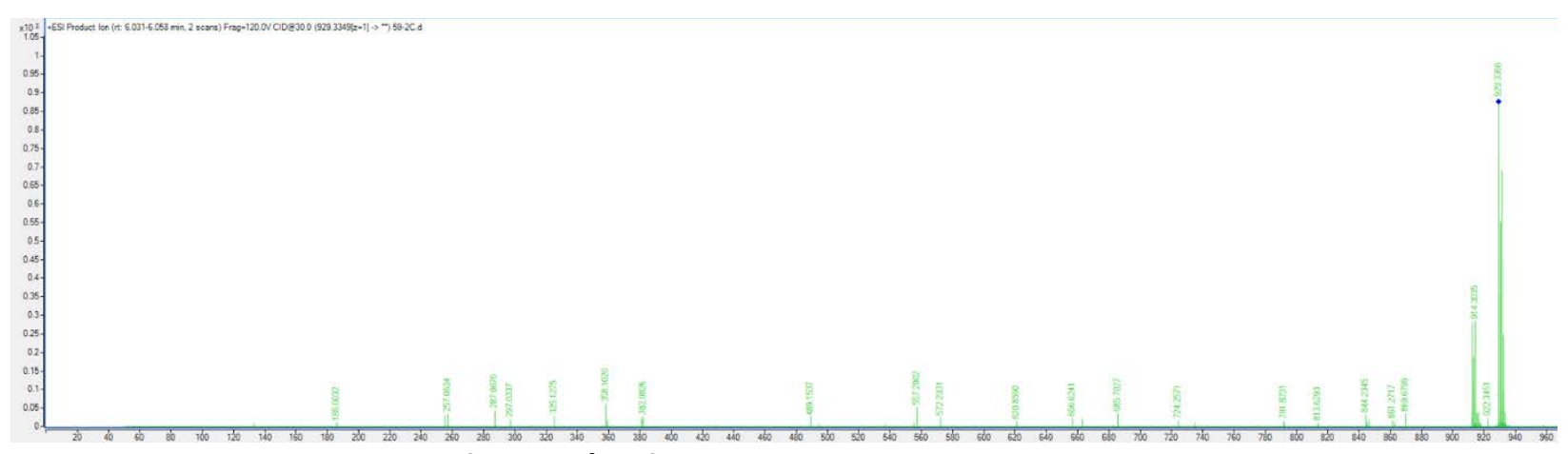

Figure S52: Mass Spectrum (LC-MS/MS) of S9-2C.

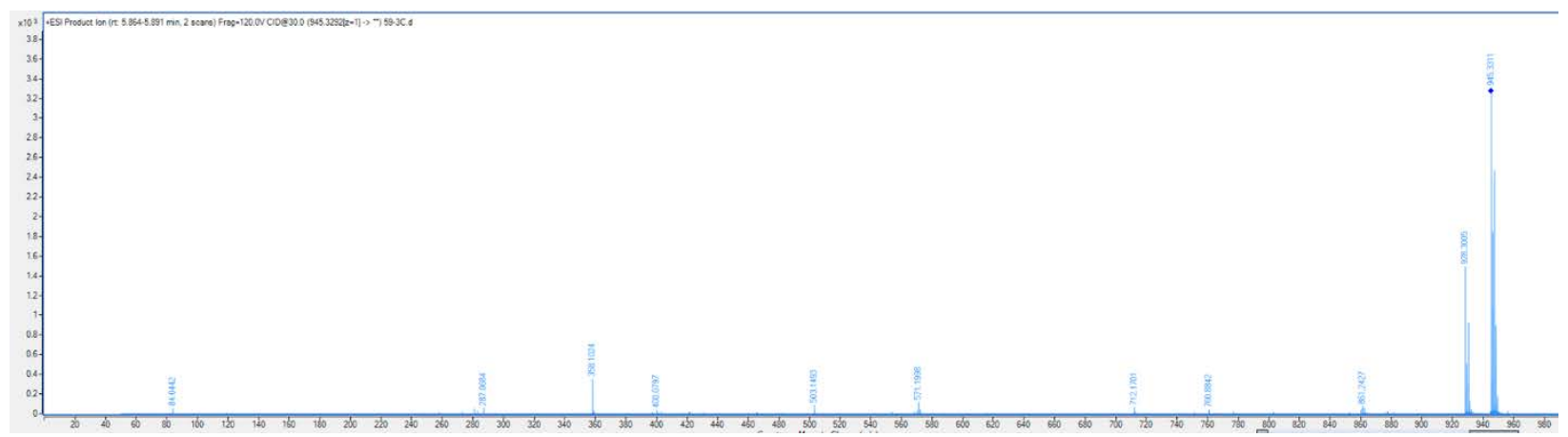

Figure S53: Mass Spectrum (LC-MS/MS) of S9-3C.

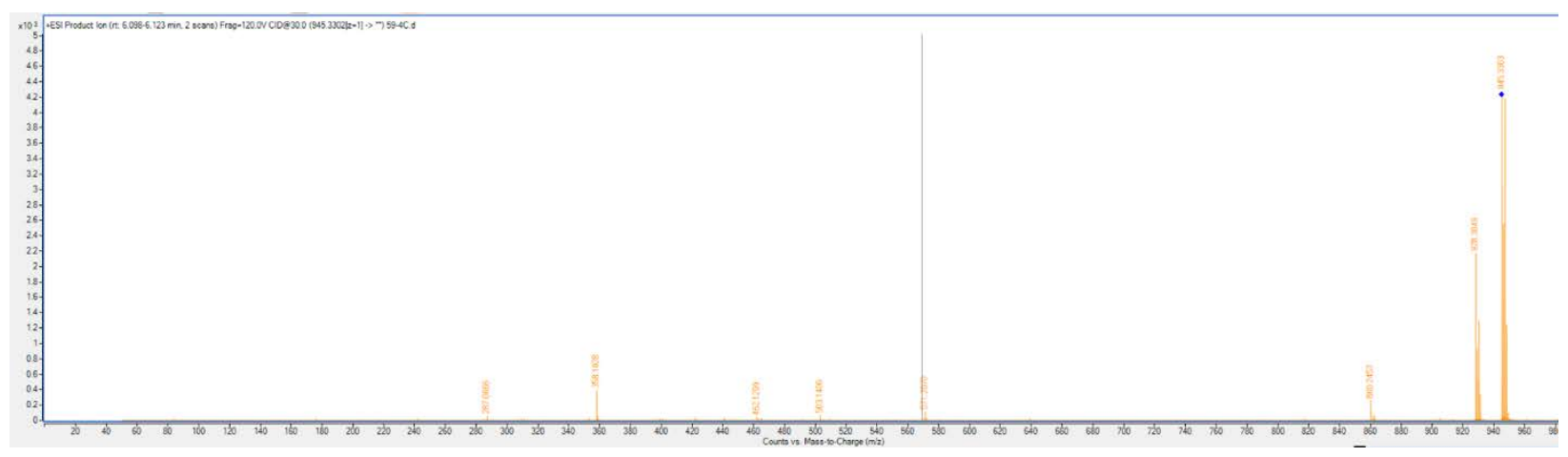

Figure S54: Mass Spectrum (LC-MS/MS) of S9-4C. 
bioRxiv preprint doi: https://doi.org/10.1101/2021.06.02.446786; this version posted June 2, 2021. The copyright holder for this preprint (which

was not certified by peer review) is the author/funder, who has granted bioRxiv a license to display the preprint in perpetuity. It is made available under aCC-BY-NC 4.0 International license.

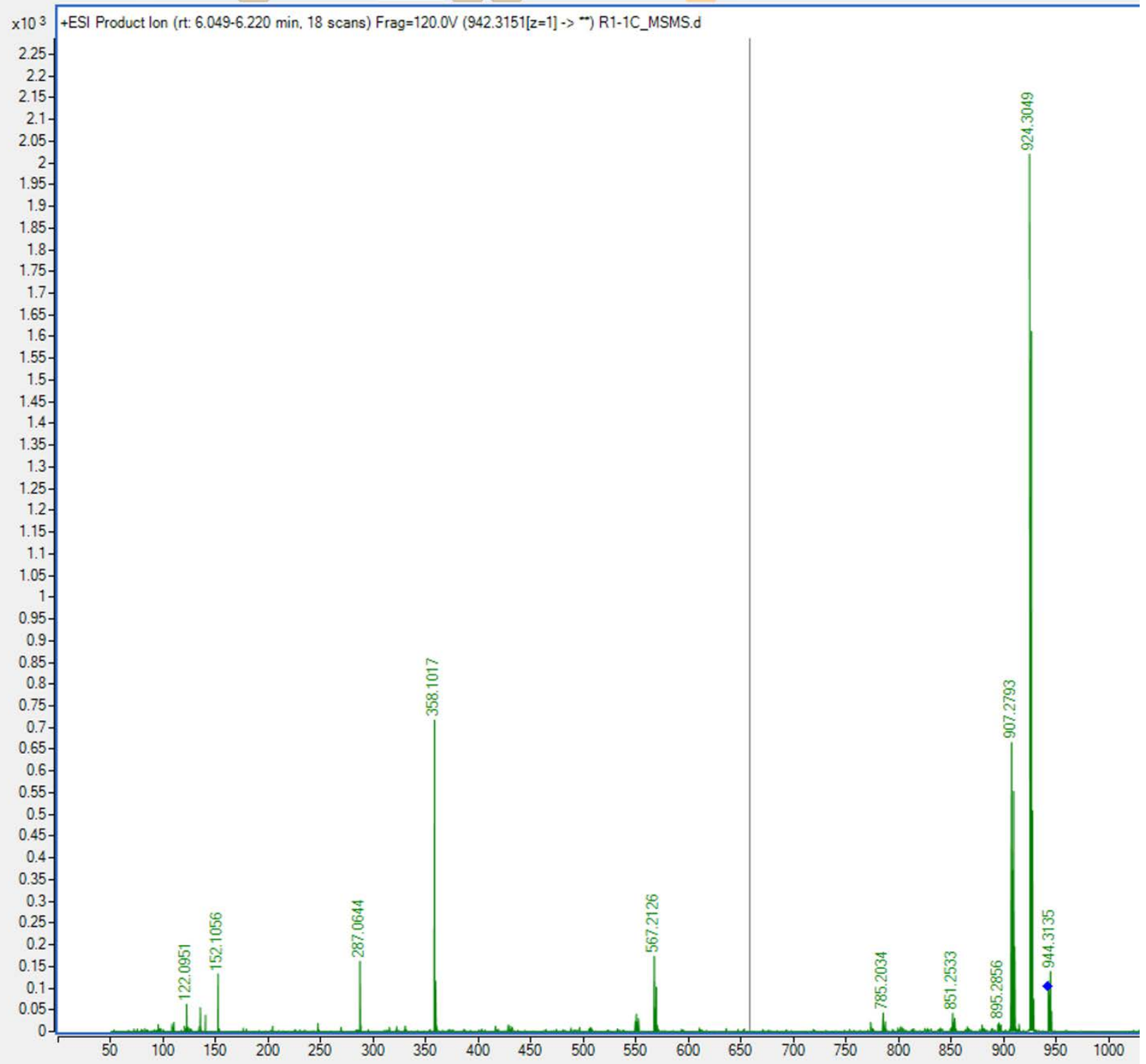

Figure S55: Mass Spectrum (LC-MS/MS) of R1-1C. 
bioRxiv preprint doi: https://doi.org/10.1101/2021.06.02.446786; this version posted June 2, 2021. The copyright holder for this preprint (which was not certified by peer review) is the author/funder, who has granted bioRxiv a license to display the preprint in perpetuity. It is made available under aCC-BY-NC 4.0 International license.

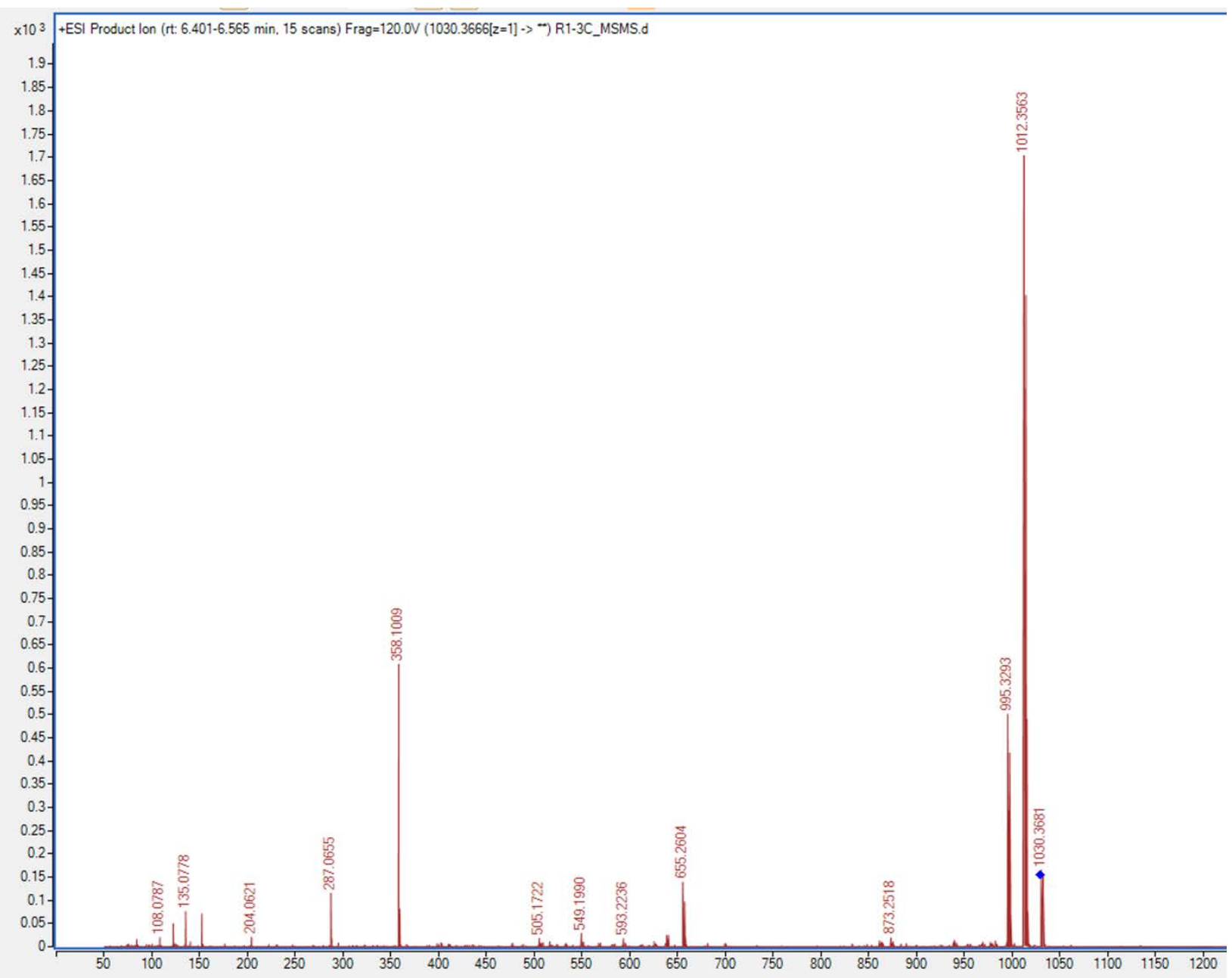

Figure S56: Mass Spectrum (LC-MS/MS) of R1-3C. 
bioRxiv preprint doi: https://doi.org/10.1101/2021.06.02.446786; this version posted June 2, 2021. The copyright holder for this preprint (which was not certified by peer review) is the author/funder, who has granted bioRxiv a license to display the preprint in perpetuity. It is made available under aCC-BY-NC 4.0 International license.

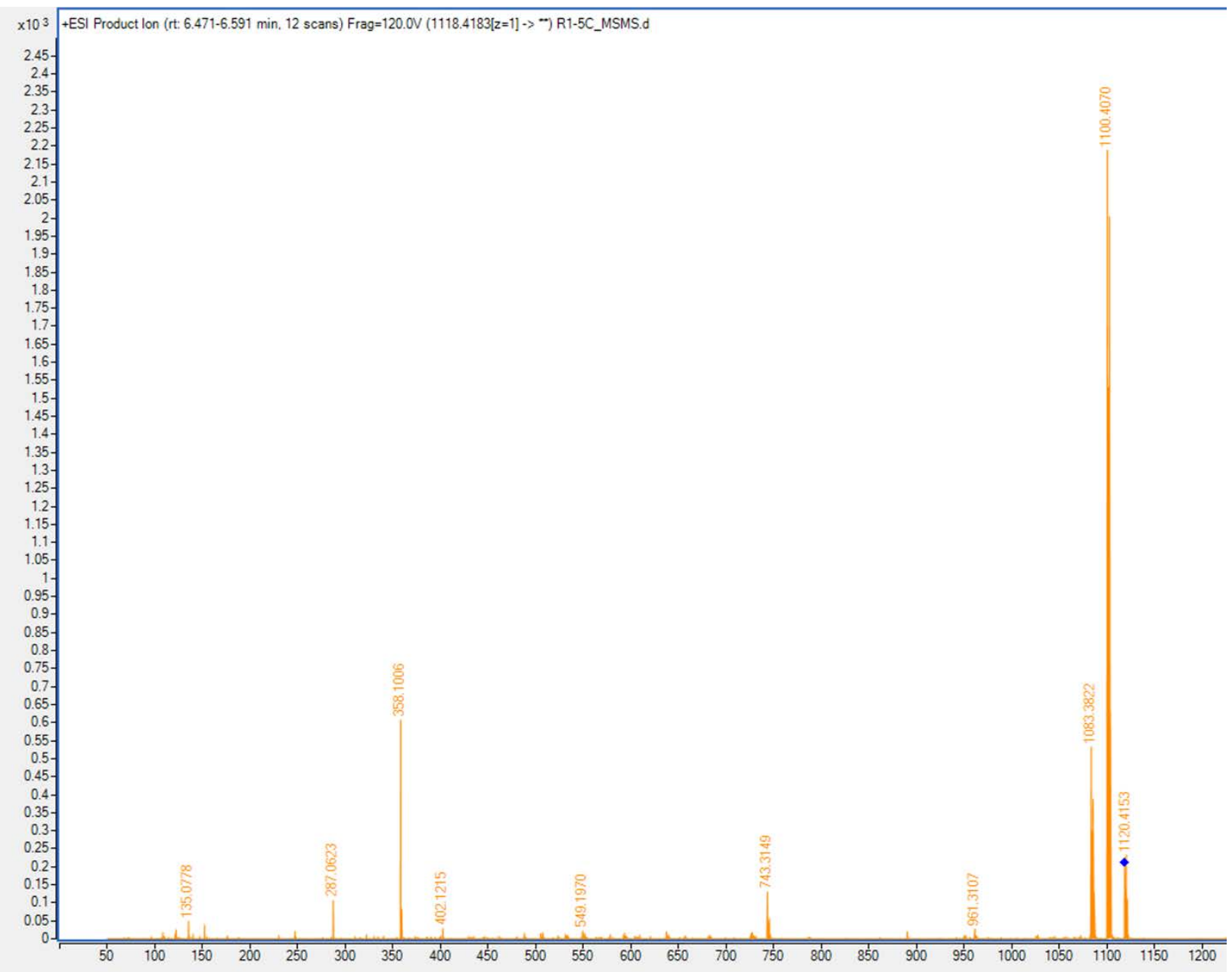

Figure S57: Mass Spectrum (LC-MS/MS) of R1-5C. 